UNIVERSIDADE FEDERAL DE JUIZ DE FORA

INSTITUTO DE CIÊNCIAS EXATAS

MESTRADO NACIONAL PROFISSIONAL EM ENSINO DE FÍSICA

Raquel da Silva Santos Freitas

Uma proposta didática para o ensino de tópicos da

Teoria da Relatividade Restrita

Juiz de Fora 
Raquel da Silva Santos Freitas

Uma proposta didática para o ensino de tópicos da

Teoria da Relatividade Restrita

Dissertação apresentada ao Polo 24 do

Programa de Mestrado Nacional

Profissional em Ensino de Física da Universidade Federal de Juiz de Fora / Instituto Federal Sudeste de Minas Gerais, como requisito parcial à obtenção do título de Mestre em Ensino de Física. Área de concentração: Física na Educação Básica.

Orientador: Prof. Dr. José Roberto Tagliati 
Ficha catalográfica elaborada através do programa de geração automática da Biblioteca Universitária da UFJF, com os dados fornecidos pelo(a) autor(a)

Freitas, Raquel da Silva Santos.

Uma proposta didática para o ensino de tópicos da Teoria da Relatividade Restrita / Raquel da Silva Santos Freitas. -- 2021.

$127 \mathrm{f}$. : il.

Orientador: José Roberto Tagliati

Dissertação (mestrado profissional) - Universidade Federal de Juiz de Fora, Instituto de Ciências Exatas. Programa de Pós-Graduação em Ensino de Física, 2021.

1. Física Moderna . 2. Relatividade Restrita. 3. Sequência Didática. I. Tagliati, José Roberto, orient. II. Título. 


\title{
UMA PROPOSTA DIDÁTICA PARA O ENSINO DE TÓPICOS DA TEORIA DA RELATIVIDADE RESTRITA
}

\author{
Dissertação apresentada ao Polo 24 do \\ Programa de Mestrado Nacional \\ Profissional em Ensino de Física da \\ Universidade Federal de Juiz de Fora I \\ Instituto Federal Sudeste de Minas Gerais \\ como requisito parcial à obtenção do título \\ de Mestre em Ensino de Física. Área de \\ concentração: Física na Educação \\ Básica.
}

Aprovada em 19 de março de 2021

\section{BANCA EXAMINADORA}

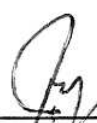

Prof. Dr. José Roberto Tagliati - Orientador

Universidade Federal de Juiz de Fora
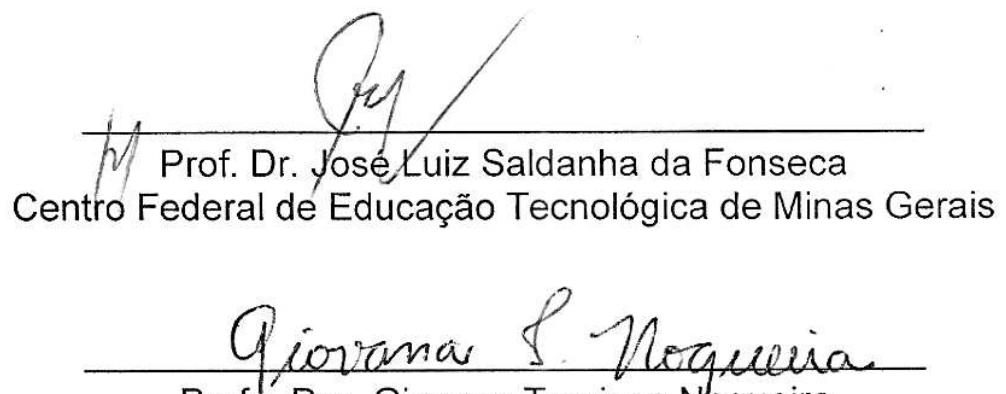

Profa. Dra. Giovana Trevisan Nogueira

Universidade Federal de Juiz de Fora 
Dedico esta, bem como todas as minhas demais conquistas, à minha mãe Dólia (in memoriam). 


\section{AGRADECIMENTOS}

Ao meu orientador, Tagliati, pela paciência, compreensão, competência, apoio, estímulo, e pelas importantes considerações e contribuições a este trabalho.

A Deus, pelo dom da vida e por me dar força e coragem para eu persistir e lutar por essa grande realização.

Ao meu esposo, Jean, que me fez acreditar na realização com sucesso desta importante fase de minha vida.

À minha filha, Alice, por suportar minhas ausências.

À minha familia, em especial a minha mãe, por me fazer entender a importância da educação em minha vida.

Aos professores do programa, pelos ensinamentos transmitidos nas aulas.

Aos colegas e amigos, pelas palavras de incentivo e pela colaboração nos momentos difíceis.

O presente trabalho foi realizado com o apoio da Coordenação de Aperfeiçoamento de Pessoal de Nível Superior - Brasil (CAPES) - Código de Financiamento 001.

E a todos que contribuíram de alguma forma para a realização deste trabalho, o meu respeito e a minha gratidão. 
O importante é jamais parar de questionar; a curiosidade tem sua razão de existir. (Albert Einstein) 


\section{RESUMO}

O rápido desenvolvimento científico e tecnológico pelo qual passa atualmente a humanidade parece despertar um significativo interesse dos estudantes por assuntos da Física relacionados a esses avanços. Muitos desses temas envolvem Física Moderna e Contemporânea (FMC); porém os conteúdos dessa parte da Física geralmente não são contemplados nos planos de ensino, em grande parte das escolas. Face ao exposto, nos propusemos, neste trabalho, elaborar uma proposta de Sequência Didática (SD) visando atrair os estudantes para o conteúdo da FMC, abordando a Teoria da Relatividade Restrita (TRR). Buscamos planejar a SD com o objetivo de tornar o estudo da TRR mais acessível e compreensível, bem como numa percepção mais contextualizada, na perspectiva de se obter traços de uma aprendizagem mais efetiva desse conteúdo. A Sequência Didática foi planejada a partir de um recorte dos conceitos de referencial, espaço e tempo para a abordagem dos conceitos básicos da TRR, como a dilatação temporal, a contração espacial, a relação de equivalência massa-energia, e suas correlações. A aplicação da SD aconteceu ao longo de sete aulas para uma turma do $3^{\circ}$ ano da Educação de Jovens e Adultos (EJA). Utilizou-se como referencial teórico a Teoria da Aprendizagem Significativa de David Ausubel. As atividades propostas foram elaboradas para serem desenvolvidas em pequenos grupos, pretendendo-se com isto que os estudantes construíssem seu conhecimento de forma mais dinâmica e participativa, permitindo um possível melhor desempenho na relação entre ensino e aprendizagem. Como instrumento de coleta de dados, priorizou-se a produção textual dos estudantes, de modo a buscar evidências de uma evolução conceitual mais sólida e reflexiva. Os resultados apontaram para um quadro de relativo sucesso, decorrente da exposição, discussão e constatação de aplicações dos conteúdos científicos abordados, o que nos permite avalizar a indicação e viabilidade do ensino da TRR no ensino básico.

Palavras-chave: Física Moderna, Relatividade Restrita, Sequência Didática. 


\begin{abstract}
The rapid scientific and technological development that is currently undergoing humanity seems to arouse a significant interest of students in matters of Physics related to these advances. Many of these themes involve Modern and Contemporary Physics (FMC); but the contents of this part of Fisica are generally, not included in the teaching plans in most schools. Given the above, the proposal in this work is to elaborate a Didactic Sequence (SD) aiming to attract students to the FMC content, addressing the Theory of Special Relativity (TRR). We seek to plan SD in order to make the study of TRR more accessible and understandable, as well as more contextualized, in the perspective of obtaining traces of a more effective learning of this content. The Didactic Sequence was planned from a cut of the concepts of referential, space and time to approach the basics concepts of TRR, such as temporal dilation, spatial contraction, the mass-energy equivalence relationship, and their correlations. The application of SD took place over seven classes for a class of the 3rd year of Youth and Adult Education (EJA). David Ausubel's Theory of Meaningful Learning was used as a theoretical framework. The proposed activities were designed to be developed in small groups, with the intention that students built their knowledge in a more dynamic and participatory, allowing a better dialogue between teaching and learning. As a data collection instrument, priority was given to the textual production of the students, in order to seek evidence of a conceptual evolution more solid and reflective. The results pointed to a picture of relative success, resulting from the exposure, discussion and verification of applications of the contentes approached, which allows us to guarantee the indication and feasibility of the teaching of TRR in basic education.
\end{abstract}

Keywords: Modern Physics, Special Relativity, Didactic Sequence. 


\section{SUMÁRIO}

1 INTRODUÇÃO _..__.

2 REFERENCIAL TEÓRICO

2.1 A TEORIA DE APRENDIZAGEM SIGNIFICATIVA DE DAVID AUSUBEL 15

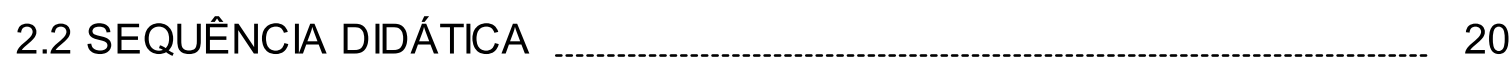

3 TEORIA DA RELATIVIDADE RESTRITA ……

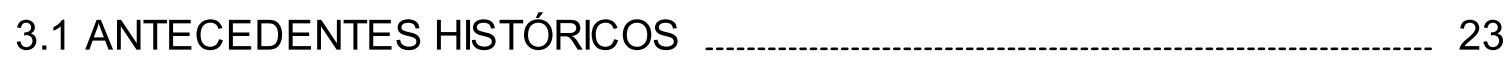

3.2 O ÉTER E O EXPERIMENTO DE MICHELSON E MORLEY _..._.............. 26

3.3 O SURGIMENTO DA TEORIA DA RELATIVIDADE ..................................... 28

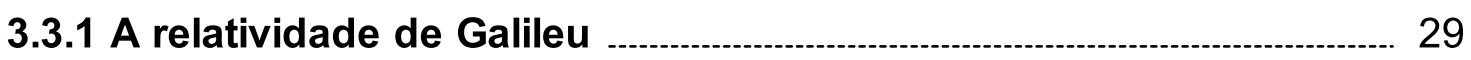

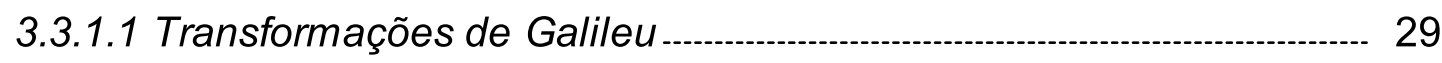

3.3.1.2 Adição galileana de velocidades

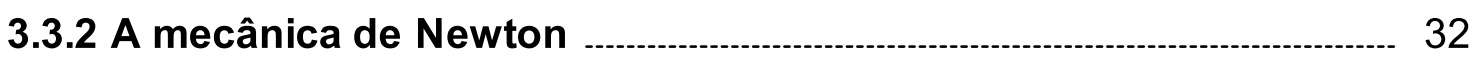

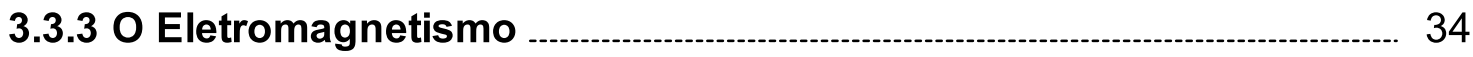

3.3.4 A relatividade de Einstein ..._._._._. 38

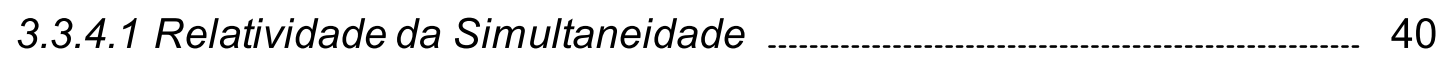

3.3.4.2 As transformações da Relatividade de Einstein _._______._. 41

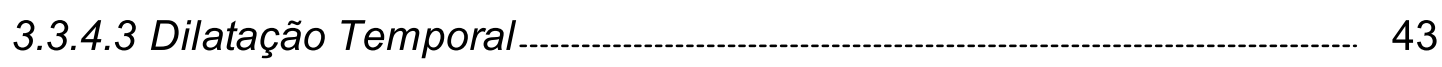

3.3.4.4 Contração do Espaço _..._....................... 44

3.3.5 Equivalência Massa-Energia _._____ 45

4 PROCEDIMENTOS METODOLÓGICOS

4.1 AS CARACTERISTICAS DA PESQUISA QUALITATIVA ...................... 49

4.2 ESTRATÉGIAS DESENVOLVIDAS NA PESQUISA E ESTRUTURA DA SEQUÊNCIA DIDÁTICA

5 A APLICAÇÃO DA SEQUÊNCIA DIDÁTICA

6 ANÁLISE DOS RESULTADOS ….......... 59

6.1 AULA 1 - QUESTIONÁRIO INVESTIGATIVO

6.2 AULA 2 - ESPAÇO

6.3 AULA 3 - TEMPO 
6.4 AULA 4 - POSTULADOS DA TEORIA DA RELATIVIDADE RESTRITA ... 81

6.5 AULA 5 - DILATAÇÃO DO TEMPO E CONTRAÇÃO DO ESPAÇO _....... 81

6.6 AULA 6 - RELAÇÃO DE EQUNALÊNCIA MASSA-ENERGIA ................ 82

6.7 AULA 7 - AVALIAÇÃO

7 CONSIDERAÇÕES FINAIS

REFERÊNCIAS

APÊNDICE A - Produto Educacional _.__ 96

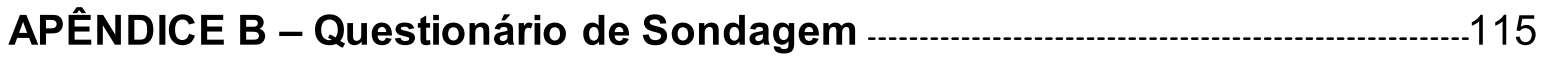

APÊNDICE C - Localização no Espaço: Coordenadas

APÊNDICE D - Questionário: Música Semana que vem

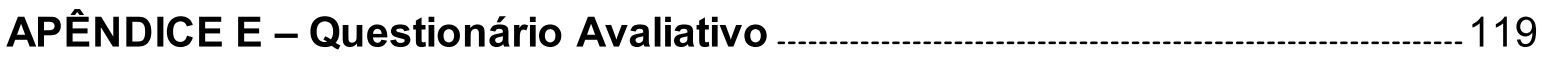

ANEXO A - Música Semana Que Vem - Pitty

ANEXO B - Seu celular mastiga fórmulas de Einstein para o Waze

funcionar

ANEXO C - Infográfico Funcionamento do GPS

ANEXO D - Massa e Energia

ANEXO E - A Energia Nuclear e a Bomba Atômica 


\section{INTRODUÇÃO}

Ao longo da história da humanidade o homem sempre buscou entender melhor o meio no qual ele vivia e a dinâmica de sua vida. Pela necessidade de sobrevivência e por meio da observação dos fenômenos da Natureza, evoluímos e nos tornamos uma sociedade moderna e desenvolvida.

Presenciamos nos últimos anos significativos avanços tecnológicos e científicos, e a Física, como parte da ciência, tem feito importantes contribuições, tanto na área de pesquisa como na criação de novas tecnologias. Para alcançar tais avanços, foi fundamental o desenvolvimento da própria Física como, por exemplo, as teorias da Relatividade e da Física Quântica, dando início à Física Moderna e Contemporânea, no final do século XIX.

$\mathrm{Na}$ sociedade atual, grande parte dos recursos tecnológicos existentes fazem uso de conceitos relacionados à Física Moderna e Contemporânea (FMC). A medicina faz uso de raios laser para cirurgias, e exames são realizados com aparelhos de ressonância magnética. Também utilizamos o telefone celular, o GPS, computadores, etc., que são recursos cada vez mais presentes em nosso cotidiano, mas que grande parte dos usuários não consegue entender a base ou a fundamentação científica de seu funcionamento. Diante de uma realidade que envolve uma ciência tão presente e ao mesmo tempo tão desconhecida, não se pode mais conceber o ensino de Física, em particular no nível médio, sem que se aborde a Física Moderna e Contemporânea. É necessário proporcionar ao aluno conceitos e atitudes que sirvam de instrumentos na interpretação do mundo científico e tecnológico em que vivemos, para sua capacitação como indivíduo e cidadão.

De acordo com os Parâmetros Curriculares Nacionais para o Ensino Médio (BRASIL,1999), o ensino de Física nas escolas deve levar à formação de um cidadão contemporâneo, e que permita ao aluno perceber e lidar com os fenômenos naturais e tecnológicos presentes no cotidiano, a partir de princípios, leis, modelos ou relações matemáticas.

O ensino de Física, na grande maioria das escolas brasileiras de Ensino Médio, tem sido alvo de muitas críticas. Há ênfase na memorização e aplicação direta de fórmulas, com resoluções de problemas matemáticos que, por si só, não permitem aos estudantes estabelecerem relações entre os conceitos e os 
fenômenos envolvidos na produção do conhecimento. Também, a carência de uma adequada contextualização desta ciência tem contribuído para que os alunos considerem a Física como chata, difícil e distante da realidade.

Além de estratégias e metodologias de ensino em geral pouco eficazes, a divisão tradicional dos conteúdos (Mecânica, Física Térmica, Ondas, Óptica e Eletromagnetismo) também tem sido questionada. O ensino de tais conteúdos, voltados para temas, teorias, problemas e assuntos que, embora englobando todos os campos da Física Clássica, parece não fazer qualquer sentido para os estudantes. Apesar de abordarem assuntos relevantes e muito pertinentes, falham no sentido de pouco fazer ver sua relação para as situações e problemas enfrentados no cotidiano. De um modo geral, os conteúdos de Física Moderna, não são abordados no nível básico, menos ainda os desenvolvimentos mais recentes da Física Contemporânea (TERRAZZAN, 1992).

Por conta destes e outros aspectos aqui expostos, a necessidade de uma reformulação no currículo de Física do Ensino Médio, a fim de acrescentar os avanços obtidos pela ciência do século $X X$ tem sido muito discutida. Podemos citar alguns autores brasileiros (OSTERMANN, 1999; ARRUDA e VILLANI, 1994; TERRAZAN, 1992) que abordam estas questões e propõem uma reestruturação curricular visando à inserção de tópicos de Física Moderna e Contemporânea.
A influência crescente dos conteúdos de Física Moderna e Contemporânea para o entendimento do mundo criado pelo homem atual, bem como a inserção consciente, participativa e modificadora do cidadão neste mesmo mundo define, por si só, a necessidade de debatermos e estabelecermos as formas de abordar tais conteúdos na escola de $2^{\circ}$ grau. (TERRAZZAN, 1992, p.210)

Diante da realidade em nossas salas de aulas, faz-se necessário dar ao ensino de Física novas dimensões. Os alunos demonstram interesse pela temática da FMC, como a Teoria da Relatividade e a Física Quântica; tais temas aguçam a curiosidade e despertam questionamentos de todo tipo, em função de muitas observações, manifestações e aplicações afins. Segundo Wolff \& Mors (2005, p.3): "Sem uma compreensão do que é tratado em Física Moderna, a quase totalidade do mundo à nossa volta se torna mágica, fora de nossa compreensão e controle." Portanto, é preciso implementar ferramentas cognitivas e conhecimentos que auxiliem na interpretação deste mundo tecnológico e científico, promovendo assim um conhecimento contextualizado. 
Desde que comecei a dar aulas de Física no Ensino Médio, em 2008, na cidade de Viçosa, a prática docente revelou-se um tanto quanto desafiadora. Recém-formada, cheia de planos e ânimo, comecei a vivenciar que a disciplina que aos meus olhos era a mais fascinante, para a grande maioria dos alunos era uma das mais difíceis e entediantes.

Ao longo desses 12 anos de sala de aula, sempre busquei oferecer aos meus alunos um ensino de qualidade, mas, por diversas vezes me deparei com dificuldades quase que intransponíveis, tais como, a carga horária semanal reduzida, as deficiências em conhecimentos prévios, o desinteresse e a falta de compreensão do conteúdo, entre outras. Tais dificuldades sempre me fizeram pensar em como motivar os alunos a aprender Física.

A vivência em sala de aula me permitiu constatar que quando ensinamos Física de uma "forma diferente" usando, por exemplo, um pequeno experimento de baixo custo, ou apresentando um vídeo ou até mesmo um texto que mostra a aplicação da Física no cotidiano, os alunos se sentem mais estimulados a estudar, pois, conseguem atribuir um significado àquele conteúdo e estabelecer conexões entre o que é ensinado e a sua realidade.

Então, com o intuito de me qualificar e atuar com mais consciência no sentido de ensinar uma Física mais atual, contextualizada e interessante para os alunos, ingressei no Mestrado Profissional em Ensino de Física (MNPEF) considerando que os conhecimentos transmitidos e a formação oferecida proporcionariam uma significativa melhora da minha prática docente.

Assim, considerando que a curiosidade e os questionamentos são ferramentas básicas para um melhor quadro de aprendizagem, partimos para a elaboração de uma Sequência Didática (SD) abordando um tema da FMC. A proposta em pauta, segundo nossa perspectiva, visa contribuir para uma aprendizagem mais eficaz e contextualizada, envolvendo ideias da Teoria da Relatividade Restrita (TRR). Dessa forma, a SD foi planejada com o objetivo de tornar o estudo da Teoria da Relatividade Restrita mais acessível e compreensível aos alunos do Ensino Médio, empregando uma estratégia que visa tornar o estudante protagonista no processo ensino-aprendizagem.

A inserção da TRR se funda basicamente em três aspectos: a mudança de padrão de raciocínio e interpretação da realidade aliada à abstração e sofisticação do pensamento, graças à concepção de tempo como uma quarta dimensão; a possibilidade 
dessa teoria servir de porta de entrada para outros tópicos da FMC e, finalmente, pela necessidade de abordagem de um tema tão presente na sociedade através da divulgação científica. (RODRIGUES, 2001, p.23)

Nesse sentido, as atividades propostas nessa sequência didática foram elaboradas para serem desenvolvidas em pequenos grupos, pretendendo-se com isto, que os estudantes construam seu conhecimento de forma mais dinâmica e participativa. A intenção é proporcionar condições para uma aprendizagem onde o aluno não seja apenas um sujeito passivo, que apenas recebe os conteúdos e os absorve de forma apática e sem sentido. Em nossa proposta, a ideia é inicialmente fazer com que o aluno expresse suas impressões sobre o tema e, a partir dessas informações e com o auxilio das ferramentas pedagógicas utilizadas, consiga agregar e desenvolver novos conhecimentos. Essa participação mais ativa no processo de aprendizagem pode despertar nos alunos o interesse pelo estudo da Física e desenvolver uma melhor compreensão dos conteúdos estudados.

Esta dissertação está organizada em sete capítulos. A fundamentação teórica para a construção da proposta é descrita no segundo capítulo, onde os pressupostos da Teoria da Aprendizagem Significativa de David Ausubel e o conceito de sequência didática são detalhados. No capítulo três, temos um breve histórico do surgimento da relatividade e a descrição conceitual dos tópicos de TRR contemplados na sequência didática. No capítulo quatro, apresentamos a metodologia da sequência didática. No capítulo cinco, a descrição da aplicação da SD. O capítulo seis traz os dados coletados durante a aplicação da sequência e a análise dos resultados. No capítulo sete, fazemos as considerações finais acerca do trabalho desenvolvido e, em seguida, as referências bibliográficas. Por último, nos apêndices, trazemos o produto educacional elaborado como parte da construção deste trabalho. 


\title{
2 REFERENCIAL TEÓRICO
}

O presente trabalho tem como embasamento teórico a teoria de aprendizagem significativa de David Ausubel. ${ }^{1}$

David Ausubel, como um representante do cognitivismo (MOREIRA, 1995), descreve uma explicação teórica do processo de aprendizagem com foco no trabalho pedagógico em sala de aula. O cognitivismo se preocupa com o processo de compreensão, transformação, armazenamento e uso da informação envolvida na cognição (MOREIRA; MASINI, 1982).

Sua teoria prioriza a aprendizagem cognitiva, sendo esta, o resultado do armazenamento organizado de informações na mente do ser que aprende. Todas as informações e o conteúdo total e organizado de ideias de um dado indivíduo é chamado de estrutura cognitiva.

Para Ausubel, a aprendizagem consiste na "ampliação" da estrutura cognitiva, através da incorporação de novas ideias (GHEDIN, 2012). Dependendo do tipo de relacionamento que se tem entre as ideias já existentes nesta estrutura e as novas que se estão internalizando, pode ocorrer um aprendizado que varia do mecânico ao significativo.

\subsection{A TEORIA DE APRENDIZAGEM SIGNIFICATNA DE DAVID AUSUBEL}

A ideia central da teoria de Ausubel é a da aprendizagem significativa, um processo em que ocorre a interação cognitiva entre o novo conhecimento e o conhecimento preexistente na estrutura cognitiva do aprendiz.

\begin{abstract}
Aprendizagem significativa é aquela em que ideias expressas simbolicamente interagem de maneira substantiva e não-arbitrária com aquilo que o aprendiz já sabe. Substantiva quer dizer nãoliteral, não ao pé-da-letra, e não-arbitrária significa que a interação não é com qualquer ideia prévia, mas sim com algum conhecimento especificamente relevante já existente na estrutura cognitiva do sujeito que aprende. (MOREIRA, 2012, p.2)
\end{abstract}

Esse "conhecimento especificamente relevante", Ausubel define como ideia âncora ou subsunçor.

\footnotetext{
${ }^{1}$ David Ausubel (1918-2008) foi um médico, psiquiatra, psicólogo, educador e pesquisador americano que trabalhou em áreas como a psicologia étnica e o campo da aprendizagem. Filho de judeus cresceu insatisfeito com a educação que recebeu. Dizia que a educação é violenta e a escola, uma prisão. Dedicou-se à psicologia educacional e tornou-se um representante do cognitivismo ao propor a teoria da aprendizagem significativa.
} 
Em termos simples, subsunçor é o nome que dá a um conhecimento específico, existente na estrutura de conhecimentos do indivíduo, que permite dar significado a um novo conhecimento que lhe é apresentado ou por ele descoberto. (MOREIRA, 2012, p.2)

Dessa forma, as características básicas da aprendizagem significativa são: 1) a não-arbitrariedade, isto é, o conteúdo a ser aprendido se relaciona de maneira lógica com conhecimentos anteriores, ou seja, se ancoram em conhecimentos especificamente relevantes (subsunçores) preexistentes na estrutura cognitiva; 2) a substantividade, que significa que, o que é incorporado à estrutura cognitiva é o significado do novo conhecimento e não as palavras ou símbolos usados para expressá-los.

Portanto, quando uma nova informação "ancora-se" em conceitos relevantes pré-existentes na estrutura cognitiva e adquirem significado para o indivíduo, a aprendizagem é dita significativa.

Para Ausubel, os conhecimentos prévios dos estudantes são fundamentais para sua aprendizagem, como pode-se perceber na citação a seguir.

Se tivesse que reduzir toda a psicologia educacional a um só princípio, diria o seguinte: o fator isolado mais importante que influencia a aprendizagem é aquilo que o aprendiz já sabe. (MOREIRA e OSTERMANN, 1999, p.45 apud OSTERMANN \& CAVALCANTI, 2011, p.35).

Assim, para Ausubel, o aluno aprende a partir do que já sabe. É a estrutura cognitiva, ou seja, os conhecimentos prévios hierarquicamente organizados, que influenciam a aprendizagem significativa de novos conhecimentos.

De acordo com Moreira e Masini (1986), à medida que ocorre a aprendizagem significativa, conceitos são desenvolvidos, elaborados e diferenciados em decorrência de sucessivas interações, o que leva à diferenciação progressiva e à reconciliação integrativa.

Diferenciação progressiva ocorre quando, sucessivamente, um subsunçor é modificado a partir da introdução novas informações.

Através de sucessivas interações um dado subsunçor vai progressivamente, adquirindo novos significados, vai ficando mais rico, mais refinado, mais, diferenciado, e mais capaz de servir de ancoradouro para novas aprendizagens significativas. (MOREIRA, 2012, p.6) 
Reconciliação integrativa ou integradora é o processo de estabelecer relações entre conceitos já existentes na estrutura cognitiva, e os subsunçores se organizam e adquirem novos significados.

A diferenciação progressiva e a reconciliação integrativa são processos simultâneos e necessários à construção cognitiva. Quando se aprende de maneira significativa, o aprendiz vai diferenciando progressivamente e, ao mesmo tempo, reconciliando, integrativamente, os novos conhecimentos, em interação com aqueles já existentes.

Existem algumas condições para que a aprendizagem significativa ocorra, como descrito a seguir:

1) o material de aprendizagem deve ser potencialmente significativo, ou seja, 0 material de aprendizagem (livros, aulas, etc.) tem que ter significado lógico e ser relacionável ou incorporável à estrutura cognitiva do aprendiz, de maneira nãoarbitrária e não-literal; dessa forma o aprendiz deve ter subsunçores adequados para que esse material possa ser relacionado.

É importante enfatizar aqui que o material só pode ser potencialmente significativo, não significativo: não existe livro significativo, nem aula significativa, nem problema significativo,..., pois o significado está nas pessoas, não nos materiais. É o aluno que atribui significados aos materiais de aprendizagem e os significados atribuídos podem não ser aqueles aceitos no contexto da matéria de ensino. (MOREIRA, 2012, p.8)

2) o aprendiz deve apresentar uma predisposição para aprender, ou seja, o aluno tem que manifestar uma disposição para relacionar, de maneira não-arbitrária e não-literal, à sua estrutura cognitiva, os significados que capta dos materiais potencialmente significativos. Não se trata de motivação ou de gostar da matéria, o aprendiz não pode ter a intenção de memorizar ou de decorar o material.

Segundo Ausubel, quando uma das duas condições não for satisfeita, ocorrerá uma aprendizagem mecânica.

Ausubel define aprendizagem mecânica como aquela com pouca ou nenhuma interação com a estrutura cognitiva dos estudantes. Nesse caso, a nova informação é armazenada de maneira arbitrária e não há interação entre a nova informação e aquela já armazenada. Em uma linguagem popular, a aprendizagem mecânica é a conhecida "decoreba", que serve para as provas e é esquecida logo após. 
Para Ausubel, a aprendizagem significativa e a aprendizagem mecânica não constituem uma dicotomia: elas se complementam ao longo de um mesmo contínuo, pois a segunda pode levar à primeira.

De acordo com Moreira (2012), há uma "zona cinza” entre elas.

Figura 1 - Visão esquemática do contínuo entre aprendizagem significativa e aprendizagem mecânica

APRENDIZAGEM

MECÂNICA

Ensino Potencialmente Significativo

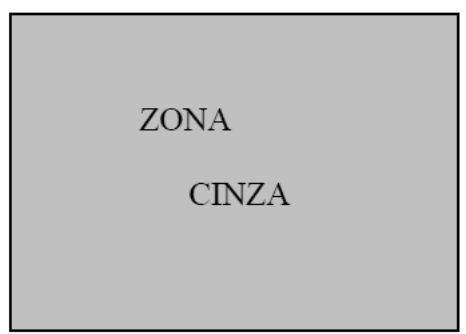

Armazenamento literal, arbitrário, sem significado; não requer compreensão, resulta em aplicação mecânica a situações conhecidas
APRENDIZAGEM

SIGNIFICATIVA
Incorporação substantiva, não arbitrária, com significado; implica compreensão,

transferência, capacidade de explicar, descrever, enfrentar situações novas.

Fonte: O que é afinal a aprendizagem significativa? (MOREIRA, 2012, p.12)

A existência desse contínuo entre aprendizagem significativa e mecânica sugere que, na prática, grande parte da aprendizagem ocorre na zona intermediária desse contínuo e que um ensino potencialmente significativo pode facilitar a "passagem" do aluno por essa zona cinza.

Considerando que a aprendizagem mecânica pode ocorrer quando um indivíduo adquire informações em uma área completamente nova para ele, Ausubel propõe o uso de organizadores prévios, que são materiais introdutórios apresentados antes do material a ser aprendido e que podem ser usados para ativar os subsunçores ou quando eles não existem.

O organizador prévio não se trata de um resumo, ou de uma visão geral, pois é apresentado em um nível mais alto de abstração, generalidade e inclusividade. Pode ser uma pergunta, uma situação-problema, um texto, mas a condição é que preceda a apresentação do material de aprendizagem e que seja mais abrangente. 
A principal função dos organizadores prévios é servir de ponte entre o que o estudante sabe e o que ele deve aprender, facilitando uma aprendizagem significativa.

No cotidiano escolar geralmente as avaliações aplicadas cobram a resolução de exercícios, a definição de um determinado conceito, e classificam as repostas em certas ou erradas. Geralmente, esse tipo de avaliação promove a aprendizagem mecânica, pois não entra na questão do significado, da compreensão. O aluno pode saber definir e expressar corretamente um determinado conceito, mas, isso não implica que ele o tenha entendido.

Ausubel propõe que a avaliação da aprendizagem significativa deve avaliar a compreensão, a captação de significados, a capacidade de transferências de conhecimentos a situações não conhecidas, não rotineiras. Para ele a melhor maneira de evitar a simulação da aprendizagem significativa é propor ao aprendiz uma situação nova, não familiar, que requeira máxima transformação do conhecimento adquirido. $\mathrm{O}$ aluno deve expressar verbalmente o que aprendeu.

De acordo com Moreira,

Portanto, a avaliação da aprendizagem significativa deve ser predominantemente formativa e recursiva. É necessário buscar evidências de aprendizagem significativa, ao invés de querer determinar se ocorreu ou não. É importante a recursividade, ou seja, permitir que o aprendiz refaça mais de uma vez se for o caso, as tarefas de aprendizagem. É importante que ele ou ela externalize os significados que está captando, que explique, justifique, suas respostas. (MOREIRA, 2012, p.24)

A avaliação da aprendizagem significativa não é fácil, pois implica em uma nova postura do professor. Qualquer instrumento, técnica ou método, até mesmo as novas metodologias e as tecnologias de informação e comunicação que utilizarem a estratégia "copiar, memorizar e reproduzir" estarão estimulando a aprendizagem mecânica.

É importante salientar que em todo o processo da aprendizagem significativa o aluno é o protagonista, mas cabe ao professor oferecer as condições para que isso ocorra. Ostermann \& Cavalcanti descrevem:

Uma abordagem ausubeliana ao ensino da Física envolve o professor em pelo menos quatro tarefas fundamentais. A primeira seria determinar a estrutura conceitual e proposicional de matéria de ensino, organizando os conceitos e princípios hierarquicamente. Uma segunda tarefa seria identificar quais os subsunçores relevantes à aprendizagem do conteúdo a ser 
ensinado, que o aluno deveria ter na sua estrutura cognitiva para poder aprender significativamente. Outra etapa importante seria determinar dentre os subsunçores relevantes, quais os que estão disponíveis na estrutura cognitiva do aluno. Finalmente, ensinar utilizando recursos e princípios que facilitem a assimilação da estrutura da matéria de ensino por parte do aluno e organização de suas próprias estruturas cognitivas nessa área de conhecimentos, através da aquisição de significados claros, estáveis e transferíveis. (OSTERMANN \& CAVALCANTI, 2011, p.35 e 36)

Dentro do âmbito das teorias de aprendizagem, a aprendizagem significativa de Ausubel (1963, p.58 apud MOREIRA, CABALLERO \& RODRÍGUEZ, 1997), como ele mesmo considera, "é um mecanismo humano de excelência, para adquirir e armazenar uma vasta quantidade de ideias e informações, representadas em qualquer campo de conhecimento".

A aprendizagem significativa não é aquela que o aprendiz nunca esquece. Segundo Ausubel, o esquecimento é uma consequência natural da aprendizagem, mas, na aprendizagem significativa o conhecimento fica esquecido dentro do subsunçor. Dessa forma, espera-se que o conteúdo da proposta didática aqui apresentada possua grande potencialidade, permitindo que dentro de alguns anos ainda estejam presentes as concepções de Teoria da Relatividade Restrita, mesmo que de forma residual, na estrutura mental desses estudantes.

\subsection{SEQUÊNCIA DIDÁTICA}

Escolher de que maneira e quais conteúdos abordar são questões fundamentais para que o aluno tenha uma aprendizagem significativa. Nossa proposta, visando alcançar maiores possibilidades de uma aprendizagem mais efetiva, é a elaboração de uma Sequência Didática (SD). A Sequência Didática lembra um plano de aula, entretanto é mais ampla, pois contempla uma sequência de algumas aulas e várias estratégias de ensino. O autor Zabala define Sequência Didática como,

um conjunto de atividades ordenadas, estruturadas e articuladas para a realização de certos objetivos educacionais, que têm um princípio e um fim conhecidos tanto pelos professores como pelos alunos. (ZABALA, 1998, p.18) 
Também Kobashigawa et al. (2008) definem sequência didática como um conjunto de atividades, estratégias e intervenções planejadas, etapa por etapa, pelo docente, para que o entendimento do conteúdo ou tema proposto seja alcançado pelos discentes.

De acordo com Oliveira, sequência didática é definida como:

um procedimento simples que compreende um conjunto de atividades conectadas entre si, e prescinde de um planejamento para delimitação de cada etapa e/ou atividade para trabalhar os conteúdos disciplinares de forma integrada para uma melhor dinâmica no processo ensino-aprendizagem. (OLIVEIRA, 2013, p.39)

Analisando as definições dos autores citados, uma sequência didática deve ser desenvolvida na perspectiva do ensino de conteúdos por meio de atividades devidamente planejadas, relacionadas entre si e sequenciadas, organizadas com objetivos bem definidos e esclarecidos para professores e alunos, que contribuirão para a aprendizagem e construção do conhecimento. Desta maneira, uma sequência didática deve ser organizada de acordo com os objetivos que o professor quer alcançar para a aprendizagem de seus alunos, envolvendo diversas atividades de aprendizagem e avaliação.

No Brasil, o termo sequência didática surgiu nos documentos oficiais dos Parâmetros Curriculares Nacionais (PCNs), a partir de 1998, como "projetos" e "atividades sequenciadas" usadas no estudo da Língua Portuguesa, enfatizando a importância do ensino dos gêneros textuais em sala de aula. Atualmente, as sequências didáticas estão presentes no estudo de todos os conteúdos dos diversos componentes curriculares da escola básica.

Zabala (1998) enfatiza que durante a elaboração da sequência didática, o professor deve se perguntar se existem atividades:

a) que nos permitam determinar os conhecimentos prévios que cada aluno tem em relação aos novos conteúdos de aprendizagem?

b) cujos conteúdos são propostos de forma que sejam significativos e funcionais para os meninos e meninas?

c) que possamos inferir que são adequadas ao nível de desenvolvimento de cada aluno?

d) que representem um desafio alcançável para o aluno, quer dizer, que levam em conta suas competências atuais as façam avançar com a ajuda necessária; portanto, que permitam criar zonas de desenvolvimento proximal e intervir? 
e) que provoquem um conflito cognitivo e promovam a atividade mental do aluno necessária para que estabeleça relações entre os novos conteúdos e os conhecimentos prévios?

f) que promovam uma atitude favorável, quer dizer, que sejam motivadoras em relação à aprendizagem de novos conteúdos?

g) que estimulem a autoestima e o autoconhecimento em relação às aprendizagens que se propõem, quer dizer, que o aluno possa sentir que em certo grau aprendeu, que seu esforço valeu a pena? h) que ajudem o aluno a adquirir habilidades relacionadas com o aprender a aprender, que lhe permitam ser cada vez mais autônomo em suas aprendizagens? (ZABALA, 1998, p.63-64)

As Sequências Didáticas (SD) contribuem para a consolidação de conhecimentos que estão em fase de construção e permitem que, progressivamente, novas aquisições sejam possíveis. Ou seja, a organização dessas atividades prevê uma progressão modular, a partir do levantamento dos conhecimentos que os alunos já possuem sobre um determinado assunto, conforme Brasil (2012, p.20).

Dessa forma, espera-se que com o uso das sequências didáticas o trabalho docente possa ser aprimorado, por meio da observação do processo de desenvolvimento da SD e da interação entre todos os envolvidos. Almeja-se também que favoreça a interdisciplinaridade e contribua para a aprendizagem significativa, levando os estudantes a realizarem uma reflexão sobre o ensino proposto, objetivando que os conhecimentos adquiridos sejam levados para a vida e não somente considerado no momento da avaliação.

Os conceitos apresentados neste capítulo orientaram a construção da sequência didática apresentada nesta dissertação. A SD tem como assunto norteador tópicos da Teoria da Relatividade Restrita que serão analisados no próximo capítulo. 


\section{TEORIA DA RELATIVIDADE RESTRITA}

\subsection{ANTECEDENTES HISTÓRICOS}

No final do século $X I X$ e início do século $X X$ pairava sobre a comunidade científica uma sensação de que não havia mais nada de novo para ser descoberto em Física, todos os fenômenos naturais, com poucas exceções, eram explicados com as teorias existentes.

Grandes sucessos científicos que ocorreram neste período, tais como: o desenvolvimento da Termodinâmica que permitiu o aperfeiçoamento de máquinas térmicas e culminou na primeira Revolução Industrial; a unificação da Eletricidade e do Magnetismo e as inúmeras aplicações práticas advindas do Eletromagnetismo, como a geração de energia elétrica; a constatação triunfal para a Mecânica Clássica da existência de um novo planeta, Netuno; os fenômenos de difração e interferência da luz que propunham a natureza ondulatória da luz em vez do caráter corpuscular, e outros avanços científicos davam à Física uma crença de ciência já saturada.

Dessa forma, ao final do século XIX as áreas da Física que chamamos de "Física Clássica" e que compreendem a mecânica, a termodinâmica, a óptica e o eletromagnetismo já tinham atingindo um alto nível de desenvolvimento, perceptível através da consolidação das teorias existentes, dos novos fenômenos descobertos e das novas leis estabelecidas. A fala de Albert A. Michelson (18521931) ao proferir uma palestra em 1894, expressa o momento vivido:

Embora nunca seja seguro afirmar que o futuro da física não possui maravilhas ocultas ainda mais estonteantes do que as do passado, parece provável que a maioria dos grandes princípios básicos já tenham sido firmemente estabelecidos e que os avanços futuros ocorram apenas na aplicação rigorosa desses princípios a todos os fenômenos que apareçam... Um físico eminente comentou que as futuras verdades da física devem ser procuradas na sexta casa decimal. (MICHELSON apud PEDUZZ, 2005, p.99)

Entretanto, existiam ainda alguns conflitos e inconsistências entre as previsões teóricas e as evidências experimentais de algumas teorias das áreas acima citadas. No ano de 1900, o físico Willian Thomson (1824-1907), conhecido como Lord Kelvin, proferiu um discurso em uma conferência onde mencionou que ainda existiam duas questões a serem resolvidas pela Física. As "duas nuvens" no 
céu azul da Física eram os resultados negativos do experimento de Michelson e Morley para verificação da velocidade da Terra em relação ao éter e a dificuldade em explicar a distribuição de energia na radiação de um corpo aquecido.

A beleza e claridade da teoria dinâmica, que coloca calor e luz como modos de movimento, está presentemente obscurecida por duas nuvens. I. A primeira apareceu com a teoria ondulatória da luz, desenvolvida por Fresnel e o Dr. Thomas Young; envolvendo a questão de como pode a Terra mover-se através de um sólido elástico, como o é essencialmente o éter luminífero? II. A segunda é a doutrina de Maxwell-Boltzmann sobre a equipartição de energia. (KELVIN apud SCHULZ, 2007, p.510)

O otimismo de Lord Kelvin, ao resumir em apenas duas nuvens os problemas que a Física enfrentava, era compartilhado por muitos físicos da época. Entretanto, existiam ainda muitos problemas na física no final do século $X I X$, com fenômenos inexplicados e problemas teóricos pendentes.

Havia, na verdade, um enorme número de nuvens no horizonte da Física, uma verdadeira tempestade que ameaçava derrubar tudo. Era o otimismo, ou talvez o orgulho de saber muito, que impedia a maioria dos físicos de perceber como a situação era grave. (MARTINS, 2001, p.4).

Contudo, os dois problemas escolhidos por Kelvin foram muito precisos e a busca pela 'resolução' deu início ao desenvolvimento da Física Moderna.

Deve-se admitir que Lord Kelvin soube escolher bem suas "nuvens", uma vez que esses foram precisamente os dois problemas que eventualmente produziram as mudanças revolucionárias na estrutura conceitual da física que ocorreram no século vinte. (BOHM apud PEDUZZI, 2005, p.101)

A postura tranquila de Lord Kelvin e dos demais físicos retrata o que o epistemólogo Thomas S. Kuhn (1922 - 1996) chama de período de ciência normal. O termo ciência normal é utilizado por Kuhn para designar um período onde há adesão da comunidade científica ao paradigma dominante (a física clássica), e este paradigma é utilizado para resolver os problemas que existem (OSTERMANN, 1996). De acordo com Kuhn, a ciência evolui quando os períodos de ciência normal são interrompidos pelas crises provocadas por problemas experimentais e/ou teóricos. Em resposta à crise surge uma revolução científica que provoca uma mudança conceitual e estabelece um novo paradigma. Portanto, de acordo com os conceitos de Kuhn, podemos interpretar que os problemas experimentais e teóricos ainda sem solução dentro da Física Clássica geraram 
uma crise, que culminou em uma revolução científica que deu início à Física Moderna (Mecânica Quântica e Teoria da Relatividade).

A Física Moderna nasceu das inconsistências e dos conflitos gerados por problemas experimentais e/ou teóricos tais como, os apresentados por Kelvin. Esses problemas surgiam nas 'fronteiras' das áreas da Física Clássica.

Nas fronteiras entre estas áreas encontravam-se aqueles problemas nos quais diferentes conceitos básicos se sobrepunham. Só através do estudo destes problemas de fronteira é que se poderia saber até que ponto os diferentes conceitos das três diferentes áreas eram coerentes entre si. Por outro lado, o descobrimento de incoerências conceituais quando associado a um problema concreto funciona, tipicamente, como motor de inovações científicas, pois toda tentativa de resolver um problema concreto obriga concomitantemente a que repensemos os conceitos envolvidos e pode, pela transformação destes conceitos ou de teorias inteiras, abrir novos horizontes. Por este motivo os problemas de fronteira da física clássica puderam se tornar os pontos de partida para a superação destas mesmas fronteiras. (RENN, 2004, p.30).

A figura 2 esquematiza a interseção entre os problemas nas fronteiras da física clássica e as respectivas revoluções provocadas pela inserção das teorias modernas

Figura 2 - Fronteiras da Física Clássica

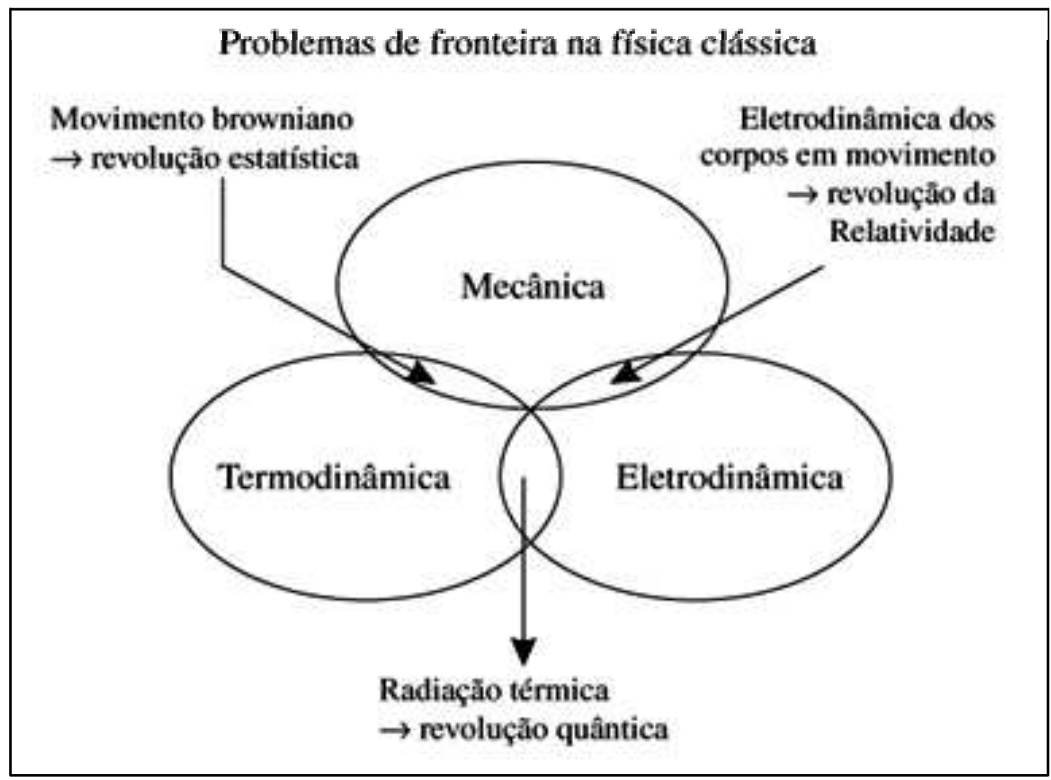

Fonte: Renn, 2004. 
A transição das teorias clássicas para as teorias modernas não aconteceu de forma abrupta. Todas as mudanças conceituais importantes da física no início do século XX foram desencadeadas pelos trabalhos desenvolvidos por vários físicos, visto que, uma descoberta leva a outra. Dessa forma, muitos físicos contribuíram para a elaboração das teorias que compõem a Física Moderna. A seguir, descreveremos as motivações que deram origem à Teoria da Relatividade.

\subsection{O ÉTER E O EXPERIMENTO DE MICHELSON E MORLEY}

A primeira nuvem citada por Kelvin era o problema da detecção do éter, meio hipotético pelo qual se propagavam as ondas luminosas. A ideia de o espaço ser preenchido por um fluido puro e transparente vem da época dos gregos. Aristóteles acreditava que o éter era uma substância pura, transparente e inalterável que preenchia o espaço. Em 1678, Huygens, em seus estudos sobre a teoria ondulatória da luz, usou o comportamento das ondas sonoras para definir o éter. Huygens sabia que as ondas sonoras não se propagam no vácuo, mas as luminosas sim. Ele acreditava que da mesma forma que o som precisa de meios materiais para se propagar, as ondas luminosas só conseguiriam se propagar no vácuo se este fosse preenchido por um fluido, que recebeu o nome de éter luminífero.

A ideia de o éter luminífero ser um fluido que preenchia o vácuo mantevese até 1817, quando Young e Fresnel descreveram a luz como uma onda transversal. Como ondas transversais não se propagam em fluidos, para eles, o éter seria um sólido elástico que devia ter baixa viscosidade para não retardar o movimento dos corpos e ao mesmo tempo deveria ser rígido para propagar as oscilações das ondas luminosas. Apesar das características intrigantes, a ideia do éter manteve sua existência por longos anos, e em 1860, ganhou credibilidade após Maxwell demonstrar que a luz era uma onda eletromagnética que se propagava nesse meio elástico.

Devido à importância do éter, muitos físicos se dedicaram a desenvolver experiências para comprovar sua existência, dentre elas, a mais precisa foi realizada por Albert Michelson e Edward Morley em 1887. A experiência deveria constatar o movimento da Terra através do éter medindo a velocidade da luz em diferentes direções. A ideia básica era mostrar que dois feixes luminosos 
perpendiculares deveriam percorrer distâncias iguais em tempos diferentes por causa da diferença de suas velocidades em relação à Terra. Para isso, construíram um aparelho, o interferômetro, no qual um feixe de luz é dividido em dois ao passar por um espelho parcialmente refletor. Os feixes divididos seguem em direções diferentes. Um feixe segue paralelo à direção do movimento da Terra em relação ao Sol, e o outro perpendicular a esta direção. Ao serem refletidos em espelhos, os feixes se cruzam e se superpõem e após atravessarem uma lente projetam-se dando origem a franjas de interferência construtiva ou destrutiva. A Figura 3 traz um esquema do interferômetro de Michelson e Morley.

Figura 3 - Esquema do interferômetro de Michelson e Morley.

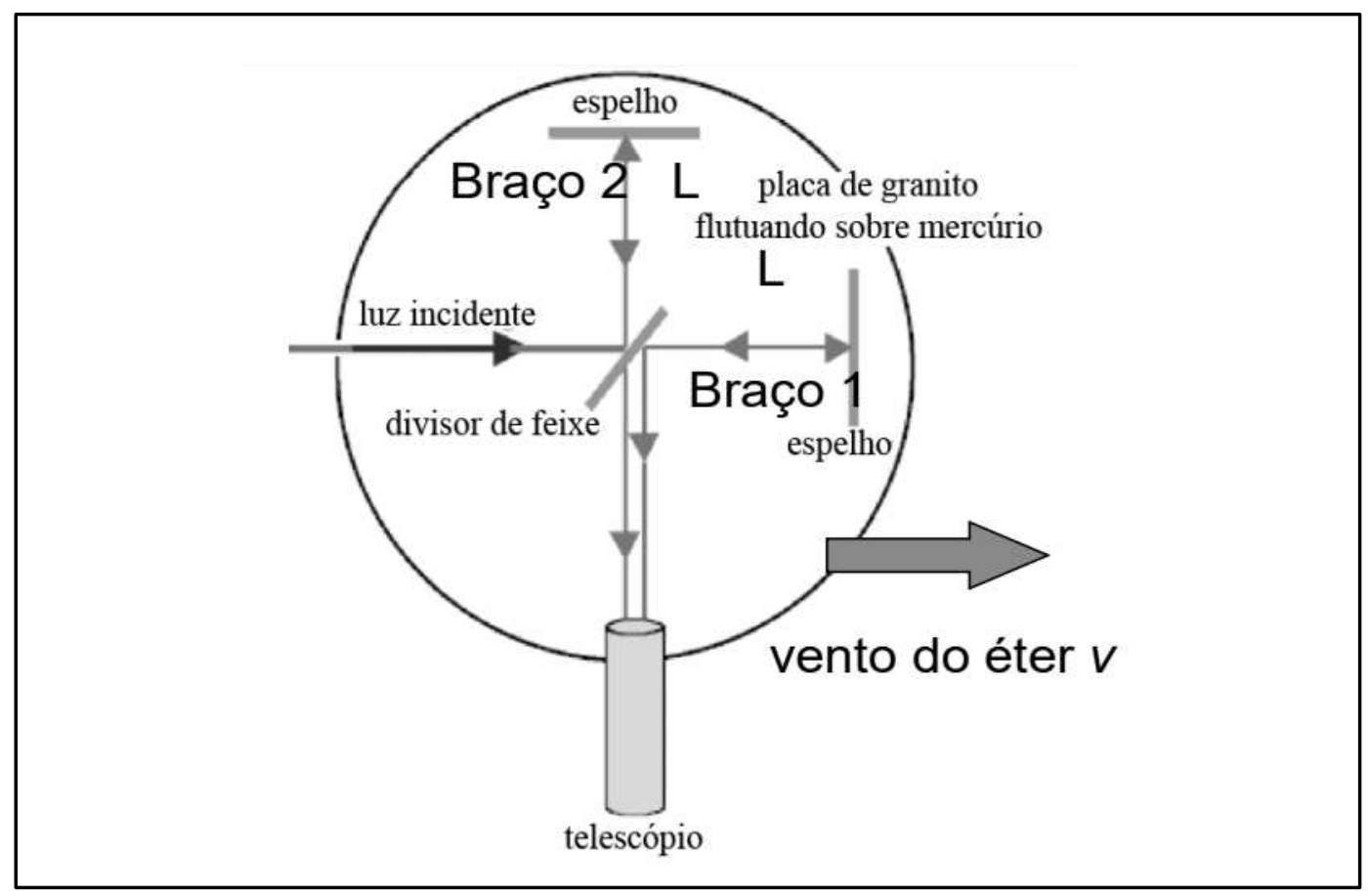

Fonte:https://sites.ifi.unicamp.br/graduacao/files/2013/12/F589_20162S_16.09.3 0_Aula04.pdf

Se os feixes percorressem a mesma distância com a mesma velocidade eles se juntariam com a mesma fase. Se, a velocidade de um dos feixes fosse diferente do outro, os dois feixes de juntariam com uma diferença de fase. Após realizarem o experimento repetidas vezes, o resultado esperado não foi alcançado, pois, as velocidades dos feixes não apresentavam variação. Ou seja, não foi possível determinar a velocidade da Terra em relação ao éter, portanto, não se encontrou nenhuma evidência da existência do éter. 
Diante dos resultados negativos várias interpretações surgiram e o conceito do éter ainda se manteve estável. Por volta de 1890, Hendrik Antoon Lorentz (1853 - 1928), grande defensor do éter, ao apresentar sua teoria eletromagnética, buscou justificar o resultado negativo da experiência de Michelson e Morley acrescentando à sua teoria a chamada hipótese da contração. De acordo com Lorentz, todo corpo em movimento no éter sofre um encurtamento na direção de seu movimento, e por consequência o tempo decorrido nesse movimento sofria uma dilatação, que recebeu o nome de tempo local. Para a descrição de sua hipótese, Lorentz desenvolveu um conjunto de equações que ficaram conhecidas como as Transformações de Lorentz que veremos mais adiante no texto.

O físico francês Jules Henri Poincaré (1854 - 1912) também grande defensor do éter, disse que, caso fosse possível a detecção do éter,

(...) seríamos levados a concluir que esses fenômenos poderiam nos revelar não só os movimentos relativos dos corpos materiais, mas o que pareceria ser seus movimentos absolutos. Seria ainda preciso que houvesse um éter para que os assim chamados movimentos absolutos não fossem seus deslocamentos em relação a um espaço vazio, mas seus deslocamentos em relação a algo de concreto. (POINCARÉ apud PEDUZZl, 2009, p.134)

Desse modo, o problema da detecção do éter estava diretamente relacionado com a possibilidade de se detectar o movimento absoluto. Rodrigues (2001, p.37), diz que "o éter assumia um papel similar ao do espaço absoluto na teoria newtoniana, na medida em que o estado de movimento dos corpos era definido a partir desse referencial singular, privilegiado".

A resposta para o problema da detecção do éter só veio a ser apresentada em 1905, quando Albert Einstein (1879 - 1955) publicou sua Teoria da Relatividade.

\subsection{O SURGIMENTO DA TEORIA DA RELATIVIDADE}

$\mathrm{Na}$ maior parte das vezes em que se fala sobre Relatividade, o primeiro nome que se pensa é o de Albert Einstein, mas, antes dele, o Princípio da Relatividade já fazia parte do estudo da Mecânica e a origem dessa teoria aconteceu muito tempo antes, com Galileu Galilei (1564 - 1642). É importante 
salientar que, outros físicos também contribuíram para a elaboração da Teoria da Relatividade, como Lorentz e Poincaré.

\subsubsection{A relatividade de Galileu}

O trabalho sobre relatividade desenvolvido por Galileu é fundamental para a compreensão da Teoria da Relatividade Restrita proposta por Einstein.

Galileu foi um dos primeiros a relativizar os movimentos em seus estudos, ou seja, para afirmar que um corpo está em movimento ou em repouso é necessário estabelecer um sistema de referência. Entende- se por sistema de referência um local onde o movimento é observado e medido (HEWITT, 2015, p.559).

O chamado Princípio da Relatividade de Galileu estabelece que o movimento de qualquer corpo está sujeito às mesmas leis, tanto num sistema de referência que está em repouso quanto num sistema de referência que se desloca com velocidade constante e em linha reta: tais sistemas são chamados de referenciais inerciais.

\subsubsection{Transformações de Galileu}

Galileu desenvolveu equações matemáticas que relacionam a descrição de um mesmo evento para sistemas de referenciais distintos: são as transformações da relatividade de Galileu.

Considere um evento ocorrendo em um sistema de referência, chamado $S$, que é composto pelas coordenadas espaciais $x, y, z$. Considere também outro sistema, denominado S', composto pelas coordenadas espaciais $x^{\prime}, y^{\prime}, z^{\prime}$. O referencial S' se move com velocidade constante $v$ em relação ao sistema $S$. O deslocamento de S' acontece na mesma direção do eixo x de $S$, conforme mostra a Figura 4: 
Figura 4 - Movimento relativo entre os sistemas S e S'
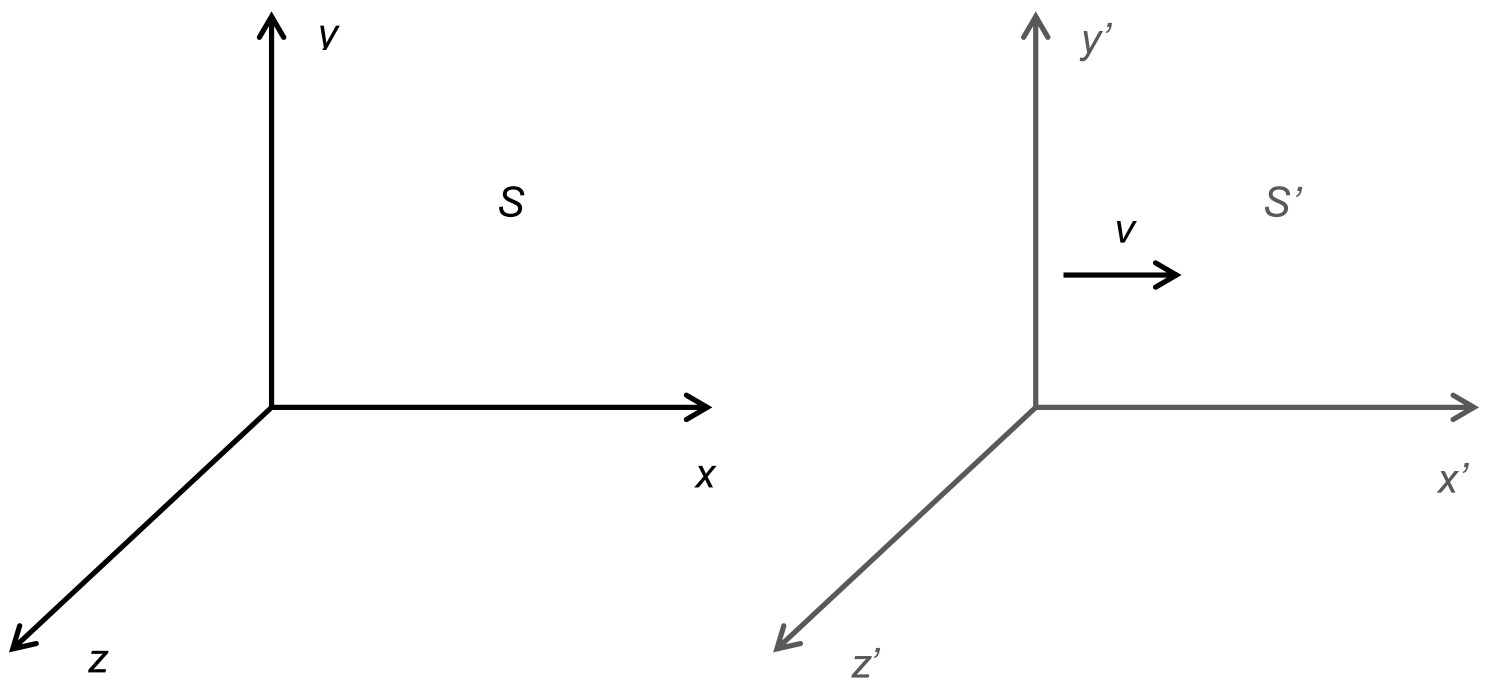

Fonte: Elaborado pela autora

Consideremos agora que no instante $t=t^{\prime}=0$, as origens dos dois referenciais coincidam, portanto, $x_{0}=x_{0}^{\prime}, y_{0}=y_{0}{ }^{\prime} \mathrm{e} z_{0}=z_{0}$. Há então a ocorrência de um evento num ponto $P$, suas coordenadas em $S$ são definidas por $(x, y, z, t) \mathrm{e}$ em $S^{\prime}$ por $\left(x^{\prime}, y^{\prime}, z^{\prime}, t^{\prime}\right)$, então, podemos dizer que as coordenadas do ponto $\mathrm{P}$ coincidem em $S$ e $S^{\prime}$. Observe a Figura 5.

Figura 5 - Referenciais $S$ e $S^{\prime}$ no instante $t=t^{\prime}=0$, em que as origens se coincidem.

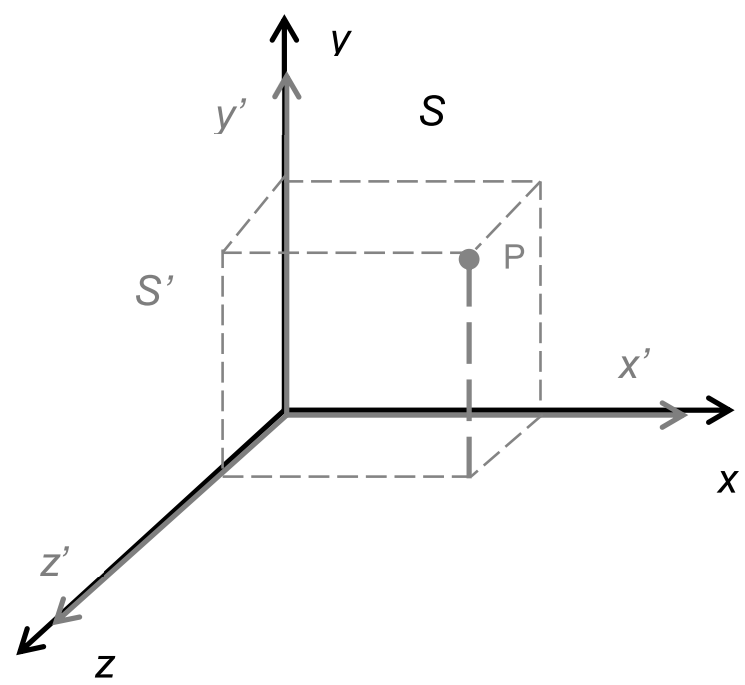

Fonte: Elaborado pela autora 
Tomando agora um instante posterior onde $\mathrm{t}=\mathrm{t}^{\prime}>0$, e como o referencial $S$ ' se move com velocidade constante $v$ em relação ao referencial $S$, temos que, as coordenadas do ponto $\mathrm{P}$ em $\mathrm{S}$ e $\mathrm{S}^{\prime}$ não são mais as mesmas, pois, agora as origens não coincidem. A relação entre as coordenadas é mostrada na Figura 6 :

Figura 6 - Relação de coordenadas entre o referencial S e S'

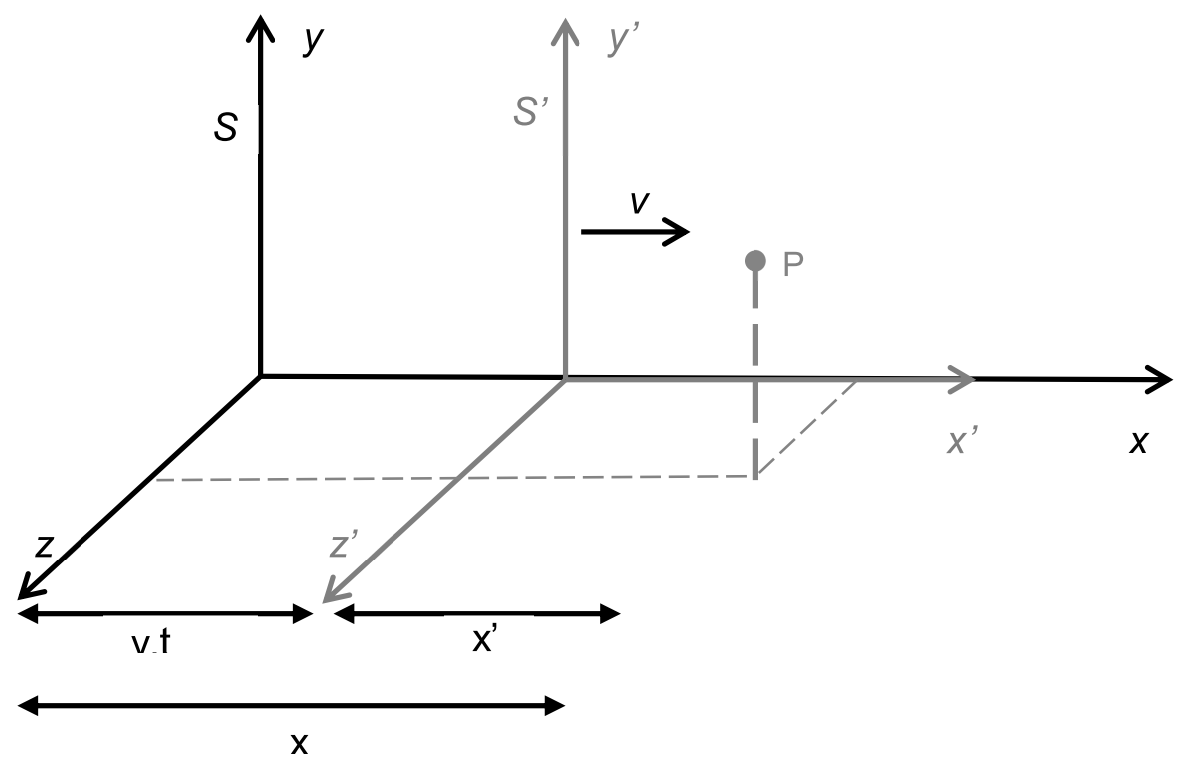

Fonte: Elaborado pela autora

Portanto, a relação entre as coordenadas do referencial $S$ com o S', pode ser escrita como:

$$
\begin{aligned}
x^{\prime} & =x-\mathrm{vt} \\
y^{\prime} & =y \\
z^{\prime} & =z \\
t^{\prime} & =t
\end{aligned}
$$

As equações (1), (2), (3) e (4) são conhecidas como transformações de Galileu. Podemos observar que os intervalos de tempo medidos nos diferentes referenciais $\left(t^{\prime}=t\right)$ são iguais: portanto, Galileu considerava o tempo uma grandeza absoluta, independente do referencial adotado.

Utilizando as equações (1), (2), (3) e (4) é possível obter a transformação inversa, substituindo $v$ por $-\mathrm{v}$, pois, para um observador em $S$ ' o referencial $S$ se move no sentido oposto ao da orientação positiva. 


$$
\begin{aligned}
& x=x^{\prime}+v t \\
& y=y^{\prime} \\
& z=z^{\prime} \\
& t=t^{\prime}
\end{aligned}
$$

\subsubsection{Adição galileana de velocidades}

As transformações de coordenadas de Galileu também permitem relacionar as velocidades referentes ao deslocamento de um mesmo corpo em referenciais distintos.

Considerando que a posição do ponto $\mathrm{P}$ varia com o tempo (Figura 6) ao longo de $x$ e de $x$, temos que, o ponto $P$ possui uma velocidade $u$ em relação ao referencial $S$, e em relação ao referencial $S$ ', a velocidade de $\mathrm{P}$ é u'. Assumindo que $S$ ' se move com uma velocidade $v$ em relação a $S$, e ainda considerando a invariância do tempo para referenciais distintos, usando as equações (1), (2) e (3), temos que,

$$
\begin{aligned}
& u_{x}^{\prime}=u_{x}-v \\
& u_{y}^{\prime}=u_{y} \\
& u_{z}^{\prime}=u_{z}
\end{aligned}
$$

Portanto, a velocidade em diferentes referenciais muda somente na direção em que apresentam movimento relativo.

Dessa forma, de acordo com a relatividade de Galileu, as posições e as velocidades são diferentes para sistemas de referências distintos.

Isaac Newton (1642 - 1727) inseriu em seus estudos e obras as ideias desenvolvidas por Galileu, de maneira que, a composição de velocidades na mecânica newtoniana é alicerçada na adição galileana de velocidades.

\subsubsection{A mecânica de Newton}

A Física Clássica, em especial a Mecânica Clássica, dominante no final do século $X I X$, teve como um dos principais personagens Isaac Newton, que usou a matemática de forma revolucionária e reuniu conhecimentos deixados por outros grandes cientistas para as explicações dos fenômenos físicos. 
A teoria newtoniana tem como base três princípios: o da Inércia, o Fundamental da Mecânica e o da Ação e Reação. Tais princípios são conhecidos como Leis de Newton.

O conceito de inércia foi estabelecido primeiramente por Galileu, que após experimentos com planos inclinados concluiu que na ausência de uma força, um objeto móvel deverá continuar se movendo. Essa propriedade de um objeto tender a resistir a mudanças no seu movimento recebeu o nome de inércia por Galileu (HEWITT, 2015).

Newton aperfeiçoou o conceito de inércia de Galileu, e em sua obra o Principia, enunciou a sua primeira lei, o seu Princípio da Inércia:

Todo objeto permanece em seu estado de repouso ou de rapidez uniforme em uma linha reta a menos que uma força resultante não nula seja exercida sobre ele. (NEWTON, apud HEWITT, 2015, p.26)

Este princípio traz como implicação a questão do movimento ser relativo, ou seja, só é possível dizer que um corpo está em repouso ou em movimento estabelecendo um referencial. De acordo com Newton, era necessário adotar um referencial absoluto, de modo que, a partir dele, fosse possível determinar o movimento dos outros corpos. Newton definiu esse referencial como o espaço absoluto:

O espaço absoluto, por sua natureza e sem qualquer relação com algo externo, permanece sempre semelhante e imóvel; o relativo é certa medida ou dimensão móvel desse espaço, a qual nossos sentidos definem por sua situação relativamente à terra. (NEWTON, apud RODRIGUES, 2001, p.30)

Apesar das críticas de que foi alvo, a concepção newtoniana de espaço absoluto foi gradativamente se consolidando e, de acordo com Porto (2008),
A física newtoniana não só é coerente, mas é estruturalmente dependente da ideia de um espaço absoluto, na medida em que distingue dois tipos de observadores: aqueles para os quais são válidas as três leis fundamentais da mecânica, chamados de inerciais, e os não inerciais, para quem os fenômenos mecânicos não obedecem às Leis de Newton. (...) A existência completamente objetiva deste espaço absoluto se torna, portanto, um elemento fundamental à consistência lógica da teoria newtoniana do movimento. (PORTO, 2008, p.1603-2, 3)

Desse modo, a física newtoniana reafirmou o princípio da relatividade de Galileu, usando o conceito de referenciais inerciais. No final do século XIX, os 
físicos não questionavam esse princípio, mas perceberam que ele não se aplicava às leis do Eletromagnetismo.

\subsubsection{O Eletromagnetismo}

O estudo dos fenômenos envolvendo Eletricidade e Magnetismo originouse com os gregos, que observaram a propriedade de atração ou repulsão que determinados materiais apresentavam quando interagiam. Entretanto, os gregos não conseguiam diferenciar os fenômenos elétricos dos magnéticos. Somente no século XVI é que as propriedades elétricas foram diferenciadas das magnéticas. Durante muitos anos a Eletricidade e o Magnetismo foram desenvolvidos desvinculados um do outro, até que, no século XIX, começaram a surgir algumas evidências da relação entre esses dois ramos da física.

Em 1819, o físico dinamarquês Hans Christian Oersted (1977-1851) ao apresentar uma conferência, realizou uma experiência que é considerada o início do Eletromagnetismo.

A experiência realizada por Oersted consistia em colocar uma bússola com seu ponteiro perpendicular a um fio por onde passava uma corrente elétrica. Com esta configuração nada poderia ser observado de anormal. Ao colocar o ponteiro paralelamente ao fio, Oersted percebeu que, com a passagem de uma corrente, o ponteiro era desviado em noventa graus. Se o sentido da corrente fosse invertido, o ponteiro girava em sentido oposto. (WOLFF e MORS, 2005, p.19)

Após as observações e conclusões de Oersted, outros cientistas começaram a analisar a relação entre os fenômenos elétricos e magnéticos e muitas descobertas foram realizadas. Podemos citar os trabalhos realizados por André-Marie Ampère (1775-1836), que constatou experimentalmente que dois fios paralelos percorridos por correntes de sentidos opostos se repeliam e quando percorridos por correntes no mesmo sentido se atraiam. Ampère também constatou que uma bobina circular, comportava-se como ímã quando esta transportava corrente. Os estudos dos físicos franceses Jean-Baptiste Biot (17741862) e Félix Savart (1791-1841) culminaram em estabelecer uma lei que permite determinar a intensidade do campo magnético gerado ao redor de um fio condutor percorrido por uma corrente, o que conhecemos hoje por Lei de Biot-Savart. 
Outra importante descoberta foi feita por Michael Faraday (1791-1867), que após realizar muitos experimentos, concluiu que, assim como a corrente elétrica produz campo magnético, um campo magnético variável também produz corrente elétrica em um condutor, que é a indução eletromagnética. $E$ com base em experimentos relacionados à indução magnética, o físico russo Heinrich F.E. Lenz (1804-1865) mostrou que a corrente induzida gera um campo magnético de sentido contrário à variação do que a gerou.

As descobertas acima citadas validaram a relação existente entre os fenômenos elétricos e magnéticos e correspondem à estrutura básica do Eletromagnetismo.

O físico e matemático James Clerk Maxwell (1831-1879) fez uma enorme contribuição para o Eletromagnetismo. Maxwell conseguiu descrever uma formulação matemática que unificou as leis do eletromagnetismo em quatro equações, que são conhecidas como as Equações de Maxwell.

Temos abaixo as quatro equações de Maxwell para os campos elétrico $\vec{E}$ e magnético $\vec{B}$ apresentadas em sua forma diferencial:

$$
\begin{aligned}
\vec{\nabla} \cdot \vec{E} & =\frac{\rho}{\varepsilon_{0}} \\
\vec{\nabla} \cdot \vec{B} & =0 \\
\vec{\nabla} \times \vec{E} & =-\frac{\partial \vec{B}}{\partial t} \\
\vec{\nabla} \times \vec{B} & =\mu_{0} \varepsilon_{0} \frac{\partial \vec{E}}{\partial t}+\mu_{0} \vec{J}
\end{aligned}
$$

onde $\rho$ é a densidade volumétrica de cargas elétricas contidas em um dado volume, $\mu_{0}$ é a permeabilidade magnética no vácuo, e $\varepsilon_{0}$ é a permissividade elétrica no vácuo. Os valores de $\mu_{0}$ e $\varepsilon_{0}$ são encontrados através de medidas que analisam a força coulombiana entre cargas e a força magnética entre correntes, obtendo os seguintes resultados:

$$
\mu_{0}=4 \pi \times 10^{-7} \frac{H}{m}
$$




$$
\varepsilon_{0}=8,85 \times 10^{-12} \frac{F}{m}
$$

A equação (12) é conhecida como Lei de Gauss e relaciona o fluxo de campo elétrico através de uma superfície fechada (superfície gaussiana) que envolve uma densidade de carga $(\rho)$. A equação (13) é a Lei de Gauss para o magnetismo, que determina que o fluxo magnético através de qualquer superfície gaussiana é zero, descrevendo a não existência de monopolos magnéticos. A equação (14) é a Lei de Faraday e descreve que um campo magnético que varia com o tempo gera um campo elétrico. Por fim, a equação (15) é conhecida como Lei de Ampère-Maxwell e mostra que campos magnéticos podem ser gerados através de correntes elétricas ou por campos elétricos que variam no tempo.

Todas as componentes dos campos eletromagnéticos das equações de Maxwell em uma região sem cargas ou correntes elétricas, ou seja, no vácuo, satisfazem a equação de ondas:

$$
\nabla^{2} \Psi-\frac{1}{v^{2}} \frac{\partial^{2} \Psi}{\partial t^{2}}=0
$$

onde $v$ é a velocidade de propagação da onda eletromagnética dada por:

$$
v=\frac{1}{\sqrt{\varepsilon_{0} \mu_{0}}}
$$

Como são conhecidos os valores de $\mu_{0}$ e $\varepsilon_{0}$, temos que, a velocidade de propagação da onda eletromagnética de acordo com as equações de Maxwell é $v \cong 2,99792 \times 10^{8} \mathrm{~m} / \mathrm{s}$.

Desse modo, o resultado encontrado por Maxwell para a velocidade de propagação das ondas eletromagnéticas era muito próximo do valor da velocidade de propagação da luz no ar obtido experimentalmente por Hippolyte Fizeu (1819 _ 1896), o que levou Maxwell a supor que a natureza da luz é de origem eletromagnética.

De acordo com Maxwell,

"A velocidade das ondulações transversais no nosso meio hipotético, calculada a partir das experiências de Eletromagnetismo efetuadas pelo Srs. Kolhraush, tem um valor tão próximo do valor da velocidade calculado a partir de experiências de Óptica realizadas pelo Sr. Fizeau que é difícil de evitar a inferência de que a luz consistirá em ondulações transversais do 
mesmo meio que é a causa dos fenômenos elétricos e magnéticos." (WOLFF e MORS, 2005, p.20)

A hipótese feita por Maxwell de a luz ser de origem eletromagnética foi confirmada em 1887, quando Heinrich Hertz (1857 - 1894) produziu ondas por meio de um circuito oscilante que apresentavam propriedades iguais às da luz, ou seja, podiam ser refratadas, refletidas, difratadas e polarizadas. Com isso, as Equações de Maxwell conseguiram unificar em uma única teoria a Eletricidade, o Magnetismo e a Óptica.

Entretanto, apesar de todo o desenvolvimento proporcionado ao Eletromagnetismo pelas Equações de Maxwell algumas incompatibilidades ainda ocorriam. Uma delas decorre do fato da luz ser uma onda eletromagnética que poderia se propagar no vácuo. O questionamento se dava porque, de acordo com o entendimento da época, toda onda precisava de um meio material para se propagar, portanto, a luz também precisava de um meio para sua propagação. Outra inconsistência se dava pelo valor encontrado para a velocidade da luz (c), deduzido ser constante e aproximadamente igual a $3 \times 10^{8} \mathrm{~m} / \mathrm{s}$. A pergunta sobre essa questão era: a velocidade da luz é medida em relação a quê? Pois, como a velocidade é uma grandeza relativa, diferentes observadores podem medir diferentes velocidades para um mesmo móvel. A resposta encontrada para solucionar tais problemas foi admitir a existência de um referencial absoluto, o éter luminífero. Era neste meio material que a luz se propagava, e em relação a ele é que se media a velocidade da luz.

Peduzzi (2009) escrevendo sobre o éter afirma:

De qualquer modo, a ideia desse meio contínuo, de propriedades ainda desconhecidas, que representava também a possibilidade da materialização do espaço absoluto da mecânica newtoniana, resultava preferível à concepção de propagação das ondas eletromagnéticas através do vácuo... A comprovação experimental da existência desse fluido, através de seus efeitos sobre o movimento dos corpos, tornou-se, definitivamente, tarefa não apenas necessária como imprescindível. (PEDUZZl, 2009, p.115)

Conforme já mencionado anteriormente no texto, muitas foram as tentativas de se comprovar a existência do éter, mas, nenhuma obteve resultados positivos.

Outro grande problema acontecia quando as Transformações de Galileu eram aplicadas nas Equações de Maxwell. Verificava-se que estas não eram 
invariantes, ou seja, para diferentes referenciais obtinham-se diferentes efeitos eletromagnéticos. Assim, o Princípio da Relatividade de Galileu e o Eletromagnetismo não eram compatíveis e estabeleciam um problema conceitual. Segundo Nussenzveig uma das seguintes opções deveria ser válida,

(i) A mecânica newtoniana e as equações de Maxwell são válidas, mas o princípio de relatividade não se aplica a todas as leis físicas: existe um referencial absoluto (o éter), onde a velocidade da luz é c em todas as direções, e deve ser possível, por meio de experiências eletromagnéticas, detectar um movimento retilíneo e uniforme em relação ao referencial absoluto éter.

(ii) O princípio de relatividade aplica-se a todas as leis físicas e a mecânica newtoniana é correta. Neste caso, as equações de Maxwell teriam de ser modificadas, e deveria ser possível observar desvios das leis da eletrodinâmica clássica.

(iii) O princípio de relatividade aplica-se a todas as leis físicas, e as equações de Maxwell são corretas. Neste caso, a mecânica newtoniana e a transformação de Galileu não podem ser corretas: deve ser possível observar desvios das leis da mecânica newtoniana. (NUSSENZVEIG, 2002, p.177)

Como veremos adiante, é valida a opção (iii), e as inconsistências apresentadas anteriormente foram esclarecidas pela teoria proposta por Albert Einstein.

\subsubsection{A relatividade de Einstein}

A Teoria da Relatividade Restrita proposta por Albert Einstein (1879-1955) surgiu devido à incompatibilidade entre a Mecânica Clássica e o Eletromagnetismo, sendo o principal problema a não validade do princípio da relatividade de Galileu para os fenômenos eletromagnéticos.

Em 1905, Einstein publicou o artigo Sobre a Eletrodinâmica dos Corpos em Movimento, em que descreve as ideias básicas de sua teoria. No artigo Einstein comenta sobre a descrição aparentemente assimétrica dos efeitos de indução eletromagnética entre um ímã e um fio condutor. $O$ trecho a seguir relata sobre $o$ problema:

Que a eletrodinâmica de Maxwell - como a mesma hoje em dia é compreendida - na sua aplicação a corpos em movimento leve a assimetrias que parecem não estar relacionadas aos fenômenos, é conhecido. Se pense, por exemplo, à interação eletrodinâmica entre um ímã e um condutor. O fenômeno observável depende 
aqui somente do movimento relativo entre condutor e ímã, enquanto, no entendimento comum, os dois casos, que um ou o outro destes corpos esteja em movimento, têm que ser rigorosamente separados entre si. De fato, estando o ímã em movimento e o condutor em repouso, produz-se no entorno do ímã um campo elétrico com um certo valor de energia, que, nas regiões onde se encontram partes do condutor, dá origem a uma corrente elétrica. Porém, estando o ímã em repouso e movimentando-se o condutor, não gera-se então nos arredores do ímã nenhum campo elétrico, mas gera-se, por outro lado, no condutor uma força eletromotriz, à qual não corresponde uma energia, mas que - pressuposta a igualdade do movimento relativo para os dois casos considerados - dá origem a correntes elétricas do mesmo tamanho e com a mesma direção, como as produzidas no primeiro caso pelas forças elétricas. (EINSTEIN apud PIATTELLA, 2020, p.158)

Einstein propõe então os dois postulados que constituem a base da Teoria da Relatividade Restrita e que, segundo ele, resolveriam o problema da não validade do princípio da relatividade aos fenômenos eletromagnéticos. $\mathrm{O}$ primeiro postulado seria uma generalização do princípio da relatividade para todos os fenômenos da natureza, e o segundo afirma a invariância da velocidade da luz para qualquer referencial. Einstein também diz sobre a não necessidade da existência do éter como propriedade de repouso absoluto.

Exemplos do mesmo tipo, assim como as tentativas sem sucesso de detectar um movimento da Terra relativo ao "meio de propagação da luz", levam à hipótese que nenhumas características dos fenômenos correspondem ao conceito de repouso absoluto, não somente na mecânica mas também na eletrodinâmica, mas que, ainda mais, para todos os sistemas de coordenadas para os quais as equações da Mecânica valem, também as mesmas leis da eletrodinâmica e da ótica são válidas, como isso já tem sido provado para quantidades de primeira ordem. Queremos elevar esta hipótese (cujo conteúdo será chamado doravante "princípio de relatividade") para postulado e além disto incluir o postulado, aparentemente incompatível com o primeiro, que a luz propaga no espaço vazio sempre com uma determinada velocidade $\mathrm{V}$, independente do estado de movimento do corpo que a emite. Estes dois postulados são suficientes para chegar numa eletrodinâmica dos corpos em movimento simples e livre de contradições com base na teoria Maxwelliana para corpos em repouso. A introdução de um "éter da luz" se revelará desnecessária, pois, segundo a interpretação a ser desenvolvida aqui, não introduz-se um "espaço de repouso absoluto" dotado de propriedades extraordinárias e nem associa-se um vetor velocidade a um ponto do espaço vazio em que processos eletromagnéticos ocorrem. (EINSTEIN apud PIATTELLA, 2020, p.158) 
Desse modo, os dois postulados propostos por Einstein se resumem em:

1. As leis da Física são iguais em qualquer referencial inercial, ou seja, não existe referencial inercial preferencial.

2. A velocidade da luz no vácuo é a mesma para todos os observadores em referenciais inerciais e não depende do estado de movimento da fonte.

A generalidade de tais postulados implicou em algumas mudanças na mecânica clássica, onde, as Transformações de Galileu foram modificadas e a noção de tempo e espaço absoluto teve de ser abandonada para uma redefinição de tais conceitos. De acordo com Peduzzi,

A partir da 'igualdade de direito' de todos os referenciais inerciais, da constância da velocidade da luz e da hipótese de homogeneidade do espaço e do tempo, Einstein deduz as consequências de sua teoria, reformulando as noções fundamentais de espaço e de tempo da mecânica newtoniana; mostrando que o conceito de simultaneidade é relativo; eliminando o conceito de éter; obtendo as equações de transformação de Lorentz e discutindo o seu significado físico (em particular, a influência do movimento sobre a marcha dos relógios e as dimensões dos objetos); provando ser fisicamente impossível velocidades superiores à da luz; demonstrando o aumento da massa com a velocidade e a equivalência massa-energia, entre outras coisas. (PEDUZZl, 2009, p.153)

\subsubsection{Relatividade da Simultaneidade}

O conceito de simultaneidade está relacionado ao fato de dois eventos ocorrerem no mesmo instante de tempo. Uma das consequências do segundo postulado de Einstein é que eventos simultâneos em um determinado referencial, não serão necessariamente simultâneos em outro referencial.

Por exemplo, considere que no instante $t=t^{\prime}=0$ dois sistemas de referência $S$ e S' possuem eixos e origens coincidentes, e que $S$ ' se movimente na direção de $x$ com velocidade $v$ em relação a $S$. Considere também que no instante $t=0$ sejam coincidentes os pares de pontos $\left(A, A^{\prime}\right),\left(B, B^{\prime}\right)$ e $\left(O, O^{\prime}\right)$ dos dois sistemas, sendo o pontos $O$ e $O^{\prime}$ os pontos médios dos segmentos $A B$ e $A^{\prime} B^{\prime}$ respectivamente, e onde se encontram os observadores dos referenciais $S$ e $S^{\prime}$, conforme mostra a figura 7 . 
Figura 7 - Referenciais S e S' movendo-se com velocidade relativa $v$

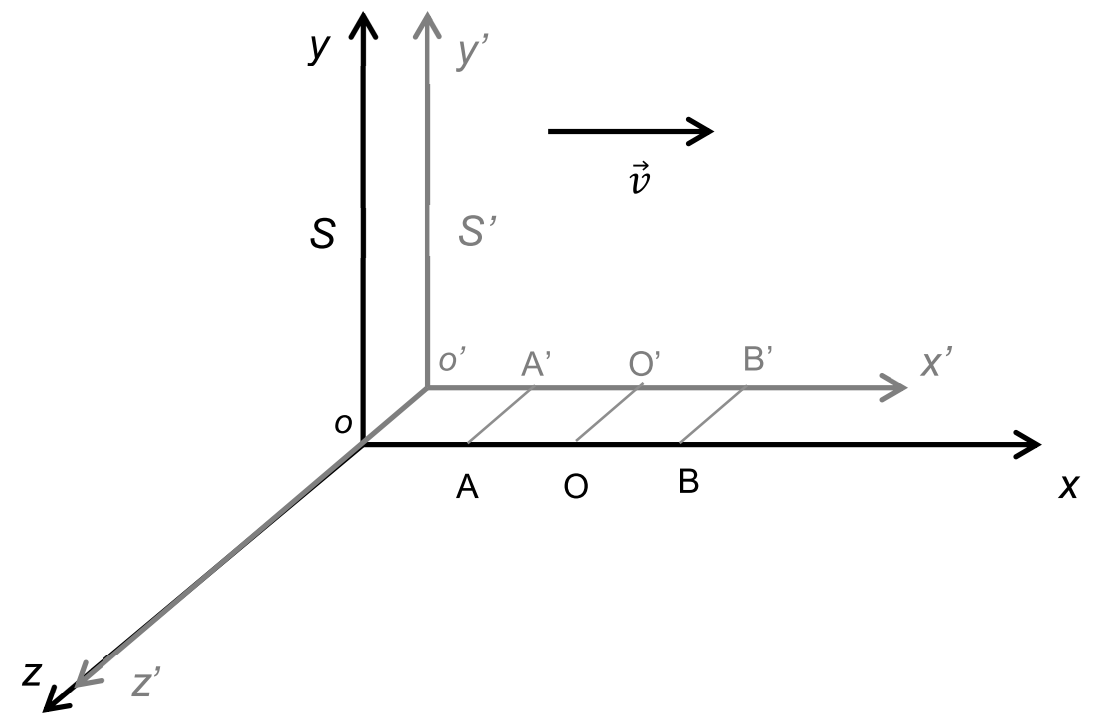

Fonte: Elaborado pela autora

A partir dos pontos A' e B' do referencial S', são emitidos dois pulsos de luz. O observador O' que está equidistante de A' e de B' observa que os pulsos o atingem simultaneamente. Agora, para o observador $O$, os dois eventos (pulsos partindo de A' e B') não são simultâneos. Isso ocorre porque, na medida em que $S^{\prime}$ se desloca, A' se aproxima de $O$, enquanto $B$ ' se afasta dele. Com isso, a frente de onda originada em $A^{\prime}$ percorre até $O$ uma distância menor do que aquela que tem que percorrer a frente de onda que parte de B'; como ambas se movem com a mesma velocidade $c$, ocorre uma diferença nos tempos de chegada dos dois pulsos até $\mathrm{O}$. Da mesma forma, conclui-se que, se os eventos tivessem origem nos pontos $A$ e $B$ do referencial $S$, eles seriam simultâneos para $\mathrm{O}$, e não para $\mathrm{O}$,' que perceberia primeiro o sinal proveniente de $B$.

$O$ fato de dois eventos serem simultâneos para um observador em um dado referencial e não apresentarem simultaneidade em outro sistema de referência demonstra que, o conceito de simultaneidade é relativo, e não absoluto, como descrevia a mecânica clássica.

\subsubsection{As transformações da Relatividade de Einstein}

Devido ao segundo postulado da Teoria da Relatividade de Einstein, o princípio da constância da velocidade da luz para qualquer referencial inercial, 
surgiu a necessidade de que as transformações propostas por Galileu sofressem modificações. Assim, partindo de seus dois postulados, Einstein deduz outras equações para efetuar as transformações de coordenadas espaciais e temporais entre dois sistemas inerciais, sendo um referencial S' movendo-se na direção $x$, relativamente a um referencial $S$, com velocidade v. São elas:

$$
\begin{array}{cccc}
x^{\prime}=\gamma(x-v t) & \text { ou } & x=\gamma\left(x^{\prime}+v t^{\prime}\right) & \text { transformação inversa } \\
t^{\prime}=\gamma\left(t-\frac{v}{c^{2}} x\right) & \text { ou } & t=\gamma\left(t^{\prime}+\frac{v}{c^{2}} x^{\prime}\right) & \text { transformação inversa } \\
y^{\prime}=y & \\
z^{\prime}=z &
\end{array}
$$

onde $c$ é a velocidade da luz no vácuo e

$$
\gamma=\frac{1}{\sqrt{1-\frac{v^{2}}{c^{2}}}}
$$

As equações acima obtidas por Einstein já haviam sido propostas por Lorentz, com o objetivo de tornar as equações de Maxwell invariantes. Lorentz não as deduziu a partir de uma interpretação de fenômenos físicos, ele considerava essas equações apenas um artifício matemático útil para adequar a mecânica clássica da época aos resultados negativos da experiência de Michelson-Morley. Por isso, as equações (18), (19), (20) e (21) ficaram conhecidas como as Transformações de Lorentz, e $\gamma$ é chamado de fator de Lorentz.

As transformações nas direções y e $\mathrm{z}$ são as mesmas, pois o movimento acontece apenas na direção x. A diferença apresentada nas Transformações de Lorentz, é que além do fator de Lorentz $(\gamma)$, o tempo depende da posição e da velocidade. Assim, a noção de tempo absoluto da mecânica newtoniana é alterada pela concepção relativística. Nessa nova visão, o tempo passa a ser considerado como uma dimensão a mais e simetricamente dependente das dimensões espaciais.

Temos ainda que, para velocidades muito baixas, $v \ll c$ as Transformações de Lorentz são semelhantes às de Galileu, tornando a relatividade Galileana um caso particular da relatividade especial. 


\subsubsection{Dilatação Temporal}

Uma consequência da constância da velocidade da luz é que as medidas de tempo não são medidas absolutas, como afirmava Galileu e Newton, pois tais medidas dependem do referencial inercial em que o tempo será medido.

Considere que o referencial $S^{\prime}$ se move na direção do eixo $x$, com velocidade $v$ em relação a outro sistema $\mathrm{S}$, que encontra-se em repouso. Suponha dois eventos que aconteçam, um no ponto $A^{\prime}$ num tempo $t_{1}$ ', e outro no mesmo ponto $A^{\prime}$ no tempo $t_{2}^{\prime}$.

Usando a equação (19) da Transformação de Lorentz temos:

$$
t_{1}=\frac{t_{1}^{\prime}-v A^{\prime} / c^{2}}{\sqrt{1-\frac{v^{2}}{c^{2}}}} \quad \text { e } \quad t_{2}=\frac{t_{2}^{\prime}-v A^{\prime} / c^{2}}{\sqrt{1-\frac{v^{2}}{c^{2}}}}
$$

Assim,

$$
\begin{gathered}
t_{2}-t_{1}=\frac{t_{2}{ }^{\prime}-t_{1}{ }^{\prime}}{\sqrt{1-\frac{v^{2}}{c^{2}}}} \\
\Delta t=\frac{\Delta t_{p}}{\sqrt{1-\frac{v^{2}}{c^{2}}}} \\
\Delta t=\gamma \Delta t_{p}
\end{gathered}
$$

onde $\Delta t_{p}=t_{2}{ }^{\prime}-t_{1}{ }^{\prime}$ é chamado de tempo próprio e representa o intervalo de tempo entre dois eventos que acontecem no mesmo lugar.

$\mathrm{O}$ intervalo de tempo $\Delta t=t_{2}-t_{1}$ medido em qualquer outro referencial será sempre maior que o tempo próprio $\Delta t_{p}$.

As equações (23) e (24) expressam o fenômeno relativístico denominado dilatação temporal. Para velocidades praticadas em nosso cotidiano $(v \ll c)$, o fator $\gamma$ tende a um, e o tempo medido pelos dois observadores é praticamente o mesmo, estando de acordo com os resultados da mecânica newtoniana. Entretanto, quando $v$ é próxima de $c$, o fator $\gamma$ torna-se significativo e a diferença dos tempos medidos pelos observadores também. Como $\gamma>1$, para 0 
observador em repouso em relação à fonte de luz, os eventos ocorrem como se o tempo passasse mais lentamente em comparação ao observador em movimento em relação à fonte.

\subsubsection{Contração do Espaço}

De maneira análoga à dilatação do tempo, temos como consequência dos Postulados da Relatividade Restrita a relatividade do comprimento. A distância entre dois pontos terá valores diferentes para observadores que se encontram em movimento relativo um em relação ao outro.

Considere um observador em repouso em relação a um sistema referencial $\mathrm{S}$, segurando uma barra de comprimento $L_{p}$, onde $L_{p}=x_{2}-x_{1}$ é chamado de comprimento próprio (comprimento de um objeto medido no referencial no qual o objeto está em repouso). Esta barra se encontra em repouso ao longo do eixo $\mathrm{x}, \mathrm{e}$ suas extremidades se encontram nas posições $x_{2} e x_{1}$. Para um observador que se encontra no referencial $\mathrm{S}^{\prime}$, a barra se move com velocidade $v$, que é a velocidade do referencial $S$ ' e comprimento da barra é dado por $L=x_{2}{ }^{\prime}-x_{1}{ }^{\prime}$, onde $x_{2}{ }^{\prime}$ é a posição de uma extremidade num tempo $t_{2}^{\prime}$ e $x_{1}{ }^{\prime}$ é a posição da outra extremidade no mesmo tempo $t_{1}^{\prime}=t_{2}^{\prime}$.

Usando a equação (18) inversa da Transformação de Lorentz , temos:

$$
\begin{array}{lll}
x_{2}=\gamma\left(x_{2}^{\prime}+v t_{2}^{\prime}\right) & \mathrm{e} & x_{1}=\gamma\left(x_{1}{ }^{\prime}+v t_{1}^{\prime}\right) \\
x_{2}=\frac{\left(x_{2}^{\prime}+v t t_{2}\right)}{\sqrt{1-\frac{v^{2}}{c^{2}}}} & \mathrm{e} & x_{1}=\frac{\left(x_{1}{ }^{\prime}+v t_{1}\right)}{\sqrt{1-\frac{v^{2}}{c^{2}}}}
\end{array}
$$

Como $t_{1}^{\prime}=t_{2}^{\prime}$, temos

$$
\begin{gathered}
x_{2}-x_{1}=\frac{x_{2}^{\prime}-x_{1}^{\prime}}{\sqrt{1-\frac{v^{2}}{c^{2}}}} \\
L_{p}=\frac{L}{\sqrt{1-\frac{v^{2}}{c^{2}}}} \\
L=\frac{L_{p}}{\gamma}
\end{gathered}
$$


A equação (26) expressa o fenômeno relativístico denominado contração do comprimento e é conhecida como Contração de Lorentz-FitzGerald, pelo fato de ter sido inicialmente sugerida por FitzGerald e Lorentz. Para esses cientistas e Einstein, essa equação apresenta significados físicos diferentes:

De acordo com Lorentz e FitzGerald, a contração de um corpo na direção do movimento é um fenômeno físico real, que ocorre com todos os corpos que se movem através do éter. Por isso, a velocidade que aparece na transformação de Lorentz refere-se ao movimento do objeto material em relação ao éter, estacionário. $\mathrm{Na}$ relatividade especial, a contração é apenas um efeito aparente, devido ao movimento relativo entre o objeto e o observador. Não há uma diminuição real das dimensões do objeto. Segundo Einstein, é exatamente esse aspecto da relatividade do movimento de dois observadores que faz com que cada um atribua ao outro um efeito de contração na direção do movimento. (PEDUZZI, 2009, p.167)

Para velocidades praticadas em nosso cotidiano $(v \ll c)$, o fator $\gamma$ tende a um, e o tempo medido pelos dois observadores é praticamente o mesmo, estando de acordo com os resultados da mecânica newtoniana. Entretanto, quando $v$ é próxima de $c$, o fator $\gamma$ torna-se significativo. Como $\gamma>1$, o comprimento da barra medido por um observador em movimento em relação a ela $(L)$ é menor do que o comprimento medido por um observador no referencial em repouso em relação a ela $\left(L_{P}\right)$.

\subsubsection{Equivalência Massa-Energia}

O ano de 1905 é conhecido como o Annus Mirabilis (ano miraculoso), pois foi nesse ano que Einstein escreveu quatro artigos que contribuíram para a revolução científica provocada na Física Clássica. No quarto artigo publicado, intitulado "A Inércia de um Corpo Depende do seu Conteúdo Energético?", Einstein demonstra outras consequências dos postulados propostos no terceiro artigo, "Sobre a Eletrodinâmica dos Corpos em Movimento". Juntos, esses dois artigos passaram a ser chamados de Teoria da Relatividade Restrita. O termo Restrita se dá pelo fato da teoria abordar apenas sistemas inerciais, ou seja, sistemas que não estão acelerados.

Nesse quarto artigo, Einstein, a partir de um "Gedanken Experiments" (experimento de pensamento), e de maneira simples e direta, investiga as 
relações entre massa e energia e, a partir da lei da conservação da energia, deduz a famosa equação $E_{0}=m c^{2}$.

Vamos agora desenvolver, de maneira simplificada, a dedução da equação, a partir do experimento de pensamento proposto por Einstein.

Considere dois sistemas de coordenadas inerciais, sendo o sistema $S(x, y, z)$ e o sistema $S^{\prime}\left(x^{\prime}, y^{\prime}, z^{\prime}\right)$, onde o referencial $S^{\prime}$ se move com velocidade $v$ na direção do eixo $x^{\prime}$, conforme mostra a figura . Considere que no referencial $S$ encontra-se um corpo que emite simultaneamente dois pulsos luminosos de mesma intensidade, mas em sentidos opostos. Os pulsos transportam a mesma energia $\left(\frac{E}{2}\right)$ e também momentum linear.

Figura 8: Esquema de pulsos sendo emitidos no referencial $S$

$$
E_{1}=E_{0}-E
$$

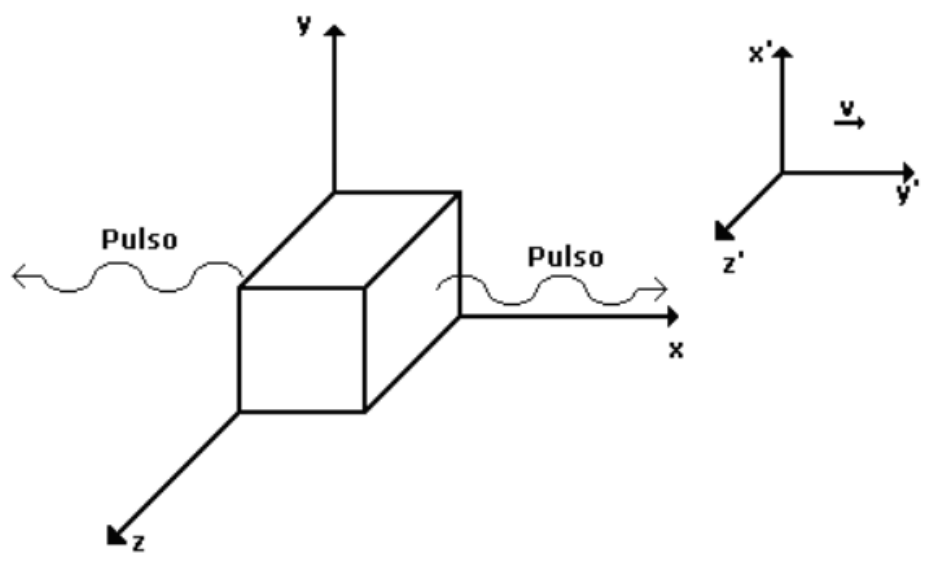

Fonte: OSTERMANN, F.; RICCI T. F. 2004

O corpo que emite os pulsos encontra-se em repouso no referencial $S$ e permanece em repouso mesmo após a emissão dos pulsos. Portanto, a energia cinética do corpo é sempre nula em $\mathrm{S}$.

Entretanto, pelo princípio de conservação de energia, ao emitir os pulsos de luz ocorre uma queda no valor da energia inicial do corpo, $E_{0}$. Essa diminuição no valor inicial se deve à energia transportada pelos pulsos, logo,

$$
E_{1}=E_{0}-E
$$

onde, $E_{1}$ é a energia total final do corpo após a emissão dos pulsos e $E$, a energia transportada pelos pulsos. 
Para um observador que se encontra no referencial S', o corpo possui energia cinética antes e após a emissão dos pulsos. Utilizando a teoria relativística para o Efeito Doppler da luz (obtida por Einstein no artigo sobre os postulados da TRR), temos que, se $E$ é a energia da onda eletromagnética medida em $\mathrm{S}$, em S' sua energia $E^{\prime}$ será:

$$
E^{\prime}=E \gamma\left(1-\frac{v}{c}\right)
$$

Usando a equação (28) encontramos que a energia inicial do corpo medida em S' será de:

$$
E_{1}^{\prime}=E_{0}^{\prime}-\gamma E
$$

Agora subtraindo a equação (29) da equação (27), temos:

$$
\left(E_{0}^{\prime}-E_{0}\right)-\left(E_{1}^{\prime}-E_{1}\right)=E(\gamma-1)
$$

Analisando os termos acima, temos que, $\left(E_{0}^{\prime}-E_{0}\right)$ é a diferença entre a energia mecânica inicial medida em $S^{\prime}$ e a medida em $S$, logo, $\left(E_{1}^{\prime}-E_{1}\right)$ é a diferença entre as energias mecânicas finais em S' e S. Como o corpo não possui energia cinética no referencial $S$, tem-se que, $\left(E_{0}^{\prime}-E_{0}\right)$ corresponde à energia cinética inicial do corpo medida em $\mathrm{S}^{\prime}$, e de modo análogo, $\left(E_{1}^{\prime}-E_{1}\right)$ é a medida da energia cinética após as emissões medida em $S^{\prime}$. Os valores de $\left(E_{0}^{\prime}{ }_{0}-E_{0}\right)$ e $\left(E_{1}^{\prime}-E_{1}\right)$ são acrescidos de uma constante aditiva que não depende das emissões em si, mas do sistema de unidades utilizado.

Desse modo a equação (30) pode ser reescrita como:

$$
K_{0}^{\prime}-K^{\prime}=E(\gamma-1)
$$

Agora, se considerarmos $v \ll c$, e expandindo o fator de Lorentz $(\gamma)$ em série de potências de $\left(\frac{v}{c}\right)$, e adotarmos apenas os dois primeiros termos da série, a relação acima será:

$$
K_{0}^{\prime}-K^{\prime}=\frac{1}{2}\left(\frac{E}{c^{2}}\right) v^{2}
$$


Portanto, a energia transportada pelos pulsos é igual a uma energia cinética (não relativística) que possui uma massa equivalente a $\left(\frac{E}{c^{2}}\right)$. Generalizando o resultado encontrado para emissões de qualquer natureza, Einstein conclui que:

Se um corpo perder energia $E$ em forma de radiação, sua massa sofre uma diminuição $\left(\frac{E}{c^{2}}\right)$. É claro que nada importa se a transformação da energia perdida pelo corpo em energia da radiação é direta ou não, de modo que somos levados às seguintes conclusões gerais: A massa de um corpo é uma medida do seu conteúdo energético; se a energia sofrer uma variação igual a $E$, sua massa sofrerá, ao mesmo tempo, uma variação igual a $\left(\frac{E}{c^{2}}\right)$. (EINSTEIN, apud OSTERMANN, 2004, p.93)

Dessa forma a equivalência massa-energia é expressa pela relação:

$$
E_{0}=m c^{2}
$$

A equação acima frequentemente é interpretada de forma equivocada, considerando que massa e energia constituem a mesma grandeza, e que podem ser convertidas uma na outra. De acordo com Ostermann (2004), essa interpretação pode conduzir a um entendimento de que, se existe energia, existe massa, o que induz a pensar que o fóton por possuir energia, possui também massa.

Sem dúvidas, a Teoria da Relatividade Restrita proporcionou uma revolução científica, redefinindo conceitos e concepções estruturantes da Física. "Einstein ligou não apenas o espaço e o tempo, mas também massa com energia", Hewitt (2015, p.678).

A equação $E_{0}=m c^{2}$ é considerada por muitos a mais famosa do século $X X$, não só por sua importância na ciência, mas também por ser objeto de divulgação científica da Teoria da Relatividade Restrita nas mídias e constituir, muitas vezes, o primeiro ou único contato do público leigo com essa teoria. 


\section{PROCEDIMENTOS METODOLÓGICOS}

Este capítulo tem por finalidade apresentar a metodologia utilizada na sequência didática aplicada. Abordamos um pouco da Pesquisa Qualitativa no intuito de fundamentar nossa investigação e outros aspectos metodológicos envolvidos, apresentando a organização e a coleta dos dados da aplicação dessa sequência didática.

\subsection{AS CARACTERÍSTICAS DA PESQUISA QUALITATIVA}

A pesquisa qualitativa é um tipo de investigação em que o foco está mais no processo do que no resultado, o que se busca é compreender o fenômeno estudado. A pesquisa qualitativa difere da quantitativa em seu objetivo, que não é medir nem criar estatísticas: a coleta de dados é descritiva.

Lüdke e André (1986) defendem as abordagens qualitativas de pesquisa como sendo alternativas mais convenientes para a análise dos fenômenos educacionais. De acordo com as autoras citadas, com o desenvolvimento das pesquisas em educação,

foi-se percebendo que poucos fenômenos nessa área podem ser submetidos a esse tipo de abordagem analítica, pois em educação as coisas acontecem de maneira tão inextricável que fica difícil isolar as variáveis envolvidas e mais ainda apontar claramente quais são as responsáveis por determinado efeito (LÜDKE e ANDRÉ, 1986, p.3)

Segundo Bogdan e Biklen (1994), os investigadores qualitativos em educação procuram ao longo de suas investigações, se certificarem de que estão aprendendo as diferentes perspectivas adequadamente. Ao exercerem o papel de questionadores, buscam perceber o que estes sujeitos investigados experimentam e como interpretam as suas experiências, e as estruturam, no mundo social em que vivem:

Os investigadores qualitativos estabelecem estratégias e procedimentos que lhes permitam tomar em consideração as experiências do ponto de vista do informador. O processo de condução de investigação qualitativa reflete uma espécie de diálogo entre os investigadores e os respectivos sujeitos, dado estes não serem abordados por aqueles de uma forma neutra. (BOGDAN; BIKLEN, p.51, 1994). 
Dessa forma, Rossman e Rallis (1998, apud. Creswell, 2007) listam as seguintes características, que devem estar presentes na pesquisa qualitativa:

- A pesquisa qualitativa ocorre em um cenário natural, de forma que o pesquisador vai até o participante, o que permite uma melhor visão e envolvimento do pesquisador com o participante;

- A pesquisa qualitativa utiliza-se de múltiplos métodos de coletas de dados (imagens, palavras, textos, vídeos), que são interativos e humanísticos, e buscam estabelecer harmonia e credibilidade com as pessoas no estudo;

- Uma parte considerável da pesquisa qualitativa surge durante o próprio estudo, podendo as questões de pesquisa mudar e ser refinadas, o processo de coleta de dados pode se alterar para se adequar a novas situações, como dados que se disponibilizam e dados que deixam de estar disponíveis etc.;

- A pesquisa qualitativa é fundamentalmente interpretativa, ou seja, ela surge da interpretação que o pesquisador faz dos dados coletados;

- A pesquisa qualitativa fornece uma visão ampla e abrangente dos fenômenos, ao invés de microanálises;

- O pesquisador qualitativo adota uma ou mais estratégias de investigação em seu estudo.

Com base na breve descrição das características da pesquisa qualitativa vamos, a seguir, descrever o contexto, os sujeitos da pesquisa e os aspectos metodológicos da coleta e da análise dos dados.

\subsection{ESTRATÉGIAS DESENVOLVIDAS NA PESQUISA E ESTRUTURA DA SEQUÊNCIA DIDÁTICA}

O produto dessa dissertação foi elaborado com base nas metodologias, conceitos e referenciais descritos anteriormente. Com o auxilio de diferentes estratégias e recursos de ensino (questionários, vídeos, músicas, textos, exercícios e atividades em grupos) propusemos ensinar alguns tópicos da Teoria da Relatividade Restrita.

Nesta proposta didática, as aulas foram expositivas dialógicas, contextualizadas e orientadas pela interação aluno - professor - conhecimento. As atividades foram desenvolvidas ao longo de sete aulas, sendo realizada uma aula por semana com duração de aproximadamente 45 minutos. A estrutura da 
sequência didática, com a distribuição das aulas, juntamente com os seus objetivos, estão descritos no Quadro 1.

Quadro 1 - Descrição dos tópicos abordados na sequência didática.

\begin{tabular}{|c|c|c|}
\hline AULA & TÓPICO & OBJETIVO EDUCACIONAL \\
\hline Aula 1 & Questionário Investigativo & $\begin{array}{l}\text { Verificação do conhecimento prévio } \\
\text { dos alunos por meio de um } \\
\text { questionário investigativo. }\end{array}$ \\
\hline Aula 2 & Espaço & $\begin{array}{l}\text { Localizar pontos no espaço Euclidiano. } \\
\text { Familiarizar-se com o uso de } \\
\text { referenciais no espaço. Estabelecer a } \\
\text { diferença entre espaço e distância. }\end{array}$ \\
\hline Aula 3 & Tempo & $\begin{array}{l}\text { Abordar o conceito de tempo e as } \\
\text { diversas maneiras de medi-lo. Discutir } \\
\text { as diferenças entre tempo emocional e } \\
\text { tempo físico. }\end{array}$ \\
\hline Aula 4 & $\begin{array}{lcc}\text { Postulados } & \text { da } & \text { Teoria } \\
\text { Relatividade } & \text { Restrita (TRR). }\end{array}$ & $\begin{array}{l}\text { Apresentar os postulados da TRR: } \\
\text { Invariância das leis Físicas e } \\
\text { Constância da Velocidade da luz. } \\
\text { Referenciais Inerciais. }\end{array}$ \\
\hline Aula 5 & $\begin{array}{l}\text { Dilatação do tempo e contração do } \\
\text { espaço. }\end{array}$ & $\begin{array}{l}\text { Conceitos dilatação do tempo e } \\
\text { contração do espaço com suas } \\
\text { respectivas equações. } \\
\text { Correção relativística no GPS. }\end{array}$ \\
\hline Aula 6 & Relação Massa Energia & $\begin{array}{l}\text { Apresentar a equação } \mathrm{E}=\mathrm{mc}^{2} \text {. } \\
\text { Mostrar usos e consequências: } \\
\text { energia nuclear e bomba atômica. }\end{array}$ \\
\hline Aula 7 & Avaliação & $\begin{array}{l}\text { Verificação da aprendizagem dos } \\
\text { alunos por meio de um questionário. }\end{array}$ \\
\hline
\end{tabular}

Fonte: Elaborado pela autora.

Para que os objetivos fossem alcançados, para cada aula foi proposto adotar uma estratégia de ensino que conduzisse os alunos a serem protagonistas no processo de aprendizagem.

Inicialmente, ao responderem o questionário investigativo, os conhecimentos prévios dos alunos foram verificados e, dessa forma, foi possível fazer um levantamento por meio das respostas dadas de qual era o nível de conhecimento a respeito da Teoria da Relatividade, de cada aluno. Na segunda aula a noção de espaço foi trabalhada utilizando um sistema de coordenadas, a fim de que os alunos conseguissem localizar pontos no espaço e distinguir a noção de espaço e distância. Na terceira aula, onde abordamos o conceito de 
tempo, procuramos apresentá-lo de uma maneira mais informal: para isso, empregamos, como recursos didáticos, a apresentação de um vídeo e de uma música, com diferentes interpretações sobre a temática tempo. Para a apresentação dos postulados da TRR, na quarta aula, utilizamos um vídeo que apresenta a teoria na forma de uma conversa de fácil entendimento entre amigos. Já a estratégia usada na quinta aula foi trazer uma aplicação da TRR para tratamos dos efeitos da dilatação temporal e a contração do espaço. Para isso, analisamos um infográfico sobre o funcionamento de GPS. Na sexta aula, a relação massa-energia foi apresentada e por meio da leitura e interpretação de textos impressos, analisamos como o uso de tal relação, no caso apresentado, a bomba atômica, pode nos trazer consequências. Por fim, na última aula proposta para a sequência didática, os alunos fizeram uma avaliação escrita. A avaliação foi desenvolvida em grupos onde os alunos puderam verbalizar e discutir sobre as questões.

É importante ressaltar que a avaliação da aprendizagem é um processo contínuo. Portanto, no decorrer de toda a aplicação da sequência didática a avaliação também aconteceu. As respostas dadas pelos alunos, ao final de cada aula, demonstram se algum conhecimento foi assimilado, por cada um.

Destacamos ainda que, as aulas e os temas propostos nesta sequência didática não abrangem a totalidade da Teoria da Relatividade Restrita. Por meio dos conteúdos escolhidos, o que pretendemos foi otimizar, tornar mais interessante e acessível, uma abordagem de tópicos da Teoria da Relatividade Restrita.

A seguir, será apresentada uma breve discussão sobre as aulas. Todas as atividades citadas se encontram no Apêndice A (p.96), que constitui o produto educacional desta dissertação. 


\section{A APLICAÇÃO DA SEQUÊNCIA DIDÁTICA}

A sequência didática elaborada foi aplicada em uma turma do $3^{\circ}$ ano da Educação de Jovens e Adultos (EJA), de uma escola pública localizada no município de Juiz de Fora. Tal escola tem boa aceitação para a realização de projetos, em todas as disciplinas da grade curricular.

A EJA é uma modalidade de ensino cujo objetivo é permitir que pessoas adultas, que não tiveram a oportunidade de frequentar a escola na idade convencional, possam retomar seus estudos. Para se cursar o Ensino Médio na EJA, é preciso ter idade mínima de 18 anos, e para concluir o ensino médio o aluno estuda 1 ano e meio, pois cada ano ou série do ensino regular pode ser concluída em módulos de seis meses. As aulas são diárias, de segunda à sextafeira e o curso conta com quatro horas de duração.

As aulas dessa sequência didática foram realizadas no horário normal da EJA (período noturno) durante os meses de setembro e outubro de 2019. A turma era composta por 28 alunos, com idades entre 18 e 41 anos. Além da diversidade na faixa etária, foi possível observar diferentes níveis de conhecimentos escolares e também de interesse na aquisição de novos conhecimentos. Tais fatores proporcionaram obter dos alunos diferentes concepções, visões e opiniões a respeito dos tópicos de Física abordados.

Com o objetivo de desenvolver nos alunos uma compreensão acerca da Teoria da Relatividade Restrita, a sequência didática elaborada e aplicada é composta por sete aulas, com duração de aproximadamente 45 minutos cada.

Durante as aulas foram aplicadas diferentes estratégias de ensino como vídeos, músicas, textos, discussões, trabalhos em grupo, atividades individuais e questionários, com o intuito de proporcionar aos alunos mecanismos que conduzam a uma aprendizagem significativa da Teoria da Relatividade Restrita.

A seguir, faremos uma descrição detalhada de cada aula que compõe a sequência didática.

Aula 1 - Questionário de Sondagem

A aula iniciou-se com uma explicação sobre a proposta didática que seria desenvolvida ao longo das sete aulas. Um fato bem interessante ocorreu ao se mencionar que o conteúdo a ser tratado nas próximas aulas tinha relação com 
Albert Einstein: um aluno perguntou: "mas será que vou conseguir entender uma coisa que Einstein inventou?". A partir dessa fala percebemos o quanto aprender algo relacionado a Einstein parece desafiador aos alunos.

Logo em seguida foi explicado aos alunos que nessa primeira aula seria aplicado um questionário investigativo, e que para respondê-lo não seria permitido consultar livros, cadernos e celulares, e a professora não poderia explicar as questões, pois, a interferência poderia alterar os resultados.

O questionário composto por 10 questões (Apêndice $B, p .115$ ) tem o objetivo de fazer um levantamento dos conhecimentos prévios dos alunos acerca dos conteúdos abordados em toda a sequência didática.

A princípio, os alunos ficaram apreensivos com o questionário, falaram que não saberiam "fazer as contas", e que "não foi avisado que teria prova". Então, novamente foi explicado que não se tratava de uma prova, e que as respostas dadas serviriam para orientar o desenvolvimento das atividades.

Alguns alunos apresentaram dificuldade no entendimento e na interpretação das questões. Comentaram que não estão acostumados a pensar em questões de Física como as que foram apresentadas. Isso reflete o fato das aulas de Física serem ministradas objetivando quase sempre apenas a resolução numérica de exercícios.

Ao final da aula, após a entrega do questionário, os alunos começaram a conversar, querendo saber o que os colegas tinham respondido. Foi um momento bem construtivo, pois, gerou uma discussão pela defesa das respostas divergentes.

\section{Aula 2 - Espaço}

No início da aula foi solicitado aos alunos que formassem grupos com quatro integrantes. Foi entregue a cada grupo os seguintes materiais: um aparato de três eixos ortogonais feitos de isopor e papel milimetrado, alfinetes e varetas coloridas. A seguir, foi proposto a cada grupo o desafio de representar, no seu aparato, a posição em que se encontravam alguns objetos que foram colocados pela professora em alguns pontos da sala. Os objetos eram: uma folha de cor branca colada no quadro, uma caixa de sapatos no chão da sala, uma folha de cor 
azul colada em uma das paredes laterais e a uma caneta pendurada no teto por um fio.

Foi questionado aos alunos: como localizar tais objetos usando o aparato como um sistema de referência? Para direcionar a atividade foi feita uma breve explicação sobre referencial cartesiano e coordenadas cartesianas. A seguir, cada grupo atuou livremente na escolha da posição do seu sistema de referência, apenas interferi quando fui solicitada.

A maioria dos grupos localizou com facilidade a folha colada no quadro, a caixa no chão da sala e a folha em uma das paredes. Para isso, utilizaram os alfinetes coloridos. Todos os grupos apresentaram bastante dificuldade em localizar a caneta pendurada por um fio. Inicialmente, apenas um grupo conseguiu fazer, utilizando as varetas coloridas. Depois de verem como foi feita a atividade pelo grupo que concluiu primeiro, os demais também fizeram.

Finalizamos a aula de forma dialogada descrevendo o conceito de referencial e desconstruindo o conceito físico de que espaço é sinônimo de distância. Como atividade complementar (Apêndice C, p.117) cada grupo deveria responder por escrito e trazer para a próxima aula a seguinte pergunta: Quantas dimensões existem no espaço em que vivemos e como podemos localizar a posição de um objeto no espaço?

\section{Aula 3 - Tempo}

A aula iniciou-se com a apresentação do trecho de um vídeo de uma série de divulgação científica intitulada "Além do Cosmos".

"Além do Cosmos" é uma série produzida pelo National Geographic Channel no ano de 2012, baseada no livro, "O Tecido do Cosmo: Espaço, Tempo e Textura da Realidade" (The Fabric of the Cosmos: Space, Time, and the Texture of Reality, 2005), do físico Brian Greene. Ela é composta por quatro episódios de 60 minutos cada, que nos levam às fronteiras da física para entender como cientistas estão montando um quadro mais completo do espaço, tempo e do universo.

Apresentamos aos alunos uma parte do Episódio: Tempo Distorcido (Time Warp), disponível em: https://www.youtube.com/watch?v=6munxHulhgs. O trecho do vídeo apresentado tem duração de aproximadamente 8 minutos (os primeiros 8 minutos do episódio), e aborda como o tempo tem sido medido ao longo da 
história. Também apresenta a importante questão de que o tempo pode ser medido de diferentes maneiras, mas ainda é difícil responder o que é o tempo. $O$ trecho termina com a apresentação do conceito de tempo nas visões de Newton e de Einstein, inserindo a Teoria da Relatividade.

Após a exibição do vídeo foram feitos comentários sobre alguns tópicos, tais como, a definição da divisão do dia em horas e dos meses do ano.

A seguir, para discutir sobre o significado de tempo e as diferenças entre tempo emocional e tempo físico foi apresentada uma música "Semana que vem Pitty". Os alunos escutaram a música e receberam uma atividade com questões (Apêndice D, p.118) relativas ao tema, que deveriam ser respondidas.

Aula 4 - Postulados da Teoria da Relatividade Restrita

Essa aula teve o objetivo de inserir os postulados da Teoria da Relatividade Restrita. Para isso, os alunos assistiram a um vídeo que está disponível em: https://www.youtube.com/watch?v=nf32ejhzTNQ. O vídeo tem duração de aproximadamente 15 minutos. Apresentando uma linguagem de fácil entendimento e exemplos muito explicativos, o vídeo aborda pontos importantes da Teoria da Relatividade Restrita. Após a exibição, deu-se prosseguimento da aula, de forma dialogada, com o auxilio do quadro para anotações e explanação dos conceitos e conteúdos, tais como:

- Repouso e movimento dependem do referencial;

- Referencial inercial;

- Composição de velocidades;

- Constância da velocidade da luz;

- Os postulados da Teoria da Relatividade;

- Espaço e tempo (absolutos de Newton x relativos de Einstein);

- Efeitos relativísticos observados somente com velocidades próximas à da luz.

No decorrer da aula foi possível retomar algumas perguntas feitas no questionário investigativo e discutir as respostas com base nos conteúdos da aula.

Aula 5 - Dilatação do tempo e contração do espaço

No início da aula foi feita uma revisão dos conteúdos e conceitos abordados na aula anterior. Os postulados da Teoria da Relatividade Restrita foram 
novamente enunciados e, dando prosseguimento, foram discutidos os efeitos da contração do espaço e da dilatação do tempo e, a seguir, apresentadas suas respectivas equações e resolvidos exercícios envolvendo situações relativísticas. Alguns alunos apresentaram dificuldade na resolução matemática dos exercícios. Após essas resoluções, os alunos receberam um texto de divulgação científica (Anexo B, p.122) e um infográfico (Anexo C, p.124) sobre o funcionamento do GPS. Fizemos uma leitura do texto e análise das informações, e alguns alunos demonstraram bastante surpresa ao descobrir a necessidade do uso da Teoria da Relatividade para a precisão daquele equipamento.

\section{Aula 6 - Relação Massa Energia}

Nessa aula abordamos a equação $E=m \cdot c^{2}$, por meio de um material de apoio impresso.

No início da aula, a equação foi escrita no quadro, e foi perguntado quem já tinha visto tal equação. Apenas dois alunos responderam que já tinham visto. Também foi perguntado qual era o significado de cada letra, e alguns alunos responderam corretamente que $\mathrm{m}$ representava massa, e c a velocidade da luz. Após esse momento, os alunos receberam o material para a aula impresso e realizaram uma leitura do texto. A seguir, a professora realizou a leitura do texto Massa e Energia (Anexo D, p.125) fazendo uma explanação do tema, juntamente com a realização dos cálculos. Seguindo a aula, analisamos o outro texto, A Energia Nuclear e a Bomba Atômica (Anexo E, p.126). Através dos dados fornecidos pelo texto, os alunos conheceram o poder destruidor da bomba atômica e como atividade, resolveram alguns problemas propostos.

\section{Aula 7 - Avaliação}

$\mathrm{Na}$ última aula da sequência didática, foi aplicado um questionário (Apêndice E, p.119) para verificação da aprendizagem dos conteúdos apresentados e estudados.

Como, durante toda a aplicação da sequência didática, foi possível observar que as atividades realizadas em grupos promoviam um ambiente mais favorável à aprendizagem, optamos por realizar a avaliação dos alunos nos seus respectivos grupos. Cada aluno recebeu sua folha com o questionário, mas, para respondê-lo, puderam trocar opiniões e discutir ideias. Foi possível observar a 
argumentação dos alunos em busca das respostas das questões. $O$ fato de defenderem uma resposta como a correta e apresentarem argumentos na explicação para o colega que não entendeu, já demonstra o conhecimento que foi absorvido pelo aluno.

Durante a avaliação, alguns alunos solicitaram o auxilio da professora, mas, conforme foi explicado no início da aula, não haveria interferência com ajuda na resolução das questões. Em alguns casos, foi feita a leitura da questão para ajudar na interpretação. Ao final da aula, todos os alunos devolveram o questionário respondido.

Após finalizar a aplicação da sequência didática, algumas considerações são importantes a se fazer. Durante as aulas foi possível perceber o envolvimento de grande parte dos estudantes nas atividades e os recursos e estratégias educacionais empregados de certa forma foram facilitadores na compreensão dos conceitos relacionados à Teoria da Relatividade Restrita. Esses e outros aspectos da aplicação da sequência didática serão discutidos e analisados no próximo capítulo. 


\section{ANÁLISE DOS RESULTADOS}

Neste capítulo vamos analisar os dados coletados durante a aplicação da sequência didática. Por questões éticas não serão citados os nomes dos alunos sendo chamados por números (A1; $A 2 ; \ldots ; A n)$ ou ainda, os grupos $(G 1 ; G 2 ; \ldots ;$ Gn). Conforme descrito anteriormente, utilizamos a pesquisa qualitativa como metodologia na aplicação da sequência didática. Dessa forma, aplicamos como instrumento avaliativo a produção textual, que nos permite observar como os alunos expressam o que sabem ou o que entenderam por meio da escrita. Para isso, usamos um questionário investigativo, os escritos produzidos durante e ao término das atividades desenvolvidas e também uma avaliação final.

Para a organização e análise dos dados coletados durante a aplicação da sequência didática, utilizamos a teoria de Análise de Conteúdo descrita por Laurence Bardin (2011) por meio da obra a L'analyse de contenu.

Para Bardin (2011), o termo análise de conteúdo designa:

um conjunto de técnicas de análise das comunicações visando a obter, por procedimentos sistemáticos e objetivos de descrição do conteúdo das mensagens, indicadores (quantitativos ou não) que permitam a inferência de conhecimentos relativos às condições de produção/recepção (variáveis inferidas) destas mensagens (Bardin, 2011, p.47).

Segundo Bardin (2011), a Análise de Conteúdo é uma técnica que trabalha os dados coletados com o objetivo de identificar o que está sendo dito a respeito de determinado tema. É um instrumento de exploração interpretativo que pode ser aplicado em análises quantitativas ou qualitativas. Na pesquisa quantitativa, o que serve de informação é a frequência com que surgem certas características do conteúdo. Já na pesquisa qualitativa é a presença ou a ausência de uma dada característica do conteúdo ou de um conjunto de características, num determinado fragmento de mensagem, que é levado em consideração.

Uma vez que a sequência didática aplicada visa tornar o estudo da Teoria da Relatividade Restrita mais acessível e compreensível aos alunos do Ensino Médio, a análise de conteúdo mostra-se aplicável como estratégia de pesquisa, visto que, propomos que a aprendizagem aconteça num contexto de interpretação e contextualização das concepções e conceitos da TRR. A seguir analisaremos as atividades aplicadas em cada aula da sequência didática. 


\subsection{AULA 1 - QUESTIONÁRIO DE SONDAGEM}

$\mathrm{Na}$ primeira aula da SD foi solicitado aos alunos que respondessem a um questionário contendo 10 questões tratando de conceitos relacionados à Teoria da Relatividade. O questionário encontra-se no Apêndice B (p.115). O objetivo deste questionário era investigar acerca dos conhecimentos prévios dos alunos. Faremos a seguir uma análise de cada uma das questões. As respostas estão apresentadas em quadros e foram categorizadas em padrões de respostas.

A primeira pergunta do questionário contém duas partes. A primeira parte diz respeito ao conceito de espaço e é apresentada no Quadro 2.

Quadro 2 - Questionário de Sondagem: Questão 1.A

\begin{tabular}{|c|c|c|}
\hline Categoria & $\begin{array}{l}\text { Número de } \\
\text { respostas }\end{array}$ & Exemplos de respostas \\
\hline $\begin{array}{l}\text { Distância entre dois } \\
\text { lugares (pontos) }\end{array}$ & 3 & $\begin{array}{c}\text { "aquilo que separa cada coisa" (A27) } \\
\text { "uma distância" (A12) }\end{array}$ \\
\hline Espaço Sideral & 5 & $\begin{array}{c}\text { "Um lugar onde tem os planetas." (A23) } \\
\text { "O céu, as estrelas, a lua, o sol” (A6) } \\
\text { "o espaço da galáxia” (A28) }\end{array}$ \\
\hline $\begin{array}{l}\text { Região (meio) em que } \\
\text { estamos }\end{array}$ & 7 & $\begin{array}{c}\text { "É tudo que está a nossa volta" (A11) } \\
\text { "Onde está qualquer coisa” (A16) } \\
\text { “Onde nós seres humanos habitamos" (A20) } \\
\text { "É o meio físico onde estamos" (A17) }\end{array}$ \\
\hline Uma região vazia & 5 & $\begin{array}{c}\text { "é um local vazio" (A1) } \\
\text { "algo que não tem ocupação por nada" (A2) }\end{array}$ \\
\hline $\begin{array}{l}\text { Ideia de lugar } \\
\text { (localidade) }\end{array}$ & 7 & $\begin{array}{l}\text { "são lugares para serem ocupados" (A15) } \\
\text { "um lugar onde um corpo habita" (A19) } \\
\text { "um lugar onde pode ou poderia ser ocupado" (A4) }\end{array}$ \\
\hline Ideia de infinito & 1 & $\begin{array}{c}\text { "O espaço pode ser infinito, pois não sabemos até onde } \\
\text { se pode ir." (A18) }\end{array}$ \\
\hline
\end{tabular}

Fonte: Elaborado pela autora.

O objetivo da primeira parte da pergunta inicial era fazer com que os alunos descrevessem o que eles entendem por espaço. Ao responderem, eles expressaram seus conhecimentos de muitas formas. 
Três alunos associaram espaço à ideia de separação entre corpos ao responderam que espaço é a distância entre dois pontos. Na segunda categoria, cinco alunos apresentaram respostas dizendo que espaço era a região do espaço sideral, onde estão os planetas, as estrelas, a lua, etc. Provavelmente atribuíram esse significado ao fato de espaço sideral ser mencionado apenas como espaço.

Sete alunos aparecem na terceira categoria, respostas que de algum modo diziam que espaço é o que nos cerca ou o meio em que estamos. Em particular, o aluno A17 usou o termo meio físico para se referir ao conceito. A quarta categoria concentra as respostas de cinco alunos, que expressaram o espaço como uma região vazia, como por exemplo, uma sala sem nenhum objeto. Neste grupo de respostas, a ideia de região vazia não fez alusão à ideia de vácuo.

$\mathrm{Na}$ quinta categoria, agrupamos as respostas que trouxerem o espaço como um lugar, uma região bem definida. Percebe-se, pelos escritos dos sete alunos, que eles usaram o conceito de espaço geográfico para construir suas respostas. Por fim, a última categoria traz a resposta do aluno $A 18$, que atribuiu ao espaço a ideia de infinito. Na afirmação do aluno não ficou muito claro se ele quis fazer referência ao conceito de espaço sideral

A segunda parte da primeira pergunta diz respeito ao conceito de tempo e é apresentada no Quadro 3. O objetivo da pergunta é saber qual é o conceito de tempo na visão dos alunos.

As respostas dadas pelos 28 alunos foram divididas em cinco categorias. A diferença do número total de respostas e o número de alunos se deve ao fato de que muitas das respostas se enquadram em mais de uma categoria.

A primeira categoria, com oito alunos, apresentou respostas que caracterizavam o tempo como uma medida, sendo esta, fornecida pelo relógio ou pelo calendário. A segunda categoria, com 9 alunos, descreveu o tempo com qualidades meteorológicas. A presença da característica meteorológica nas respostas reflete o fato de se ouvir cotidianamente o termo "previsão do tempo" em telejornais e internet. Já o terceiro grupo de alunos descreveu que o tempo é a duração de um determinado acontecimento, ou o intervalo de tempo para que algo aconteça. Na quarta categoria, os alunos apresentaram como respostas o caráter cronológico do tempo, evidenciando a ideia de passagem do tempo, por meio de afirmações que expressam o pensamento de passado, presente e futuro. $\mathrm{Na}$ 
última categoria, foram agrupadas as respostas que descreveram o tempo como algo contínuo, que flui constantemente e não para.

\section{Quadro 3 - Questionário de Sondagem: Questão 1.B}

\begin{tabular}{|c|c|c|}
\hline Categoria & $\begin{array}{l}\text { Número de } \\
\text { respostas }\end{array}$ & Exemplos de respostas \\
\hline $\begin{array}{l}\text { A medida do } \\
\text { relógio }\end{array}$ & 8 & $\begin{array}{l}\text { "é a hora, os minutos, os segundos" (A12) } \\
\text { "é nossa noção de dia e noite" (A27) } \\
\text { "é a contagem das horas, do mês, dos anos" (A1) }\end{array}$ \\
\hline O clima & 9 & $\begin{array}{c}\text { "é o tempo chuvoso ou ensolarado" (A11) } \\
\text { "é usado para definir o clima" (A15) }\end{array}$ \\
\hline $\begin{array}{l}\text { Duração de um } \\
\text { evento }\end{array}$ & 10 & $\begin{array}{l}\text { "tudo que tem uma duração" (A10) } \\
\text { "são os momentos vividos" (A14) } \\
\text { "é a duração de acontecimentos e fatos" (A21) }\end{array}$ \\
\hline Ideia cronológica & 7 & $\begin{array}{c}\text { "é a forma de saber que estamos envelhecendo" (A8) } \\
\text { "é o decorrer da vida" (A12) } \\
\text { "presente, passado e futuro" (A3) }\end{array}$ \\
\hline $\begin{array}{l}\text { Ideia de Fluidez } \\
\text { (algo que não } \\
\text { para) }\end{array}$ & 5 & $\begin{array}{c}\text { "é uma coisa que não devemos perder, é passageiro" (A20) } \\
\text { "é algo que nós não conseguimos controlar" (A18) }\end{array}$ \\
\hline
\end{tabular}

Fonte: Elaborado pela autora.

A segunda e a terceira questão do questionário investigativo são complementos da primeira, pois, nestas questões os alunos deveriam representar de alguma forma os conceitos de espaço e tempo. O Quadro 4 apresenta a categorização das respostas da segunda questão. 
Quadro 4 - Questionário de Sondagem: Questão 2

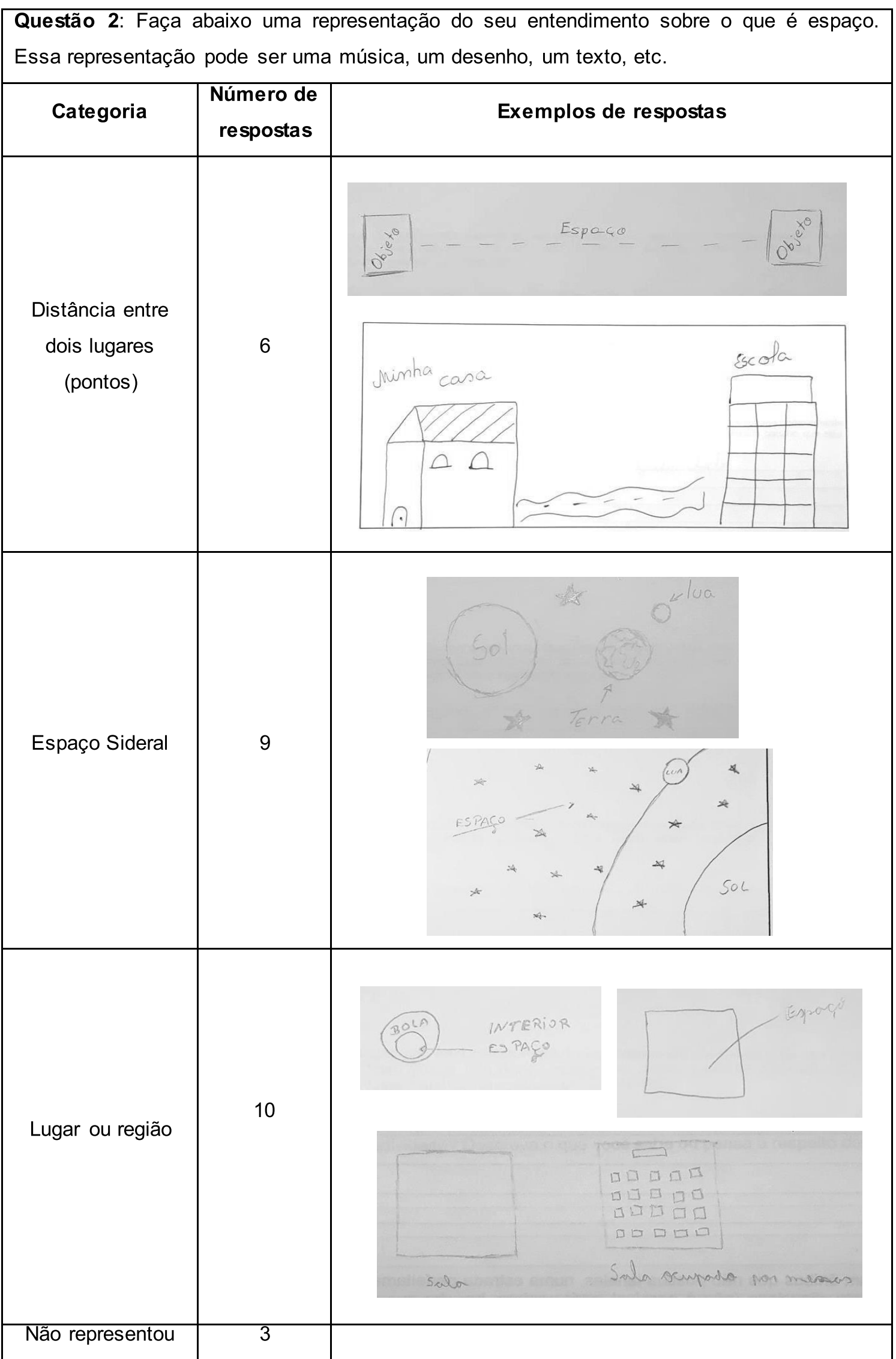

Fonte: Elaborado pela autora. 
Alguns alunos tiveram dificuldade em representar aquilo que responderam na primeira questão, dessa forma, as representações feitas foram agrupadas em apenas três categorias. Três alunos deixaram a questão em branco, sendo que, dois desles conceituaram o espaço como o meio em que estamos e o outro atribuiu ao espaço a ideia de infinito. Nove alunos apresentaram representações do espaço com o conceito de espaço sideral. As representações feitas por um grupo de dez alunos consideravam o espaço como um lugar ou uma região vazia, ou ainda um local que pode ser ocupado. Já seis representações enquadraram-se na ideia de distância ou separação entre corpos.

As representações dos alunos sobre o que é tempo descreveram suas concepções de acordo com as respostas dadas e apresentadas no Quadro 5. Do total de vinte e oito alunos, vinte e cinco fizeram as representações e todos optaram por fazê-la por meio de desenhos. Três alunos deixaram a questão em branco. O Quadro 5 apresenta a categorização das representações. Um grupo de seis alunos representou o tempo com características meteorológicas. Já a segunda categoria com o maior número de respostas (dez) apresenta as representações do tempo através de um relógio. Na terceira categoria, três alunos representaram o tempo como a duração de um evento e, na quarta categoria, apresentamos as representações dos alunos que descreveram o tempo como uma ideia cronológica, referindo-se à passagem do tempo.

Observamos que, de um modo geral, há uma coerência entre as respostas dadas na primeira questão com as representações feitas nas questões 2 e 3 , demonstrando as concepções dos alunos sobre os conceitos de espaço e tempo. Vejamos o Quadro 5. 
Quadro 5 - Questionário de Sondagem: Questão 3

Questão 3: Faça abaixo uma representação do seu entendimento sobre o que é tempo. Essa representação pode ser uma música, um desenho, um texto, etc.

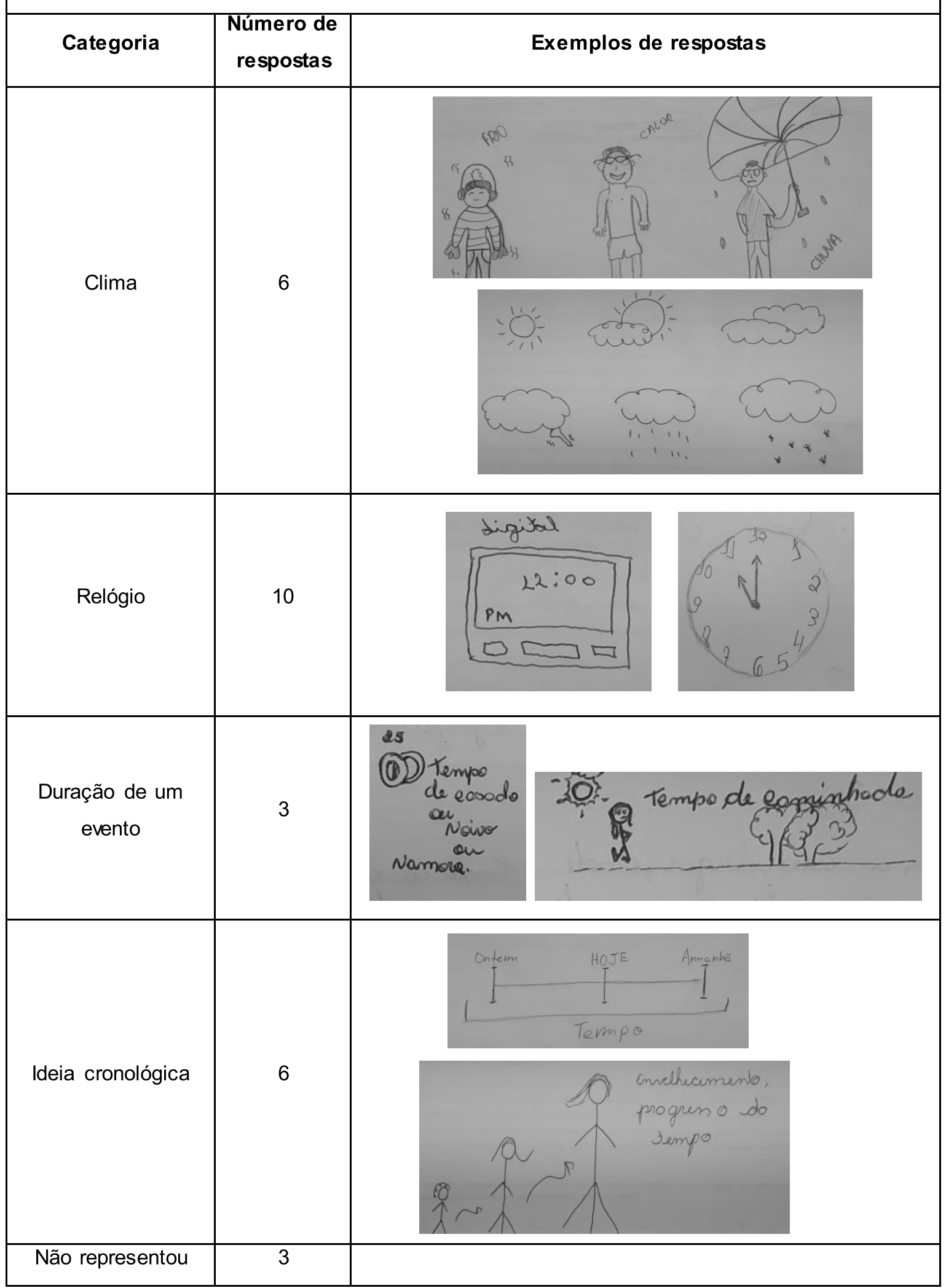

Fonte: Elaborado pela autora. 
$\mathrm{Na}$ questão número 4 do questionário, o aluno deveria descrever sobre a situação proposta envolvendo a ideia de um objeto existir no espaço e também no tempo. O Quadro 6 apresenta a categorização das respostas dadas.

\section{Quadro 6 - Questionário de Sondagem: Questão 4}

\begin{tabular}{|c|c|c|}
\hline \multicolumn{3}{|c|}{$\begin{array}{l}\text { Questão 4: Uma criança } \\
\text { ela termina sua construç } \\
\text { mesmo ocupa certo lug } \\
\text { Justifique sua resposta. }\end{array}$} \\
\hline Categoria & $\begin{array}{l}\text { Número } \\
\text { de } \\
\text { respostas }\end{array}$ & Exemplos de respostas \\
\hline $\begin{array}{c}\text { Existe por um } \\
\text { determinado } \\
\text { período }\end{array}$ & 11 & $\begin{array}{c}\text { "existe, porém não é pra sempre, tem duração, a massinha vai } \\
\text { se desfazer" (A21) } \\
\text { "Sim, mas esse carrinho um dia vai acabar, pois tudo tem um } \\
\text { tempo para habitar em nosso espaço." (A8) } \\
\text { "Ele tem uma certa duração por conta de seu material, ou seja, } \\
\text { ele teve início e terá um fim." (A1) }\end{array}$ \\
\hline $\begin{array}{l}\text { Existe no espaço } \\
\text { e no tempo }\end{array}$ & 7 & $\begin{array}{l}\text { "Sim, pois a partir de sua criação ele passa a existir no espaço } \\
\text { e no tempo." (A13) } \\
\text { "ele passou a ser inserido no tempo e no espaço" (A17) } \\
\text { "Sim. Porque a partir do momento em que ele passou a } \\
\text { existir, ele está no espaço e no tempo." (A4) }\end{array}$ \\
\hline $\begin{array}{l}\text { Já existia } \\
\text { (a matéria) }\end{array}$ & 4 & $\begin{array}{c}\text { "O formato do carro passou a existir, mas a massinha já } \\
\text { existia" (A27) } \\
\text { "Sim, mas o carrinho já existia de uma forma diferente, ele era } \\
\text { só massinha." (A23) } \\
\text { "as matérias que compõem o carrinho já existiam em algum } \\
\text { lugar no espaço" (A2) }\end{array}$ \\
\hline $\begin{array}{l}\text { Existe a partir da } \\
\text { modelagem }\end{array}$ & 3 & $\begin{array}{l}\text { "Algo passa a existir no tempo a partir de sua origem."(A22) } \\
\text { "O carrinho foi criado e aí começou a existir." (A10) }\end{array}$ \\
\hline Sem resposta & 3 & - \\
\hline
\end{tabular}

Fonte: Elaborado pela autora.

Por meio das respostas apresentadas na quarta questão, buscamos identificar se os alunos associavam uma interdependência entre espaço e tempo. As respostas foram divididas em quatro categorias. A primeira categoria apresenta as respostas de onze alunos que disseram que o carrinho existirá no tempo por um determinado período devido à validade do material de que é feito. 
$\mathrm{Na}$ segunda categoria, sete alunos afirmaram que a partir do momento que o carrinho é construído ele passa a existir no tempo e no espaço. Um grupo de quatro alunos descreveu em suas respostas que o carrinho já existia, só que de outra forma, pois a matéria de que é feito o carrinho já existia. A quarta categoria apresenta as respostas dadas por três alunos e exprimem a ideia de que o carrinho existe a partir do momento em que foi modelado. Três alunos não responderam a essa questão.

A Questão 5 do questionário tem o objetivo de averiguar se os alunos possuem a noção de referencial inercial e movimento relativo. O Quadro 7 apresenta a categorização das respostas para a Questão 5.

\section{Quadro 7 - Questionário de Sondagem: Questão 5}

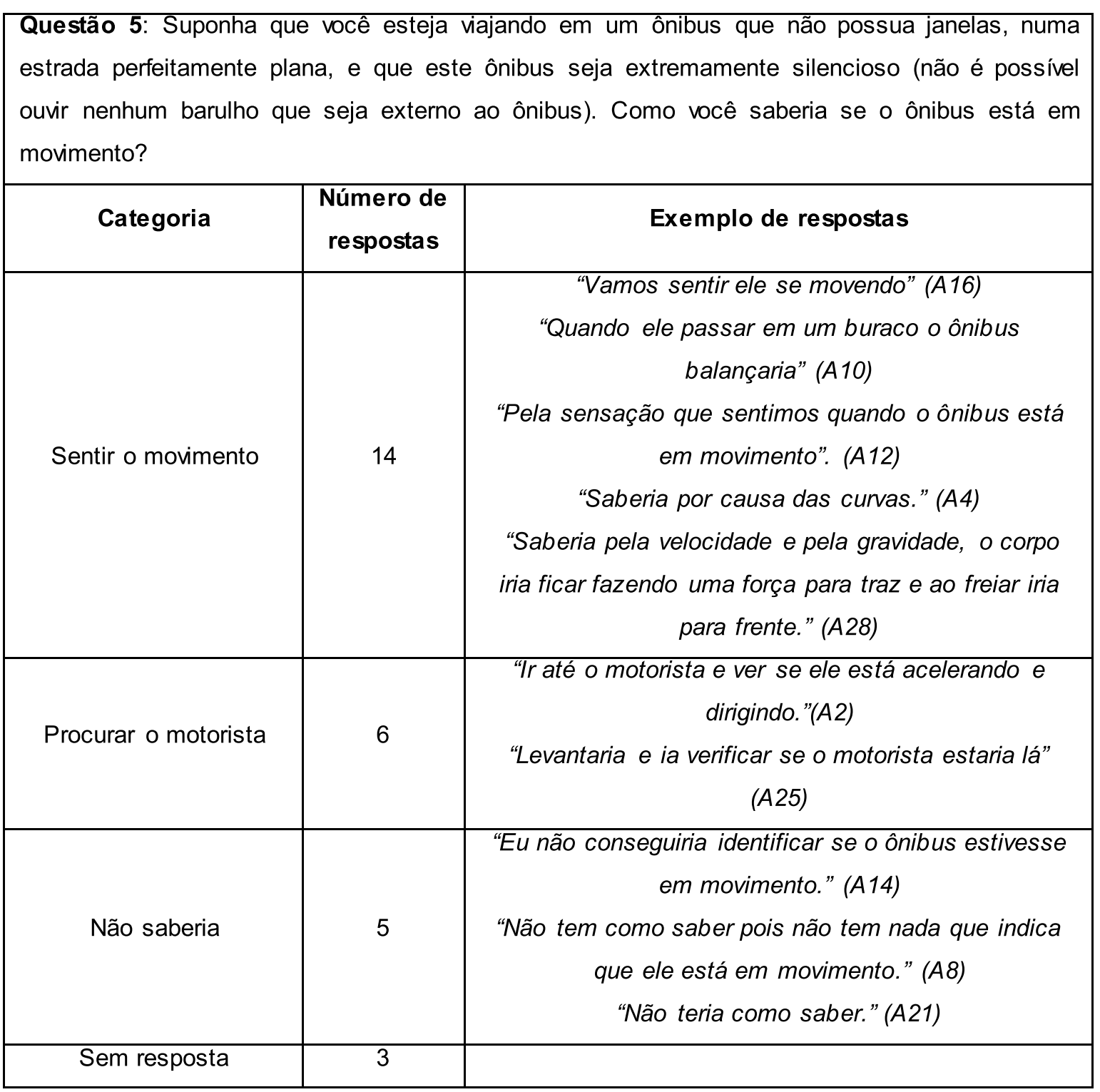

Fonte: Elaborado pela autora. 
A metade da turma (14 alunos) respondeu que seria possível perceber o movimento do ônibus por meio de alguma sensação provocada pelo deslocamento do ônibus. Um grupo de seis alunos respondeu que para constatar o movimento procurariam pelo motorista do ônibus. E cinco alunos responderam que não seria possível identificar o movimento do ônibus de acordo com a situação descrita. Três alunos não responderam a questão.

A questão 6 do questionário apresenta uma situação em que procuramos observar se os alunos conseguiam separar a noção de tempo de sua medida. As respostas dadas estão categorizadas e são apresentadas a seguir no Quadro 8.

\section{Quadro 8 - Questionário de Sondagem: Questão 6}

\begin{tabular}{|c|c|c|}
\hline \multicolumn{3}{|c|}{$\begin{array}{l}\text { Questão 6: Suponha que você esteja viajando em um ônibus onde não há relógios ou outros } \\
\text { meios de se medir o tempo. Esse ônibus não possui janelas e não há como ver se é dia ou } \\
\text { noite. Ainda assim, haveria o tempo? Qual a sua opinião sobre isso? }\end{array}$} \\
\hline Categoria & $\begin{array}{l}\text { Número de } \\
\text { respostas }\end{array}$ & Exemplo de respostas \\
\hline $\begin{array}{c}\text { Sem percepção do } \\
\text { tempo. }\end{array}$ & 8 & $\begin{array}{l}\text { "Sim, você só não vai perceber" (A10) } \\
\text { "O tempo lá fora continua, nós não teríamos noção dele." } \\
\text { (A11) } \\
\text { "Haveria o tempo. Mas não saberia se está dia ou noite." } \\
(A 6)\end{array}$ \\
\hline $\begin{array}{l}\text { Adotar alguma } \\
\text { forma de medir o } \\
\text { tempo. }\end{array}$ & 6 & $\begin{array}{c}\text { "Mesmo não vendo o dia e a noite sempre poderemos } \\
\text { contar os segundos." (A18) } \\
\text { "Haveria o tempo, eu iria pela minha intuição, se demora a } \\
\text { viagem." (A25) }\end{array}$ \\
\hline O tempo não para & 12 & $\begin{array}{c}\text { "O tempo sempre está passando, mesmo quando não } \\
\text { percebemos ou medimos." (A12) } \\
\text { "O fato de não estar sendo informado a hora, não significa } \\
\text { que o tempo não esteja passando." (A17) } \\
\text { "Não ia ter noção mas ainda sim haveria o tempo, pois ele } \\
\text { não para." (A16) } \\
\text { "O tempo estaria ali e passando eu apenas não estaria } \\
\text { vendo". (A26) }\end{array}$ \\
\hline Não respondeu & 2 & - \\
\hline
\end{tabular}

Fonte: Elaborado pela autora. 
De acordo com as respostas apresentadas no Quadro 8, é possível perceber que a maioria dos alunos entende que o tempo pode existir, mesmo quando não é possível medi-lo.

A primeira categoria apresenta as respostas de oito alunos que afirmam que existirá o tempo, mas não é possível ter a noção dele por meio de alguma medida. Na segunda categoria, seis alunos apresentaram respostas dizendo que tentariam de alguma forma medir o tempo. E um grupo de doze alunos respondeu que, mesmo sem medir, haveria o tempo, pois este não para. Dois alunos não responderam a essa questão.

O Quadro 9 traz a categorização das respostas dadas na sétima questão.

Quadro 9 - Questionário de Sondagem: Questão 7

\begin{tabular}{|c|c|c|}
\hline Categoria & $\begin{array}{c}\text { Número de } \\
\text { respostas }\end{array}$ & Exemplo de respostas \\
\hline Velocidade da luz & 17 & $\begin{array}{l}\text { "A velocidade da luz é mais rápida do que o som." (A11) } \\
\text { "Porque a luz é mais veloz que o som." (A2) } \\
\text { "Porque a velocidade da luz é maior que a do som." (A19) } \\
\text { "A luz se espalha mais rápido que o som." (A20) }\end{array}$ \\
\hline Barreira do som & 3 & $\begin{array}{c}\text { "Acontece tão rápido que rompe a barreira do som." (A22) } \\
\text { "A barreira do som tem que ser quebrada para vermos o } \\
\text { clarão." (A26) }\end{array}$ \\
\hline Raio & 5 & $\begin{array}{c}\text { "Porque o raio cai primeiro" (A6) } \\
\text { "Primeiro vem o raio depois o relâmpago da luz." }(A 7) \\
\text { "Por causa da distância que o raio cai." } A(12)\end{array}$ \\
\hline Não sei & 3 & - \\
\hline
\end{tabular}

Fonte: Elaborado pela autora.

$\mathrm{Na}$ sétima questão procuramos identificar se os alunos possuem a noção de velocidade da luz. Cerca de $60 \%$ da turma (17 alunos) respondeu corretamente a questão apresentada, mostrando conhecimento de que a velocidade da luz é maior do que a velocidade do som. Três alunos responderam que o fenômeno acontece da maneira descrita devido à barreira do som ser quebrada. E cinco alunos apresentaram respostas que associavam a ideia do barulho à queda do raio. Três alunos responderam que não sabiam responder. 
O Quadro 10 apresenta a categorização das respostas dadas na questão de número 8 que tem como objetivo fazer um levantamento do conhecimento dos alunos sobre alguns cientistas.

Quadro 10 - Questionário de Sondagem: Questão 8

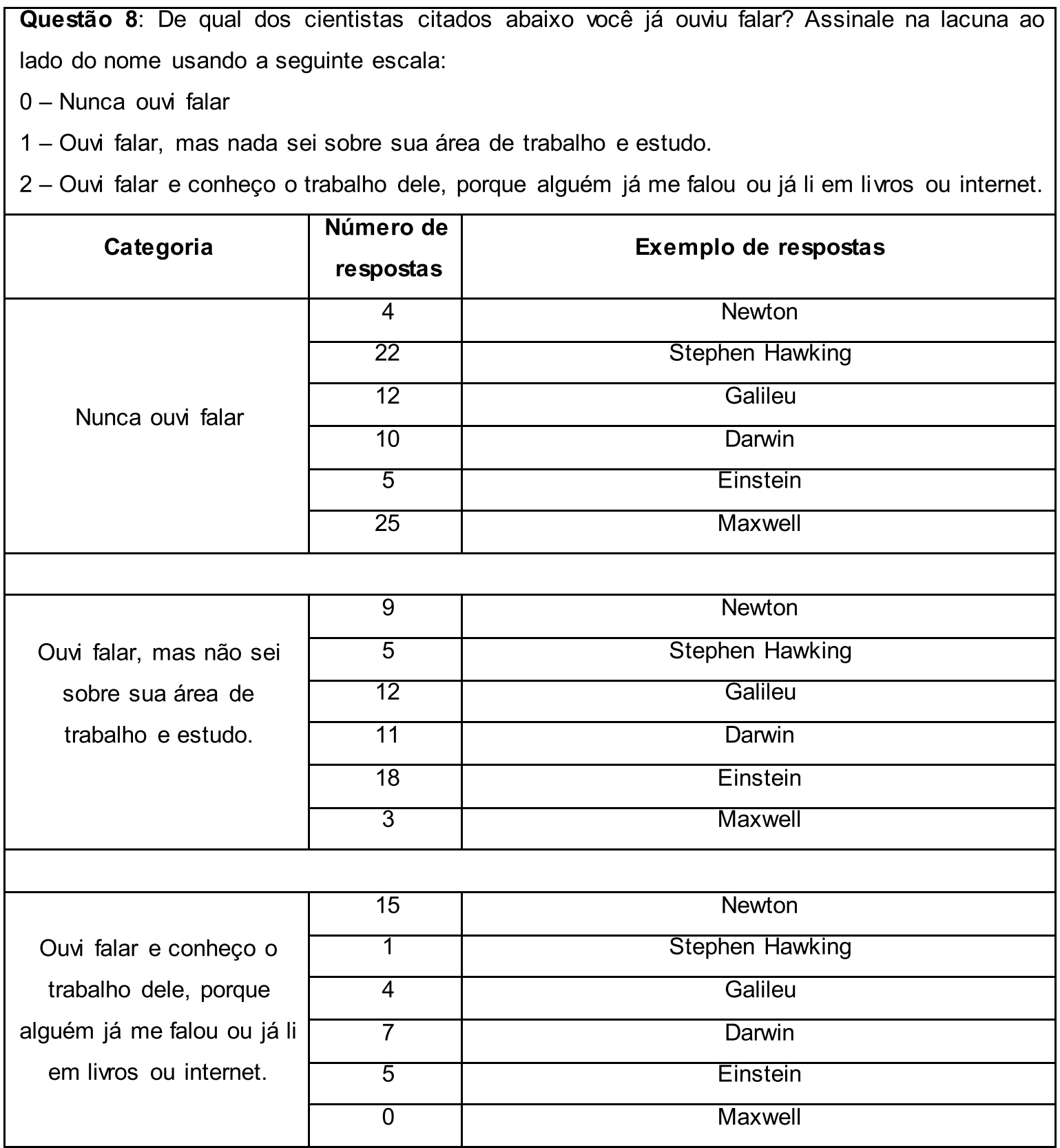

Fonte: Elaborado pela autora.

As respostas dadas pelos alunos nos permite observar o desconhecimento em relação aos físicos Stephen Hawking e Maxwell e por consequência aos seus estudos e teorias. Os nomes de Galileu e Darwin são conhecidos por mais da metade da turma, sendo que poucos alunos conhecem algum trabalho 
desenvolvido por estes cientistas. Os alunos mostraram estar mais familiarizados com Newton e suas teorias. Um número considerável de alunos, vinte e três, já ouviu falar sobre Einstein, sendo que destes, dezoito alunos, não conhece o trabalho desenvolvido por ele.

A questão 9 do questionário investigou justamente o fato dos alunos terem algum conhecimento sobre Einstein e a Teoria da Relatividade. O Quadro 11 apresenta as respostas.

Quadro 11 - Questionário de Sondagem: Questão 9

\begin{tabular}{|c|c|c|}
\hline Categoria & $\begin{array}{l}\text { Número de } \\
\text { respostas }\end{array}$ & Exemplo de respostas \\
\hline Não conhecem & 14 & $\begin{array}{l}\text { "Não conheço." (A11) } \\
\text { "Nunca ouvi falar." (A24) }\end{array}$ \\
\hline $\begin{array}{l}\text { Já ouviu falar, mas não } \\
\text { sabem do que se trata. }\end{array}$ & 7 & $\begin{array}{l}\text { "Já ouvi falar mas não sei explicar." (A19) } \\
\text { "Já vi sobre isso mas não me recordo" (A14) }\end{array}$ \\
\hline $\begin{array}{c}\text { Já ouviu falar e } \\
\text { descrevem o que sabem. }\end{array}$ & 4 & $\begin{array}{c}\text { "Sem o espaço não teríamos o tempo, sem o tempo } \\
\text { não teria o espaço, pois um precisa do outro." (A26) } \\
\text { "A teoria é que o tempo e o espaço se modifica de } \\
\text { acordo com a velocidade em que um corpo se } \\
\text { desloca." (A5) } \\
\text { "Sim, é algo relativo ao espaço e tempo." (A7) }\end{array}$ \\
\hline Não responderam & 3 & - \\
\hline
\end{tabular}

Fonte: Elaborado pela autora.

O levantamento mostrou que metade da turma (14 alunos) não conhece ou nunca ouviu falar sobre Teoria da Relatividade. Um grupo de sete alunos respondeu que já ouviu falar sobre a teoria, mas não sabe do que se trata. Apenas quatro alunos descreveram suas concepções a respeito da TR, e três alunos não responderam.

$\mathrm{Na}$ última questão do questionário de sondagem os alunos responderam se já tiveram contato com algumas equações utilizadas em Física e Matemática em locais diferentes de livros de Física e Matemática. O Quadro 12 apresenta os dados. 
Quadro 12 - Questionário de Sondagem: Questão 10

\begin{tabular}{|c|c|}
\hline $\begin{array}{l}\text { Questão 10: Qual ou quais das expressões abaixo você já viu em locais que não fossem em } \\
\text { livros de Física ou de Matemática? }\end{array}$ \\
\hline Categoria & Número de respostas \\
\hline$E=m \cdot c^{2}$ & 7 \\
\hline$v=\frac{\Delta s}{\Delta t}$ & 5 \\
\hline$F_{R}=m \cdot a$ & 3 \\
\hline$a^{2}=b^{2}+c^{2}$ & 4 \\
\hline Nenhuma & 13 \\
\hline
\end{tabular}

Fonte: Elaborado pela autora.

As respostas dadas mostram que $25 \%$ da turma (sete alunos), já viram a equação de equivalência massa-energia de Einstein. Outros cinco alunos marcaram a equação da velocidade. Quatro alunos afirmaram já terem visto a fórmula do Teorema de Pitágoras e três alunos marcaram a equação referente à Segunda Lei de Newton. Notoriamente um grupo de treze alunos afirmou nunca ter visto nenhuma das equações descritas em locais que não fossem livros de Física e Matemática. A diferença do número total de respostas e o número de alunos se deve ao fato de que os alunos marcaram mais de uma resposta na questão.

É importante destacar que a aplicação deste questionário possibilitou identificar alguns conhecimentos prévios dos alunos e a análise das respostas foi muito importante para nos orientar e direcionar nos tópicos que seriam abordados na sequência didática.

Destacamos, também, que os alunos tiveram certa dificuldade em responder ao questionário, uma vez que as questões envolviam situações que exigiam uma organização das ideias e, também, formulação de hipóteses para a elaboração das respostas. 


\subsection{AULA 2 - ESPAÇO}

$\mathrm{Na}$ segunda aula da sequência didática os alunos formaram pequenos grupos para desenvolverem as atividades. Os alunos receberam os materiais (Figura 9) e fizemos a leitura comentada do texto: Localização no Espaço Coordenadas (Apêndice C, p.117).

Figura 9 - Materiais utilizados na atividade da aula 2

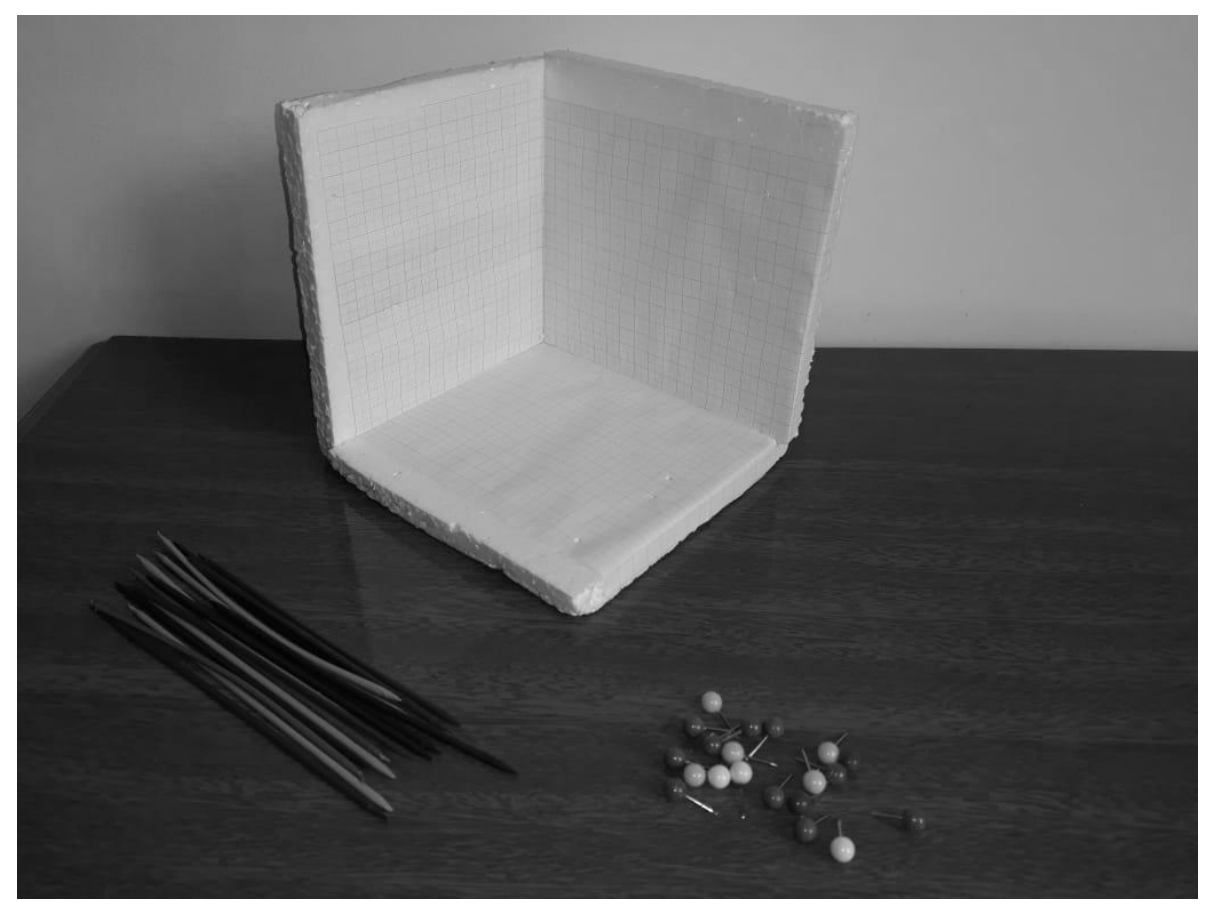

Fonte: Acervo pessoal

A proposta para essa aula era discutir com os alunos o conceito de referencial e diferenciar o conceito físico de que espaço é sinônimo de distância. Para isso, foi proposto aos alunos utilizar o aparato de isopor e papel milimetrado como um sistema de referência, para localizar alguns objetos que foram colocados em alguns pontos da sala. Os objetos eram: uma folha de cor branca colada no quadro, uma caixa de sapatos no chão da sala, uma folha de cor azul colada em uma das paredes laterais e uma caneta pendurada no teto por um fio.

Cada grupo atuou livremente na escolha da posição do seu sistema de referência e, utilizando os materiais desenvolveram a atividade, conforme vemos nas fotos abaixo. 
Figura 10 - Grupo 1 realizando a atividade

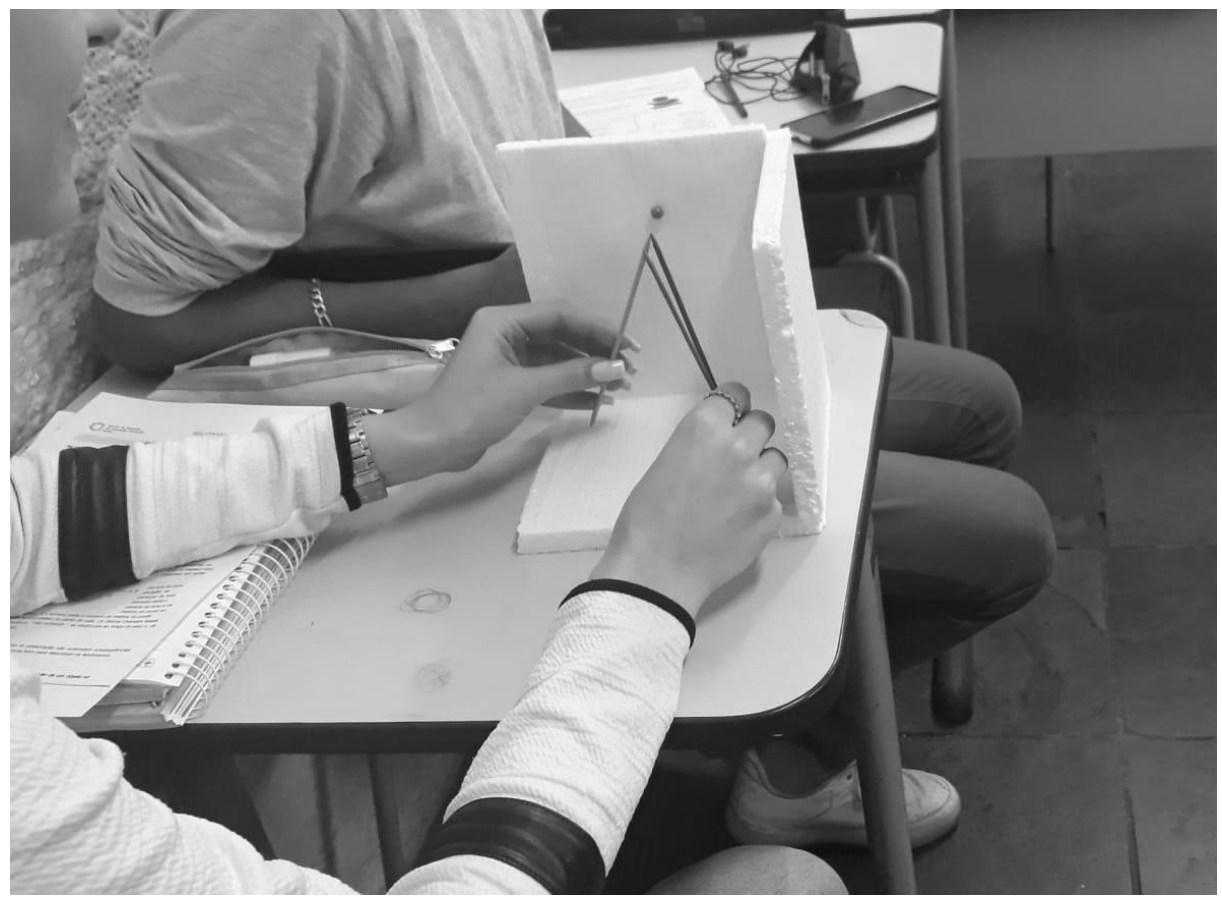

Fonte: Acervo pessoal

Figura 11 - Grupo 2 realizando a atividade

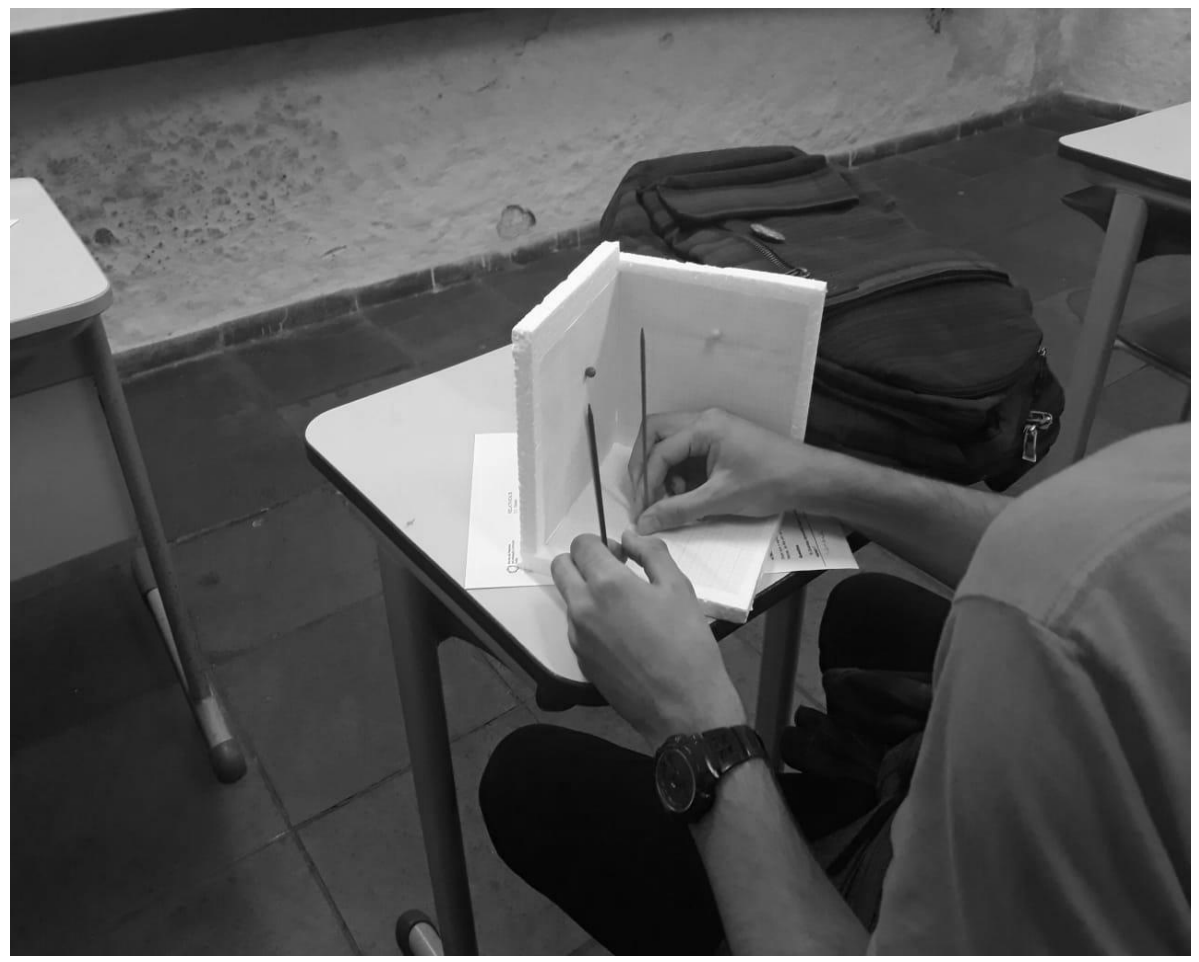

Fonte: Acervo pessoal 
Figura 12 - Grupo 3 finalizando a atividade

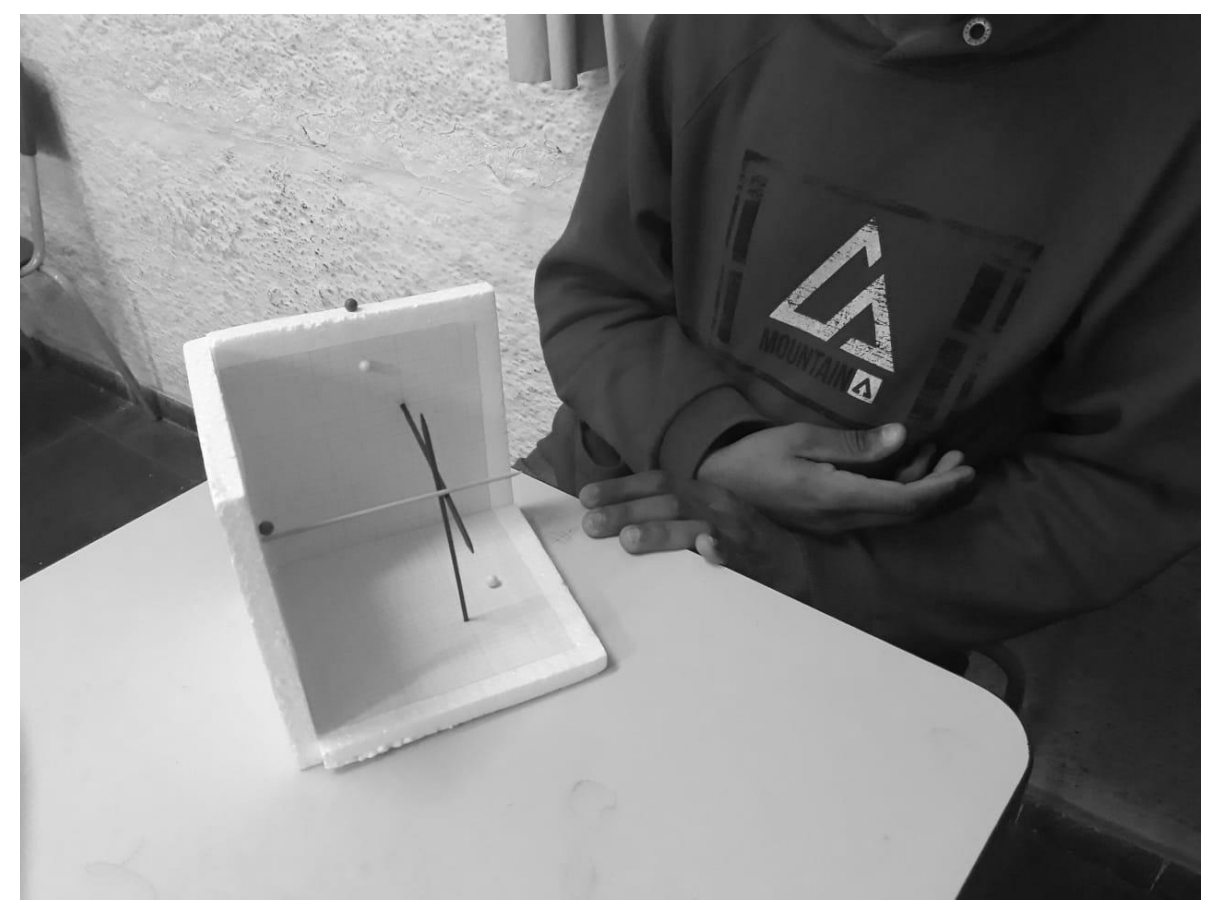

Fonte: Acervo pessoal

Figura 13: Grupo 4 finalizando a atividade

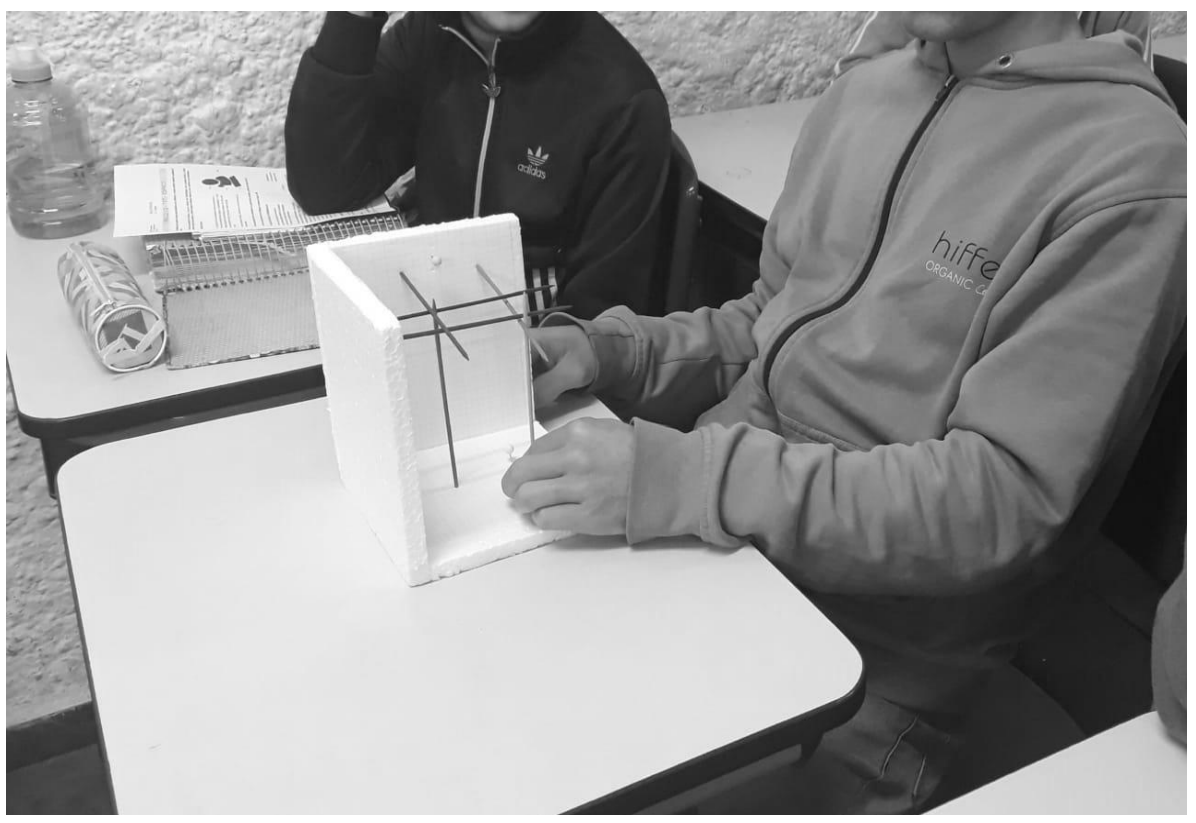

Fonte: Acervo pessoal 
Os grupos não encontraram dificuldade em representar, no aparato utilizado como referencial, a folha colada no quadro, a caixa no chão da sala e a folha em uma das paredes. Para isso, utilizaram os alfinetes coloridos.

Ao desenvolverem a atividade foi possível ver a interação entre os alunos de grupos diferentes, buscando solucionar como deveriam proceder para representar a posição da caneta pendurada por um fio. Todos os grupos apresentaram bastante dificuldade em localizar a caneta pendurada por um fio. Inicialmente, apenas um grupo conseguiu fazer, utilizando as varetas coloridas. Depois de verem como foi feita a atividade pelo grupo que concluiu primeiro, os demais também fizeram.

Figura 14 - Grupo 1 finalizando a atividade

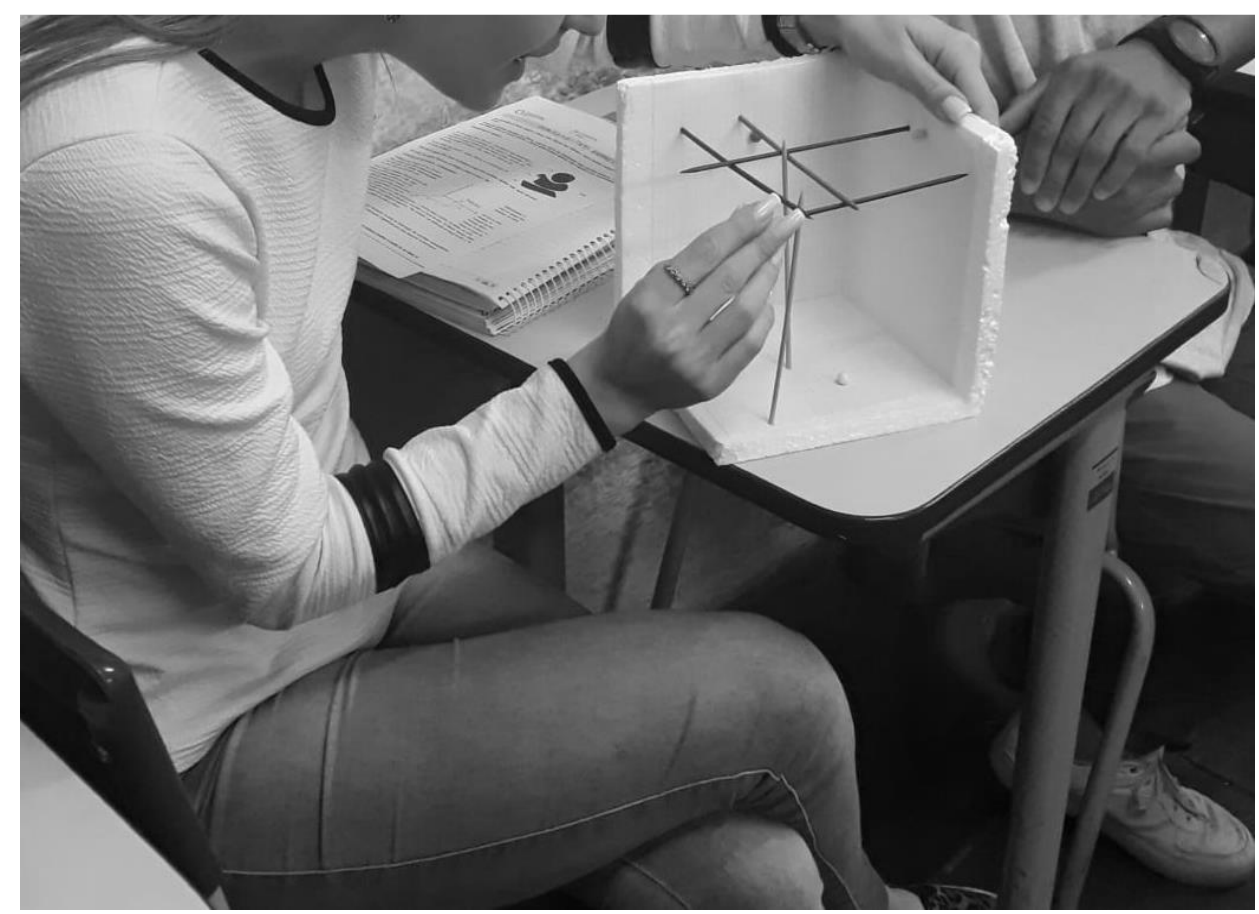

Fonte: Acervo pessoal 
Figura 15 - Grupo 2 finalizando a atividade

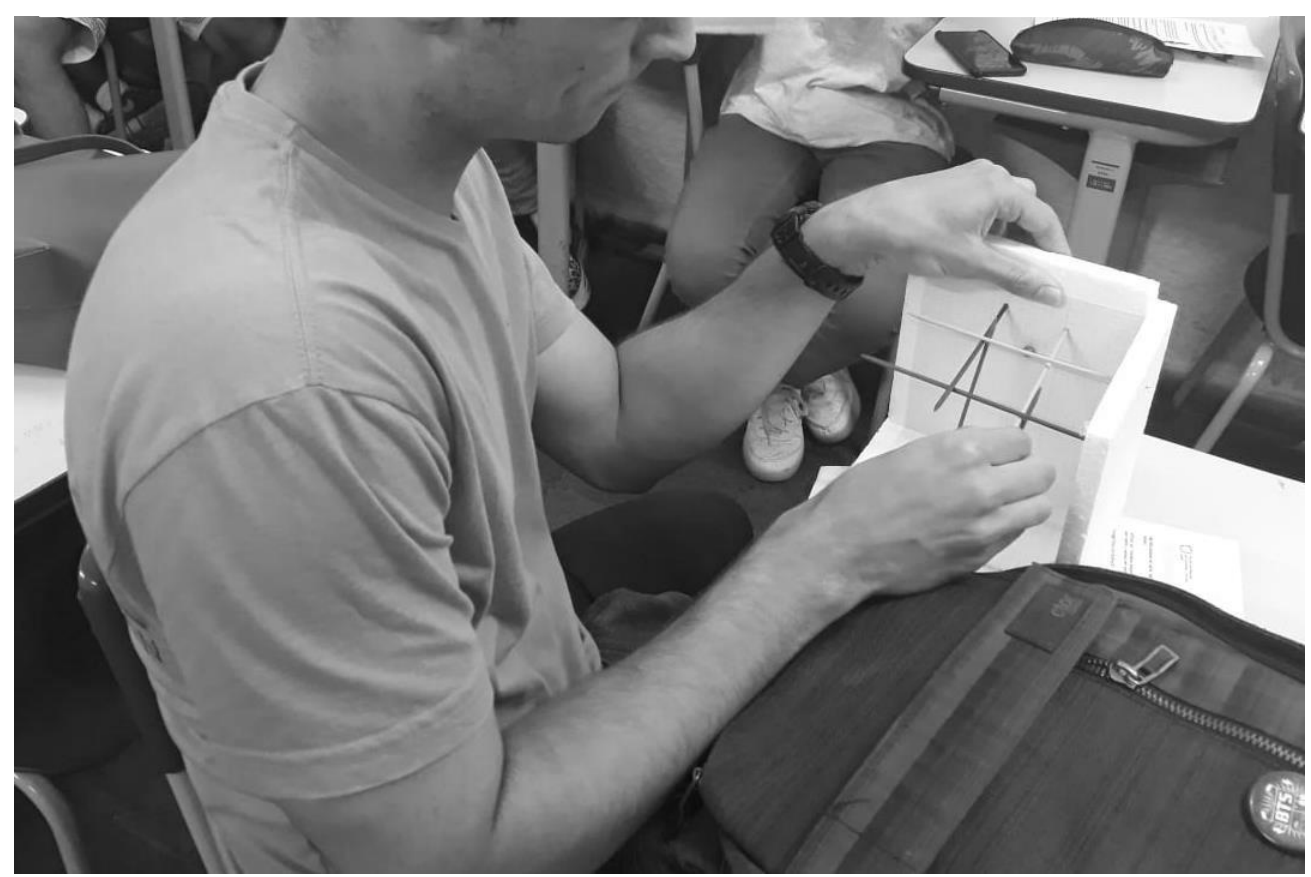

Fonte: Acervo pessoal

Após todos terem feito a atividade propusemos que cada grupo explicasse verbalmente, de forma simples, o que entendeu por referencial, espaço e distância. Todos os grupos apresentaram suas concepções e foi muito produtivo, pois, nesse momento, os alunos puderam redefinir e reconstruir tais conceitos. Aproveitamos a discussão dos temas para também estabelecer o conceito físico de evento.

Nesta aula estavam presentes vinte alunos, e todos participaram da atividade, sendo muito produtiva a aula.

Como atividade complementar cada grupo deveria responder por escrito e trazer para a próxima aula a seguinte pergunta: Quantas dimensões existem no espaço em que vivemos e como podemos localizar a posição de um objeto no espaço?

$\mathrm{Na}$ semana seguinte os grupos trouxeram as respostas. Vejamos:

Grupo 1: São três dimensões. Podemos localizar a posição de um objeto no espaço usando um sistema de referencia.

Grupo 2: Existem três dimensões, altura, largura e comprimento. Para localizar um objeto no espaço precisamos falar em que lugar o objeto está. 
Grupo 3: Três dimensões: altura, largura e profundidade. Podemos especificar a posição de qualquer local no espaço com três dimensões.

Grupo 4: São três: a altura, o comprimento e a largura. Para falar a posição de um objeto no espaço precisa saber a medida das três dimensões.

Observando as respostas apresentadas pelos grupos, nota-se que em todas aparece que o espaço possui três dimensões. Para a segunda parte da pergunta, cada grupo apresentou uma resposta diferente, mas todas apresentaram a noção de especificar um ponto no espaço.

\subsection{AULA 3 - TEMPO}

No início da terceira aula da SD foi apresentado aos alunos um trecho do vídeo da série "Além do Cosmos - Episódio: O Tempo", disponível em: https://www.youtube.com/watch?v=6munxHulhgs. O trecho apresentado tem duração de aproximadamente 8 minutos e aborda como o tempo tem sido medido ao longo da história. Após a exibição do vídeo foram feitos comentários sobre alguns tópicos, como a necessidade humana de medir o tempo e a evolução dos processos de medidas de tempo. Também discutimos sobre a definição da divisão do dia em horas e a noção de passagem do tempo. A seguir, em uma perspectiva interdisciplinar, analisamos a música "Semana que vem - Pitty" (Anexo A, p.121).

Para a realização dessa atividade os alunos novamente formaram quatro grupos. Dessa forma, foi possível que os integrantes de cada grupo conversassem sobre as noções de tempo contidas na música e discutissem o tema. Após escutarem a música, os alunos receberam uma atividade com questões relativas ao tema, que deveriam ser respondidas. As questões estão no Apêndice D (p.118).

O Quadro 13 apresenta as respostas dadas pelos grupos para a primeira questão, que tinha por objetivo ressaltar o conceito físico de tempo descrito na música. 
Quadro 13 - Questão 1: Música Semana que vem

\begin{tabular}{|c|l|}
\hline \multicolumn{2}{|l|}{$\begin{array}{l}\text { Questão 1: Como você classificaria o tempo descrito na música Semana que vem? Quais as } \\
\text { palavras usadas na música que conduzem a esse entendimento? }\end{array}$} \\
\hline Grupo 1 & $\begin{array}{l}\text { É o tempo contado no relógio, que pode ser medido. As palavas são: } \\
\text { amanhã, dias, tempo, horas, semana, mês. }\end{array}$ \\
\hline Grupo 2 & $\begin{array}{l}\text { Classificaria como o dia que ainda vai chegar, o dia de amanhã. "Nada pra } \\
\text { semana que vem, porque semana que vem pode nem chegar". }\end{array}$ \\
\hline Grupo 3 & $\begin{array}{l}\text { Classificaria o tempo como presente. No início da música fala "amanhã eu vou } \\
\text { revelar, depois eu penso", então ela fala no presente das coisas que ainda irão } \\
\text { acontecer. }\end{array}$ \\
\hline Grupo 4 & $\begin{array}{l}\text { Como um tempo que não chegou e ainda vai chegar ou pode nem chegar. As } \\
\text { acontecendo e o que pode chegar ou não. }\end{array}$ \\
\hline
\end{tabular}

Fonte: Acervo pessoal

O Grupo 1 descreveu que a música fala do tempo como sendo algo que é medido pelo relógio, ou seja, relacionava o tempo com as suas unidades de medida. Para o Grupo 2, o tempo descrito na música é algo que ainda vai acontecer, ou seja, o futuro. Já o Grupo 3 apresentou uma resposta caracterizando o tempo em que acontece a narrativa da história da música, e o Grupo 4 ressaltou que os acontecimentos em um determinado tempo futuro são incertos, podem ou não acontecer.

O Quadro 14 apresenta as respostas dadas pelos grupos para a segunda questão, fazendo os alunos refletirem sobre o tempo com os termos passado, presente e futuro.

De modo geral, os grupos expressaram a ideia de que o tempo é algo contínuo, que não para e flui seguindo um curso para frente. É interessante observar que há um consenso nas respostas ao afirmarem a ideia de que o tempo denominado presente é passageiro, a todo o momento ele já é passado. 
Quadro 14 - Questão 2: Música Semana que vem

\begin{tabular}{|c|c|}
\hline \multicolumn{2}{|c|}{$\begin{array}{l}\text { Questão 2: Leia o trecho: “... o futuro é o presente e o presente já passou...” Descreva o que } \\
\text { você pensa a respeito dessa frase. }\end{array}$} \\
\hline Grupo 1 & $\begin{array}{l}\text { O futuro é o momento que estamos agora e o mesmo acabou de passar. O } \\
\text { tempo não para! }\end{array}$ \\
\hline Grupo 2 & $\begin{array}{l}\text { Ao mesmo tempo que estamos pensando no futuro, ele está se tornando o } \\
\text { presente e ele também já se tornou passado. }\end{array}$ \\
\hline Grupo 3 & $\begin{array}{l}\text { Que o futuro não é um tempo distante, mas sim o que vivemos no presente, } \\
\text { neste momento. }\end{array}$ \\
\hline Grupo 4 & $\begin{array}{l}\text { O futuro é hoje e hoje já passou. O futuro é o momento que estamos agora e } \\
\text { agora ele já passou. }\end{array}$ \\
\hline
\end{tabular}

Fonte: Acervo pessoal

$\mathrm{Na}$ terceira pergunta da atividade os alunos deveriam descrever a opinião a respeito da importância do conceito tempo e diferenciar o tempo cronológico do tempo psicológico, assunto que foi discutido com base no vídeo assistido no início da aula. O Quadro 15 apresenta as respostas.

\section{Quadro 15 - Questão 3: Música Semana que vem}

\begin{tabular}{|c|c|}
\hline \multicolumn{2}{|c|}{$\begin{array}{l}\text { Questão 3: Descreva qual é a importância dessa entidade chamada tempo? Existem "tipos" de } \\
\text { tempos diferentes? Justifique. }\end{array}$} \\
\hline Grupo 1 & $\begin{array}{l}\text { O tempo no contexto da Física não é só uma definição de um contexto } \\
\text { cronológico, afinal, as teorias científicas evoluem assim como a vida de uma } \\
\text { pessoa. Existem tempos diferentes, como ocorrência dos eventos naturais, } \\
\text { coincidências espaciais e temporais. }\end{array}$ \\
\hline Grupo 2 & $\begin{array}{l}\text { O tempo é importante, pois com o tempo vivemos experiências novas e } \\
\text { amadurecemos. Sim, existem várias classificações de tempo, o que se pode } \\
\text { contar as horas, dias, semanas etc. E o tempo que existe dentro da nossa } \\
\text { cabeça, que é formado a partir de cada situação que presenciamos. }\end{array}$ \\
\hline Grupo 3 & $\begin{array}{l}\text { E de grande importância o tempo, ele move todas as coisas. Existem dois tipos } \\
\text { de tempos o psicológico e o de horas e minutos, esse é igual para todos } \\
\text { mostrando a passagem de tempo, já o psicológico é o tempo dentro da nossa } \\
\text { mente. }\end{array}$ \\
\hline Grupo 4 & $\begin{array}{l}\text { O tempo é muito importante em nossas vidas. O tempo é uma grandeza física } \\
\text { que permite medir a duração ou a separação das coisas. Existem vários tipos } \\
\text { de tempo como, por exemplo, tempo de uma música, tempo clima da estação, } \\
\text { tempo do relógio, tempo histórico e também o tempo dentro da nossa mente. }\end{array}$ \\
\hline
\end{tabular}




\subsection{AULA 4 - POSTULADOS DA TEORIA DA RELATIVIDADE RESTRITA}

Com o intuito de apresentar a Teoria da Relatividade e seus postulados de modo informal, foi apresentado aos alunos um vídeo, disponível em https://www.youtube.com/watch?v=nf32ejhzTNQ. Apresentando uma linguagem de fácil entendimento, inicialmente, no vídeo é abordado o conceito físico de repouso e movimento; em seguida, o conceito de referencial é definido. Após é feita uma descrição da composição de velocidades para objetos, e se descrevem características importantes da luz, como o valor finito de sua velocidade e o fato de que essa velocidade independe do referencial da fonte que emite a luz. A seguir, é discutido o fenômeno da Dilatação do Tempo e da Contração do Espaço, sendo também descrito o comportamento da partícula múon. Por fim, a equivalência massa-energia é abordada, e o vídeo termina com uma revisão dos tópicos vistos.

Buscando promover uma melhor assimilação dos conteúdos, inicialmente os alunos assistiram ao vídeo completo, e na sequência, retomamos parte por parte do vídeo. Nesse momento, foi possível enfatizar novamente os conceitos e esclarecer as dúvidas.

Os alunos fizeram anotações em seus cadernos sobre os conceitos e os postulados da TRR. Nessa aula os alunos não realizaram atividades escritas.

\subsection{AULA 5 - DILATAÇÃO DO TEMPO E CONTRAÇÃO DO ESPAÇO}

Iniciamos a aula com uma revisão dos conceitos sobre a Teoria da Relatividade. Os postulados da TRR foram novamente enunciados e, dando prosseguimento, foram discutidos os efeitos de contração do espaço e da dilatação do tempo; a seguir, foram apresentadas suas respectivas equações e a professora resolveu no quadro exemplos envolvendo situações relativísticas. Alguns alunos demonstraram muita dificuldade na resolução matemática dos exercícios.

Visando uma interdisciplinaridade, a dilatação temporal foi exemplificada por uma abordagem ao funcionamento do GPS (Sistema de Posicionamento Global). Para isso, os alunos receberam um texto de divulgação científica e um 
infográfico sobre o funcionamento do GPS. O texto encontra-se no Anexo B (p.122) e o infográfico no Anexo C (p.124).

A professora fez a leitura do texto com os alunos, destacando que, a localização por meio do GPS envolve duas teorias de Einstein, primeiro, pelo fato dos agentes envolvidos (satélite emissor e receptor na Terra) apresentarem velocidade relativa grande o suficiente para que os efeitos relativísticos sejam relevantes: dessa forma, o tempo marcado pelos relógios deve ser corrigido, levando-se em conta a Teoria da Relatividade Restrita. Segundo, como os satélites são colocados em órbita da Terra, seus relógios sofrem a ação do campo gravitacional do planeta e, para fazer a devida correção, é necessária uma análise de acordo com a Teoria da Relatividade Geral. Enfatizamos que nossa sequência didática não contemplará a Teoria da Relatividade Geral; desse modo, nossa análise será limitada à abordagem dos efeitos da dilatação temporal compreendidos dentro da TRR.

Após a leitura do texto e do infográfico, os alunos puderam expressar suas impressões sobre o tema. Duas manifestações se destacaram. $\mathrm{O}$ aluno $\mathrm{A} 1$ disse que estava surpreso ao ver que algo "descoberto" por Einstein, no caso a dilatação temporal, era possível de ser aprendido e entendido na escola, o que contraria a ideia de que a ciência feita pelos cientistas não é acessível ao público em geral. Já o aluno A2 ao comentar sobre a aplicação da TRR para o funcionamento do GPS disse: "achava que essas coisas que a gente aprende aqui na escola era só praqui mesmo, não usava lá fora".

\subsection{AULA 6 - RELAÇÃO DE EQUIVALÊNCIA MASSA-ENERGIA}

Nessa aula abordamos a relação de Equivalência Massa-Energia analisando a equação $E=m \cdot c^{2}$.

No início da aula a equação foi escrita no quadro e a professora perguntou quem já tinha visto tal equação. Apenas dois alunos responderam que já tinham visto. Também foi perguntado qual era o significado de cada letra, e alguns alunos responderam corretamente que $m$ representava massa, e $c$ a velocidade da luz. Após esse momento os alunos receberam um material impresso que está disponivel em: http://atp.usp.br:9080/rid=1LRSXM3P6-29LTCH8XX/REA.4.4.1.pdf. Os textos encontram-se no (Anexo D, p.125) e no (Anexo E, 
p.126). A seguir, a professora realizou a leitura dos textos fazendo uma explanação do tema, juntamente com a realização dos cálculos. Por meio dos dados fornecidos pelo texto, os alunos conheceram o poder destruidor da bomba atômica e, como atividade, resolveram alguns problemas propostos.

Alguns alunos demostraram surpresa ao ler sobre a bomba atômica. Questionados se já conheciam algo sobre o conteúdo trabalho na aula, todos os alunos responderam que era a primeira vez que estavam recebendo essas informações. É importante salientar que de acordo com o perfil da turma (EJA), para a grande maioria desses alunos, esse será talvez o único contato que eles terão com esse conteúdo.

\subsection{AULA 7 - AVALIAÇÃO}

Na última aula da sequência didática foi aplicado um questionário avaliativo (Apêndice E, p.119), para verificação da aprendizagem dos conteúdos apresentados e estudados.

Para realizarem a avaliação, os alunos se dividiram em quatro grupos. Optamos por fazer a avaliação desse modo, pois observamos que as atividades realizadas em grupos proporcionaram momentos enriquecedores de discussão dos conteúdos, além de promoverem um ambiente mais favorável a aprendizagem. Cada aluno recebeu sua folha com o questionário, mas, para respondê-lo, puderam trocar opiniões e discutir ideias. Foi possível observar a argumentação dos alunos em busca das respostas das questões. $O$ fato de defenderem uma resposta como a correta e apresentarem argumentos na explicação para o colega que não entendeu, já demonstra o conhecimento que foi absorvido pelo aluno. Todos os alunos presentes responderam satisfatoriamente as perguntas da avaliação.

Ressaltamos que, para essa avaliação, o que nos importa são elementos que evidenciem a apreensão dos conceitos por parte dos alunos.

A avaliação foi aplicada a 19 alunos que estavam presentes na aula. O questionário avaliativo apresentou questões de caráter qualitativo e quantitativo, englobando os conteúdos estudados nas aulas da sequência didática.

No Quadro 16 categorizamos a primeira questão do questionário. 
Quadro 16 - Questionário avaliativo: Questão 1

Questão 1: Identifique a proposição correta

A) A Terra é um corpo em repouso.

B) Uma pessoa sentada num banco de jardim está em repouso.

C) Se um corpo estiver em repouso em relação a um dado referencial, então estará em movimento em relação a qualquer outro referencial.

D) Para afirmar que um corpo está em repouso ou em movimento não dependemos do referencial adotado.

E) Um corpo pode estar em repouso em relação a um referencial e em movimento em relação a outro.

\begin{tabular}{|l|c|}
\hline Responderam a questão de forma adequada. & 13 alunos \\
\hline Não responderam a questão de forma adequada. & 6 alunos \\
\hline Não responderam a questão. & 0 alunos \\
\hline
\end{tabular}

Fonte: Acervo pessoal

$\mathrm{Na}$ questão 1 os alunos deveriam utilizar os conceitos de referencial, repouso e movimento para analisar as situações descritas. A questão apresentou um índice de $68 \%$ de acertos, mostrando que para os 13 alunos tais conceitos foram assimilados.

$\mathrm{Na}$ segunda questão os alunos deveriam escrever duas características da velocidade da luz. Era esperado que os alunos utilizassem os conceitos estudados na TRR, em particular, o Segundo Postulado e descrevessem sobre o valor da velocidade da luz no vácuo, sobre a invariância deste valor, ou também sobre ele ser um limite universal e intransponível. O quadro 17 apresenta a categorização das respostas.

Quadro 17 - Questionário avaliativo: Questão 2

\begin{tabular}{|c|c|}
\hline Responderam a questão de forma adequada. & 15 alunos \\
\hline Não responderam a questão de forma adequada. & 4 alunos \\
\hline Não responderam a questão. & 0 aluno \\
\hline
\end{tabular}

Fonte: Acervo pessoal 
Todos os alunos responderam a essa questão, descrevendo em suas respostas as características da velocidade da luz. Quatro alunos apontaram só uma característica em suas respostas, escreveram apenas o valor da velocidade da luz no vácuo. Segue abaixo alguns exemplos de respostas dadas.

"A velocidade da luz possui um valor máximo." (A5)

"Nada é mais rápido que a luz. Sua velocidade é de 300000 km/s." (A13)

"Nenhum objeto pode ter velocidade maior que a velocidade da luz." (A7)

A questão 3 possui duas partes. Na letra a, os alunos deveriam descrever que os fenômenos relativísticos de dilatação temporal e contração do comprimento só são observados quando o objeto em análise encontra-se a uma velocidade próxima à da luz. E na letra b, que esses fenômenos não são observados em nosso cotidiano devido ao fato de que vivemos em um mundo com velocidades muito baixas comparadas com a da luz. O Quadro 18 sintetiza as respostas.

Quadro 18 - Questionário avaliativo: Questão 3

Questão 3: Durante nossas aulas estudamos sobre os fenômenos relativísticos da dilatação temporal e da contração do comprimento. Em relação a isso, responda:

a) O que é necessário para que esses fenômenos aconteçam?

b) Por que tais fenômenos não são observados em nosso cotidiano?

\begin{tabular}{|l|c|}
\hline Responderam a questão de forma adequada. & 10 alunos \\
\hline Não responderam a questão de forma adequada. & 8 alunos \\
\hline Não responderam a questão. & 1 aluno \\
\hline
\end{tabular}

Fonte: Acervo pessoal

Os alunos tiveram um pouco de dificuldade em responder essa questão. A dificuldade apresentada foi a de relacionar a necessidade de o móvel estar com velocidade próxima à da luz para que os fenômenos ocorram. Oito alunos deixaram a questão incompleta, respondendo a apenas uma das letras. A seguir alguns exemplos de respostas. 
"A gente não vê esses fenômenos porque ninguém consegue viajar na velocidade

da luz" (A2)

"Porque o ser humano não consegue alcançar a velocidade da luz.” (A11)

"Para que estes fenômenos aconteçam é preciso atingir a velocidade da luz. E por isso não vemos isso acontecendo, porque a velocidade da luz é muito grande e ninguém conseguiu construir uma nave para atingir essa velocidade." (A10)

$\mathrm{Na}$ quarta questão os alunos responderam sobre o conceito de contração espacial. O Quadro 18 apresenta as respostas.

Quadro 18 - Questionário avaliativo: Questão 4 (Continua)

Questão 4: (UFRN) Bastante envolvida com seus estudos para a prova do vestibular, Silvia selecionou o seguinte texto sobre Teoria da Relatividade para mostrar a sua colega Tereza:

À luz da Teoria da Relatividade Especial, as medidas de comprimento, massa e tempo não são absolutas quando realizadas por observadores em referenciais inerciais diferentes. Conceitos inovadores como massa relativística, contração de Lorentz e dilatação temporal desafiam o senso comum. Um resultado dessa teoria e que as dimensões de um objeto são máximas quando medidas em repouso em relação ao observador.

Quando o objeto se move com velocidade $V$, em relação ao observador, o resultado da medida de sua dimensão paralela à direção do movimento e menor do que o valor obtido quando em repouso. As suas dimensões perpendiculares à direção do movimento, no entanto, não são afetadas.

Depois de ler esse texto para Tereza, Silvia pegou um cubo de lado $L_{\circ}$ que estava sobre a mesa e fez a seguinte questão para ela:

Como seria a forma desse cubo se ele estivesse se movendo, com velocidade relativística constante, conforme direção indicada na figura abaixo?

A resposta correta de Tereza a essa pergunta foi:

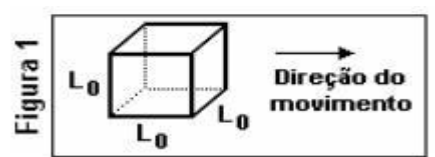

a)

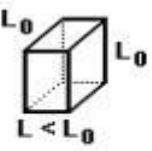

b)

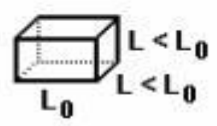

c)

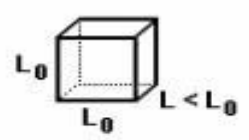

d)

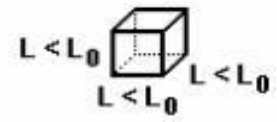

\begin{tabular}{|l|c|}
\hline Responderam a questão de forma adequada. & 12 alunos \\
\hline Não responderam a questão de forma adequada. & 5 alunos \\
\hline Não responderam a questão. & 2 alunos \\
\hline
\end{tabular}

Fonte: Acervo pessoal 
Para marcar a alternativa correta era necessário relacionar o conceito de que a contração espacial só acontece na direção do movimento, dessa forma, analisando as figuras deveriam marcar a letra a. Cinco alunos marcaram a alternativa $d$, onde está representado o cubo com todas suas dimensões reduzidas, o que reflete que para tais alunos a contração espacial faz o objeto encolher em todas as suas dimensões. Doze alunos, $63 \%$ da turma, marcaram corretamente a alternativa a, e 2 alunos não marcaram nenhuma das opções.

A questão 5 do questionário avaliativo abordou o fenômeno da dilatação temporal usando como exemplo o Paradoxo dos Gêmeos. Exercícios semelhantes foram resolvidos nas aulas. No Quadro 19 temos a categorização das respostas.

Quadro 19 - Questionário avaliativo: Questão 5

Questão 5: Um exemplo conhecido da aplicação do fenômeno relativístico da dilatação temporal e dos Postulados da Teoria da Relatividade Restrita de Einstein é o "paradoxo dos gêmeos".

Imagine que gêmeos idênticos são separados ainda crianças, um deles permanece na Terra enquanto o outro é colocado em uma nave espacial para viajar a uma velocidade de $80 \%$ da velocidade da luz no vácuo $(0,8 \mathrm{c})$. Depois de passados 70 anos para o gêmeo que ficou na Terra o gêmeo astronauta volta e algo curioso é observado, o gêmeo que ficou aqui na Terra teria a aparência de estar mais velho que seu irmão.

De acordo com as informações acima, qual seria a idade do irmão gêmeo astronauta?
A) 35 anos
B) 42 anos
C) 60 anos
D) 70 anos
E) 85 anos

\begin{tabular}{|l|c|}
\hline Responderam a questão de forma adequada. & 11 alunos \\
\hline Não responderam a questão de forma adequada. & 8 alunos \\
\hline Não responderam a questão. & 0 aluno \\
\hline
\end{tabular}

Fonte: Acervo pessoal

Para a resolução da questão, os alunos deveriam utilizar a equação para a dilatação do tempo (Transformação de Lorentz) e aplicar os dados fornecidos na questão e encontrar o valor de 42 anos. Uma das dificuldades apresentadas pelos alunos foi identificar que a idade do gêmeo astronauta se tratava do chamado tempo próprio. Alguns alunos tiveram muita dificuldade com a resolução matemática da questão. Dos oito alunos que erraram a questão, quatro marcaram a alternativa $C$ e os outros quatro marcaram a alternativa $D$.

$\mathrm{Na}$ sexta questão do questionário o conteúdo cobrado foi a relação de equivalência massa-energia. A seguir, a descrição no Quadro 20. 
Quadro 20 - Questionário avaliativo: Questão 6

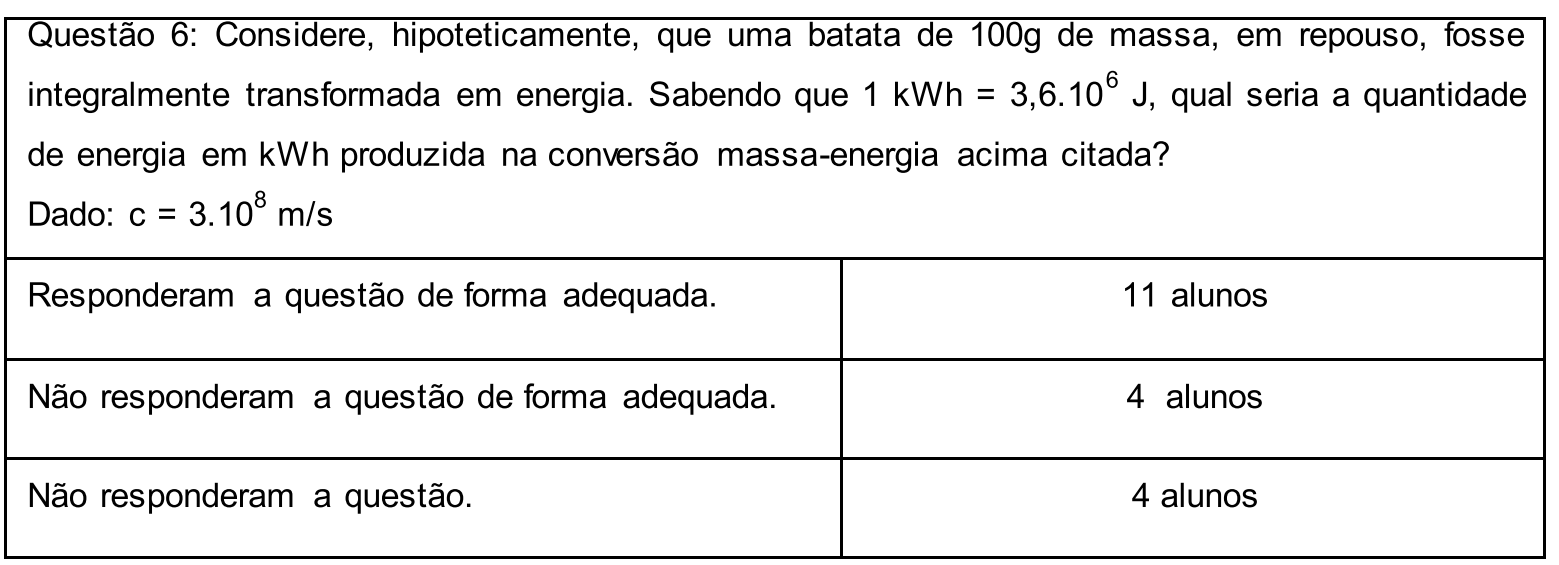

Fonte: Acervo pessoal

Nessa questão os alunos deveriam utilizar a equação $E=m c^{2}$ para encontrar o valor de energia gerado na conversão da massa da batata. E para finalizar deveriam converter o valor de energia encontrado em Joules para kWh. Quatro alunos não responderam a essa questão. Um grupo de onze alunos resolveu corretamente a questão, realizando as devidas conversões de unidades e efetuando os cálculos matemáticos corretamente. Quatro alunos não responderam a questão de forma adequada, pois utilizaram apenas o valor de c e não $c^{2}$, e também não apresentaram a conversão de energia em Joules para kWh.

$\mathrm{Na}$ última pergunta da avaliação foi solicitado que alunos fizessem comentários ou sugestões sobre as aulas de Relatividade Restrita. Seguem abaixo algumas das respostas formuladas pelos alunos.

"Acredito que foi importante na minha formação como aluno, pois é interessante saber sobre coisas novas. Seria bom aprofundar mais sobre o assunto". (A14)

"O assunto Relatividade é importante, é uma matéria diferente, tem a ver com o que aparece às vezes em filmes." (A9)

"Eu acho que a gente só não aprendeu mais sobre Relatividade porque a parte de matemática atrapalha, e também porque a gente tem que ficar imaginando certas coisas pra tentar entender" (A3) 
"Eu achei muito bom, mas tenho muita dificuldade em entender física. Mas essa matéria foi interessante, porque estudamos ela um pouco diferente, às vezes nem parecia aula de Física." (A17)

"Essas aulas de Física foram boas. Foi bom estudar coisas novas que tem a ver com tecnologia." (A1)

De acordo com os relatos dos alunos, acreditamos que a apresentação dos conceitos da Teoria da Relatividade Restrita nas aulas de Física foi muito produtiva.

Portanto, buscamos no decorrer da aplicação da sequência didática avaliar qualitativamente os processos realizados, quando assim fora permitido. Dessa forma, avaliamos uma grande evolução conceitual, expressa pelos escritos dos alunos. Durante a aplicação, observamos o interesse e o envolvimento de um número considerável de alunos da turma, o que evidencia que as diferentes estratégias de ensino adotadas podem tornar as aulas mais interativas e interessantes. Desse modo, por todos os fatores acima citados e mediante os relatos colhidos ao longo das atividades desenvolvidas, há evidências de uma aprendizagem significativa. 


\section{CONSIDERAÇÕES FINAIS}

Nesta dissertação, elaboramos e aplicamos uma Sequência Didática (SD) abordando tópicos da Teoria da Relatividade Restrita (TRR) de Albert Einstein. A análise dos dados coletados permitiu inferir características da percepção e aprendizagem de estudantes de uma turma do $3^{\circ}$ ano da Educação de Jovens e Adultos (EJA).

Nossa pretensão com essa SD foi apresentar os conceitos básicos da Relatividade Restrita de forma mais acessível e compreensível para os estudantes, visando facilitar a aprendizagem da TRR.

Consideramos importante a inserção de temas relacionados à Física Moderna e Contemporânea em nossas salas de aula, fato que se justifica, em essência, pelo fato de vivermos em uma sociedade com acelerado desenvolvimento científico e tecnológico. Pode ser observado que os alunos de Ensino Médio se interessam, de forma cada vez mais acentuada, por temas da Física relacionados a avanços científicos. Em geral, tais temas envolvem a Mecânica Quântica e a Teoria da Relatividade. No escopo desse cenário, nos parece extremamente necessário a escola buscar formar cidadãos cada vez mais engajados com o processo de alfabetização científica. Para tanto, consideramos que a escola deve oferecer condições, ferramentas cognitivas e conhecimentos que auxiliem os alunos a compreenderem melhor a sua realidade e interpretarem de forma mais racional o mundo à sua volta.

Pudemos perceber o desafio da aplicação da sequência didática a alunos da EJA. Tratava-se de uma turma muito eclética, com alunos de faixa etária entre 18 e 41 anos, com diferentes percepções e concepções de mundo.

Outro fato que buscamos explorar foi a diversificação de interesse na aquisição de novos conhecimentos. Assim, inicialmente, aplicamos um questionário, com a intenção de fazer um levantamento dos conhecimentos prévios dos alunos acerca de conceitos relacionados com a Teoria da Relatividade Restrita. Percebemos logo a importância desse procedimento pedagógico, visto que, por meio dele foi possível nortear nossas aulas. As respostas dos estudantes evidenciaram não só suas concepções prévias, mas também suas dificuldades de 
aprendizagem, o não conhecimento de importantes conceitos científicos, e ainda manifestações de concepções equivocadas.

Dessa forma, levando em consideração as concepções prévias da turma, conduzimos as aulas da SD tentando compatibilizar anseios e possibilidades, de modo a se obter um quadro de melhor relação entre ensino e aprendizagem.

No desenvolvimento da SD, foram abordados conceitos de referencial, de espaço e de tempo, bem como os conceitos básicos da TRR, com seus postulados e consequências, com ênfase para a dilatação temporal e a contração espacial, e também a relação de equivalência massa-energia. Em cada aula procuramos adotar um recurso didático diferente. Assim, foram utilizados textos, músicas, vídeos, atividades práticas e produção textual.

Observamos um bom retorno da aplicação das estratégias utilizadas, parecendo essas terem sido muito produtivas, com os estudantes demonstrando razoável envolvimento nas atividades. Destacamos e constatamos que aulas ministradas com metodologias distintas do ensino tradicional têm grande potencial de oferecer aos alunos oportunidades de desenvolvimento de habilidades e competências, inclusive em outras disciplinas e outras áreas. Certamente, a utilização da Teoria da Aprendizagem Significativa, de David Ausubel, se constituiu numa âncora confiável, e de qualidade, para o desenvolvimento de nossa investigação.

Consideramos que as atividades desenvolvidas pelos alunos durante as aulas da sequência didática proporcionaram a aquisição não somente dos conceitos da Teoria da Relatividade Restrita, mas também ajudaram a promover o amadurecimento acadêmico, a articulação de ideias, a interpretação de textos, o desenvolvimento da leitura e da escrita e um perceptível aumento na capacidade de abstração. Tais habilidades e competências são fundamentais para a formação e o desenvolvimento de um cidadão verdadeiramente crítico.

Nesse sentido, podemos assegurar que as atividades desenvolvidas proporcionaram aos alunos momentos de aprendizagem que extrapolaram o ambiente da sala de aula, com reflexos em suas casas, em seus trabalhos, na família, na sua comunidade como um todo.

Assim, diante das razões apresentadas, podemos com bastante confiança indicar um progresso significativo por parte dos alunos, que conseguiram desenvolver uma percepção dos conceitos apresentados, de forma mais lúcida e 
segura. Face aos resultados extraídos da análise dos dados, consideramos que a sequência didática apresentada nesta dissertação parece mostrar um potencial pedagógico com razoável chance de sucesso, em episódios de aplicação a alunos do Ensino Médio e EJA.

Com certo grau de confiabilidade, com base no que observamos e vivemos, muito em função de um perceptível aumento de nossa maturidade acadêmica, não só como pesquisadora, mas também como docente, podemos nos arriscar a sugerir que a SD em pauta pode conduzir a uma aprendizagem significativa do tema em questão. Obviamente, recomendamos a colegas e a quem mais interessar, sua aplicação, de modo a que mais análises e percepções possam surgir, enriquecendo assim o processo pedagógico envolvido. 


\section{REFERÊNCIAS}

ARRUDA, S. M.; VILLANI, A. Mudança conceitual no ensino de ciências. Caderno Catarinense de Ensino de Física, Florianópolis, v. 11, n. 2, p.88 - 99, ago. 1994.

BARDIN, L. Análise de conteúdo. São Paulo: Edições 70, 2011.

BOGDAN R. C.; BIKLEN. S. K. Investigação Qualitativa em Educação. Traduzido por: Maria José Alvarez; Sara Bahia dos Santos e Telmo Mourinho Baptista. Ed. Porto Editora. 1994.

BRASIL. Ministério da Educação, Secretaria de Educação Média e Tecnológica. Parâmetros Curriculares Nacionais: Ensino Médio. Brasília: MEC, 1999.

BRASIL. Secretaria de Educação Básica. Diretoria de Apoio à Gestão Educacional. Pacto nacional pela alfabetização na idade certa: alfabetização em foco: projetos didáticos e sequências didáticas em diálogo com os diferentes componentes curriculares: ano 03, unidade 06 / Ministério da Educação, Secretaria de Educação Básica, Diretoria de Apoio à Gestão Educacional. Brasilia: MEC, SEB, 2012. 47 p.

CRESWELL, J. W. Projetos de pesquisa: métodos qualitativo, quantitativo e misto. 2. ed. Porto Alegre: Bookman, 2007.

GHEDIN, Evandro. Teorias Psicopedagógicas do Ensino Aprendizagem. Boa Vista: UERR $2012 . \quad$ Editora, Disponível em: http://nelsonreyes.com.br/Teorias Psicopedagogicas Evandro Ghedin.pdf.

Acesso em 07.out.2019.

HEWIT, P. G. Física conceitual. 12. ed. Porto Alegre: Bookman, 2015.

KOBASHIGAWA, A.H.; ATHAYDE, B.A.C.; MATOS, K.F. de OLNEIRA; CAMELO, M.H.; FALCONI, S. Estação ciência: formação de educadores para o ensino de ciências nas séries iniciais do ensino fundamental. IV Seminário Nacional ABC na Educação Científica. São Paulo, 2008. p.212-217.

LÜDKE, M; ANDRÉ, M. E. D. A. Pesquisa em educação: abordagens qualitativas, $1^{\text {a }}$ reimpressão, São Paulo: Editora Pedagógica e Universitária, 1986.

MARTINS, R.A. A Física no final do século XIX: modelos em crise. Física Moderna: Mito e Ciência. SBPC, 2001. Disponível em: https://www.comciencia.br/dossies-1-72/reportagens/fisica/fisica05.htm. Acesso em 02.dez.2020.

MOREIRA, M. A. O que é afinal aprendizagem significativa? Revista cultural La Laguna Espanha, 2012. Disponível em: http://moreira.if.ufrgs.br/oqueeafinal.pdf. Acesso em 04.set.2020. 
MOREIRA, M. A., CABALLERO, M. C. e RODRIGUEZ, M. L. (Orgs.). Aprendizagem significativa: um conceito subjacente. In: Actas del Encuentro Internacional sobre el Aprendizaje Significativo. Burgos, España, p.19-44, 1997.

MOREIRA, M.A. e MASINI, E.A.F. Aprendizagem significativa: a teoria de David Ausubel. São Paulo: Moraes, 1982.

MOREIRA, Marco Antônio. A teoria da aprendizagem significativa de Ausubel. Monografia $n^{\circ} 10$ da série Enfoques Teóricos. Porto Alegre. Instituto de Física da UFRGS. Originalmente divulgada, em 1980, na série "Melhoria do Ensino", do Programa de Apoio ao Desenvolvimento do Ensino Superior (PADES)/ UFRGS, N" 15. Publicada, em 1985, no livro "Ensino e aprendizagem: enfoques teóricos", São Paulo, Editora Moraes, p. 61-73. Revisada em 1995. Disponível em: https://edisciplinas.usp.br/pluginfile.php/3369246/mod resource/content/1/Capitulo $\begin{array}{ll}\% & 2010 \% 20\end{array}$ \%20A\%20teoria $\% 20$ da $\% 20$ aprendizagem $\% 20$ significativa $\% 20$ de $\% 20$ Ausubel $\% 20$ $\% 20$ Teorias $\% 20$ de\%20Aprendizagem\%20-\%20Moreira\%2C\%20M.\%20A.pdf. Acesso em 12.ago.2020.

NUSSENZVEIG, H. M. Curso de Física Básica. 4 ed, v. 4. São Paulo: Ed. Edgard Blücher, 2002.

OLIVEIRA, Maria Marly. Sequência didática interativa no processo de formação de professores. Petrópolis, RJ: Vozes, 2013.

OSTERMANN, F. A epistemologia de Kuhn. Cad. Cat. Ens. Fis., v.13,n3: p.184196, dez.1996.

. Um texto para professores do ensino médio sobre partículas elementares. Revista Brasileira de Ensino de Física, v. 21, n. 3, p.415-436, set. 1999.

OSTERMANN, F.; RICCI T. F. Relatividade restrita no ensino médio: os conceitos de massa relativística e de equivalência massa-energia em livros didáticos de física. Cad. Bras. Ens. Fís., v. 21, n. 1: p.83-102, abr. 2004.

OSTERMANN, Fernanda; CAVALCANTI, Cláudio José de Holanda. Teorias de aprendizagem. Porto Alegre: Evangraf, UFRGS, Universidade Aberta do Brasil, 2011. 58 p.

PEDUZZI, L. O. Q. A relatividade einsteiniana: uma abordagem conceitual e epistemológica. Publicação interna. Florianópolis: Departamento de Física, Universidade Federal de Santa Catarina, 2009.

Do átomo grego ao átomo de Bohr. Publicação interna. Florianópolis: Departamento de Física, Universidade Federal de Santa Catarina, 2005. 
PIATTELLA, O. F. O artigo fundador da teoria da relatividade restrita: Sobre a eletrodinâmica dos corpos em movimento. Cadernos de Astronomia, Vitória, v. 1, n. 1 , p.157-176, 2020. Disponível em: https://periodicos.ufes.br/astronomia/article/view/31681. Acesso em: 13.nov. 2020.

PORTO, C.M. e PORTO, M.B.D.S.M. Uma visão do espaço na mecânica newtoniana e na teoria da relatividade de Einstein. Revista Brasileira de Ensino de Física, v. 30, n. 1, 1603 (2008).

RENN, J. A física clássica de cabeça para baixo: Como Einstein descobriu a teoria da relatividade especial. Revista Brasileira de Ensino de Física, v. 27, n. 1, p.27 - 36, (2004).

RODRIGUES, Carlos Daniel Ofugi. A inserção da teoria da relatividade no ensino médio. Dissertação de Mestrado UFSC - Programa de Pós-Graduação em Educação Científica e Tecnológica. Florianópolis, 2001.

SCHULZ, P.A. Duas nuvens ainda fazem sombra na reputação de Lorde Kelvin. Caderno Brasileiro de Ensino de Física, 29(4):509-512, 2007.

TERRAZZAN, E. A inserção da Física Moderna e Contemporânea no Ensino de Física na escola de $2^{\circ}$ grau. Cad. Cat. Ens. Fís. Florianópolis, v. 9, n. 3, p.209214, dez.1992.

WOLFF, Jeferson Fernando de Souza; MORS, Paulo Machado. Relatividade: a passagem do enfoque galileano para a visão de Einstein. Textos de apoio ao professor de física. v.16, n.5. Porto Alegre: UFRGS, Instituto de Física, 2005.

ZABALA, Antoni. A prática educativa: como ensinar. Trad. Ernani F. da Rosa Porto Alegre: ArtMed, 1998. 
APÊNDICE A - Produto Educacional 
Raquel da Silva Santos Freitas

PRODUTO EDUCACIONAL

Uma proposta didática para o ensino de tópicos da

Teoria da Relatividade Restrita

Juiz de Fora

2021 
Raquel da Silva Santos Freitas

Uma proposta didática para o ensino de tópicos da

Teoria da Relatividade Restrita

Este produto educacional foi desenvolvido no âmbito do Programa de Mestrado Nacional Profissional em Ensino de Física, polo 24 - UFJF/IF Sudeste-MG, como parte dos requisitos necessários à obtenção do título de Mestre em Ensino de Física.

Orientador: Prof. Dr.José Roberto Tagliati 
Prezado (a) Professor (a),

Apresentamos neste trabalho uma Sequência Didática que reúne, de maneira sucinta, algumas ferramentas educacionais para abordagem da Teoria da Relatividade Restrita. A inserção dessa temática tem como objetivo preparar os alunos para os novos conhecimentos que o mundo moderno e tecnológico reserva, ampliando assim o conhecimento de mundo por parte desses estudantes.

Dessa forma, esperamos que este produto educacional o auxilie no processo de tornar a aprendizagem mais interessante e significativa aos alunos.

\section{Introdução}

A aprendizagem é um processo cognitivo que acontece nos seres humanos independente da idade e do nível escolar. Ela está presente em ambientes escolares e não escolares, e representa uma mudança de comportamento em relação ao que foi apreendido.

Desse modo, analisando a prática educativa das aulas de Física em nossas escolas, identificamos diversos problemas no contexto dos processos de aprendizagem, entre eles, a grande ênfase na resolução de exercícios e a pouca preocupação com o desenvolvimento de habilidades para reflexão crítica e autocrítica dos conhecimentos que o aluno adquire.

Perante o exposto, este produto educacional foi elaborado para ser desenvolvido como uma Sequência Didática (SD), que compreende um conjunto de atividades planejadas etapa por etapa pelo professor, para que o entendimento do conteúdo seja alcançado pelos alunos.

Nossa SD foi planejada com objetivo de tornar o estudo da Teoria da Relatividade Restrita (TRR) mais acessível e compreensível aos alunos da educação básica. Com uma proposta de ensino baseada nos princípios da Teoria da Aprendizagem Significativa de David Ausubel, as atividades desenvolvidas priorizam a produção textual dos estudantes, para que seja possível perceber em cada aula os avanços alcançados pelos alunos.

A Sequência Didática foi construída a partir de um recorte dos conceitos de referencial, espaço e tempo para a abordagem dos conceitos básicos da TRR, como a dilatação temporal, a contração espacial, a relação de equivalência 
massa-energia, e suas correlações. Ela é proposta para 07 (sete) aulas, mas pode ser adaptada pelo professor, de acordo com sua realidade em sala de aula. É uma SD abrangente: nossa aplicação aconteceu para alunos do $3^{\circ}$ ano da Educação de Jovens e Adultos (EJA), mas pode ser trabalhada em qualquer série do ensino médio.

\section{Estrutura da sequência didática}

Nesta proposta didática, são aplicadas diferentes estratégias de ensino distribuídas em sete aulas, para que os alunos possam desenvolver uma compreensão acerca da Teoria da Relatividade Restrita. Cada aula tem duração de aproximadamente 50 minutos. O quadro a seguir apresenta aula por aula com suas respectivas metodologias e sugestões de uso.

Quadro 1: Descrição dos tópicos abordados na sequência didática.

\begin{tabular}{|c|c|c|}
\hline AULAS & TÓPICOS & OBJETIVOS DE APRENDIZAGEM \\
\hline Aula 1 & Questionário Investigativo & $\begin{array}{c}\text { Verificação do conhecimentos prévios dos } \\
\text { alunos por meio de um questionário } \\
\text { investigativo. }\end{array}$ \\
\hline Aula 2 & Espaço & $\begin{array}{c}\text { Localizar pontos no espaço Euclidiano. } \\
\text { Familiarizar-se com o uso de referenciais no } \\
\text { espaço. Estabelecer a diferença entre espaço } \\
\text { e distância. }\end{array}$ \\
\hline Aula 3 & Tempo & $\begin{array}{l}\text { Abordar o conceito de tempo e as diversas } \\
\text { maneiras de medi-lo. Discutir as diferenças } \\
\text { entre tempo emocional e tempo físico. }\end{array}$ \\
\hline Aula 4 & $\begin{array}{l}\text { Postulados da Teoria da } \\
\text { Relatividade Restrita (TRR). }\end{array}$ & $\begin{array}{c}\text { Apresentar os postulados da TRR: Invariância } \\
\text { das leis Físicas e Constância da Velocidade } \\
\text { da luz. Referenciais Inerciais. }\end{array}$ \\
\hline Aula 5 & $\begin{array}{c}\text { Dilatação do tempo e contração } \\
\text { do espaço. }\end{array}$ & $\begin{array}{l}\text { Analisar os fenômenos de dilatação do tempo } \\
\text { e contração do espaço com suas respectivas } \\
\text { equações. } \\
\text { Correção relativística no GPS. }\end{array}$ \\
\hline Aula 6 & Relação Massa Energia & $\begin{array}{c}\text { Apresentar a equação } \mathrm{E}=\mathrm{mc}^{2} \text {. } \\
\text { Mostrar usos e consequências: energia } \\
\text { nuclear e bomba atômica. }\end{array}$ \\
\hline Aula 7 & Avaliação & $\begin{array}{l}\text { Verificação da aprendizagem dos alunos por } \\
\text { meio de um questionário. }\end{array}$ \\
\hline
\end{tabular}

Fonte: Elaborado pela autora 


\section{Descrição da sequência didática}

\subsection{Aula 1: Questionário de Sondagem}

$\mathrm{Na} 1^{\mathrm{a}}$ aula é aplicado um questionário de sondagem, com o objetivo de fazer um levantamento dos conhecimentos prévios dos alunos, acerca dos conteúdos abordados em toda a sequência didática.

Os conhecimentos prévios dos estudantes são fundamentais para sua aprendizagem: de acordo com Ausubel, o aluno aprende a partir do que já sabe. Os conhecimentos prévios, hierarquicamente organizados, influenciam a aprendizagem significativa de novos conhecimentos.

Apresentamos a seguir o questionário a ser aplicado.

1. Constantemente ouvimos os termos 'tempo' e 'espaço', e também os utilizamos. Sendo assim, responda:

a) o que é espaço para você?

b) o que é tempo para você?

2. Faça abaixo uma representação do seu entendimento sobre o que é espaço. Essa representação pode ser uma música, um desenho, um texto, etc.

3. Faça abaixo uma representação do seu entendimento sobre o que é tempo. Essa representação pode ser uma música, um desenho, um texto, etc.

4. Uma criança constrói um carrinho usando massa de modelar (massinha). Assim que ela termina sua construção podemos afirmar que o carrinho passou a existir no espaço, isto é, o mesmo ocupa certo lugar. Podemos dizer também que ele começou a existir no tempo? Justifique sua resposta.

5. Suponha que você esteja viajando em um ônibus que não possua janelas, numa estrada perfeitamente plana, e que este ônibus seja extremamente silencioso (não é possível ouvir nenhum barulho que seja externo ao ônibus). Como você saberia se o ônibus está em movimento?

6. Suponha que você esteja viajando em um ônibus onde não há relógios ou outros meios de se medir o tempo. Esse ônibus não possui janelas e não há como ver se é dia ou noite. Ainda assim, haveria o tempo? Qual a sua opinião sobre isso? 
7. Em uma tempestade, antes de ouvirmos o barulho do trovão, vemos o clarão do relâmpago. Por que vemos primeiro a luz e somente depois ouvimos o som?

8. De qual dos cientistas citados abaixo você já ouviu falar? Assinale na lacuna ao lado do nome usando a seguinte escala:

0 - Nunca ouvi falar

1 - Ouvi falar, mas nada sei sobre sua área de trabalho e estudo.

2 - Ouvi falar e conheço o trabalho dele, porque alguém já me falou ou já li em livros ou internet.

Newton

Stephen Hawking
Galileu

Darwin
Einstein James Clerk Maxwell

9. O cientista Albert Einstein, em 1905, ficou famoso por sua abordagem da Teoria da Relatividade. Você conhece ou já ouviu falar da Teoria da Relatividade? Descreva o que você sabe ou pensa a respeito dessa teoria.

10. Qual ou quais das expressões abaixo você já viu em locais que não fossem em livros de Física ou de Matemática?
a) $E=m c^{2}$
b) $v=\frac{\Delta s}{\Delta t}$
c) $F_{R}=m \cdot a$
d) $a^{2}=b^{2}+c^{2}$
e) nenhuma

Após a leitura e análise do questionário respondido, é importante que o professor organize e direcione as próximas as aulas da sequência, a partir dos conhecimentos prévios dos alunos.

\subsection{Aula 2 - Espaço}

A proposta para essa aula é discutir com os alunos o conceito de referencial e diferenciar o conceito físico de que espaço é sinônimo de distância. Para isso os alunos deverão utilizar um sistema de eixos ortogonais para localizar um ponto no espaço (3 dimensões).

Para essa aula vamos usar: alfinetes coloridos, varetas, um sistema de eixos ortogonais confeccionado em isopor e papel milimetrado e o texto: Localização no Espaço - Coordenadas.

Sugerimos que a atividade seja realizada em grupos para promover o debate das ideias. 
Figura 1 - Materiais utilizados na atividade da aula 2

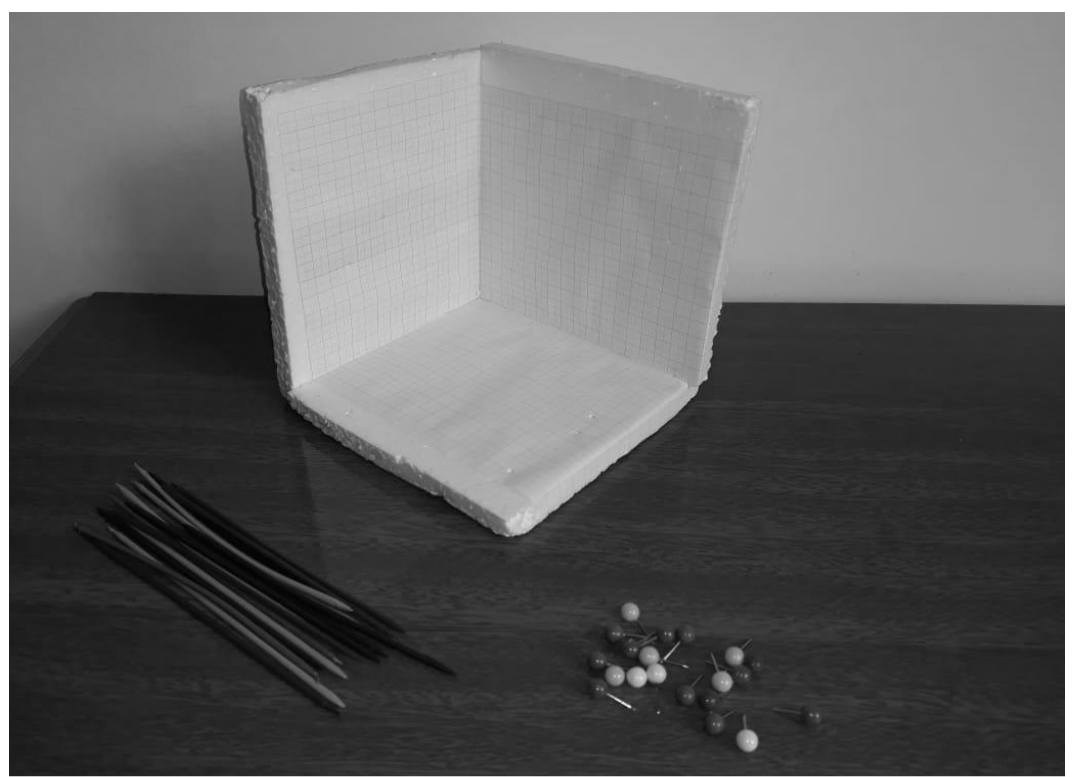

Fonte: Acervo pessoal

A atividade consiste em usar o aparato de isopor e papel milimetrado, como um sistema de referência, para localizar alguns objetos que podem ser colocados em alguns pontos da sala. Como exemplos de objetos temos: uma folha colada no quadro, uma caixa de sapatos no chão da sala, uma folha colada em uma das paredes laterais e uma caneta pendurada no teto por um fio.

Após a leitura comentada do texto, os grupos deverão representar em seu sistema de referência, os objetos relacionados.

Figura 2 - Alunos realizando a atividade

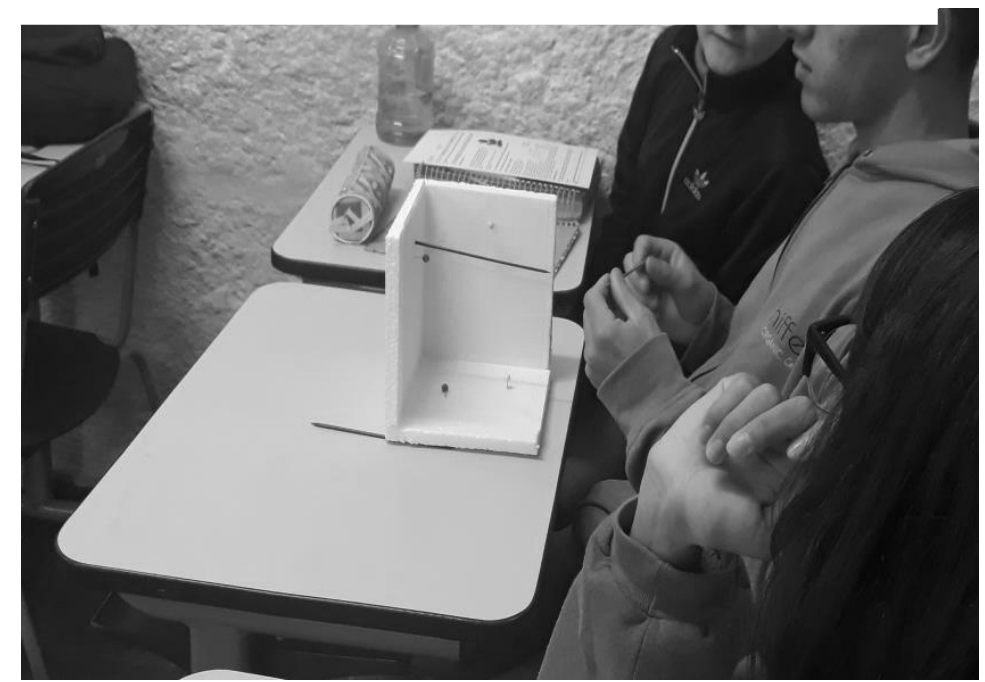

Fonte: Acervo pessoal 
Figura 3 - Aluno finalizando a atividade

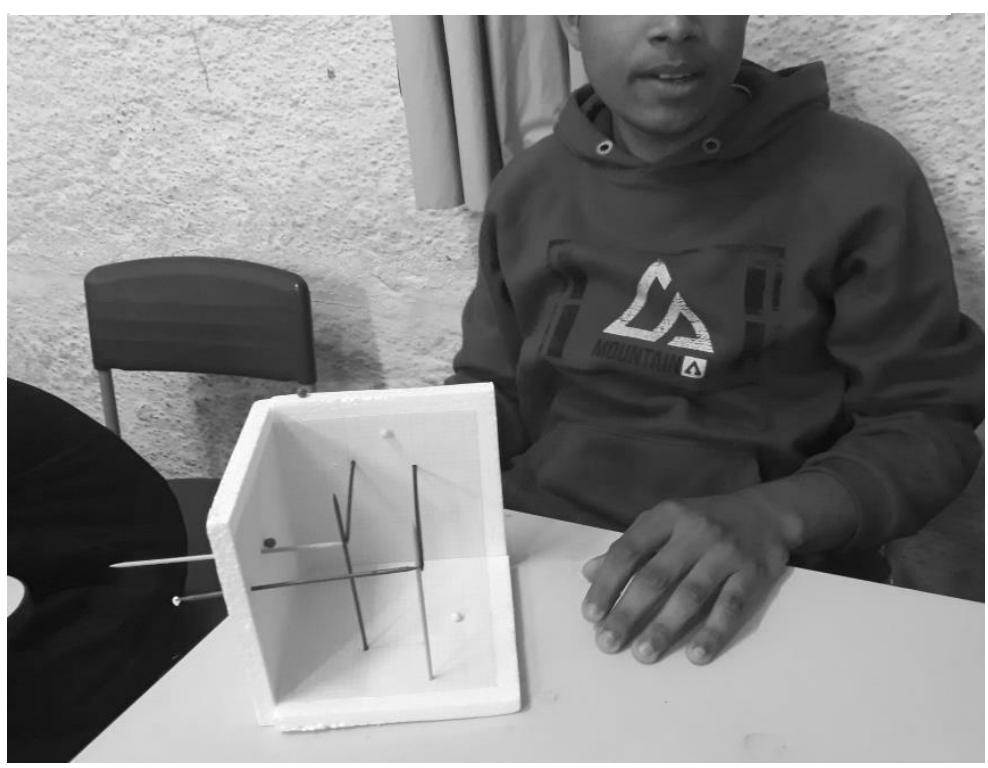

Fonte: Acervo pessoal

Figura 4 - Sistema de eixos ortogonais utilizado na atividade

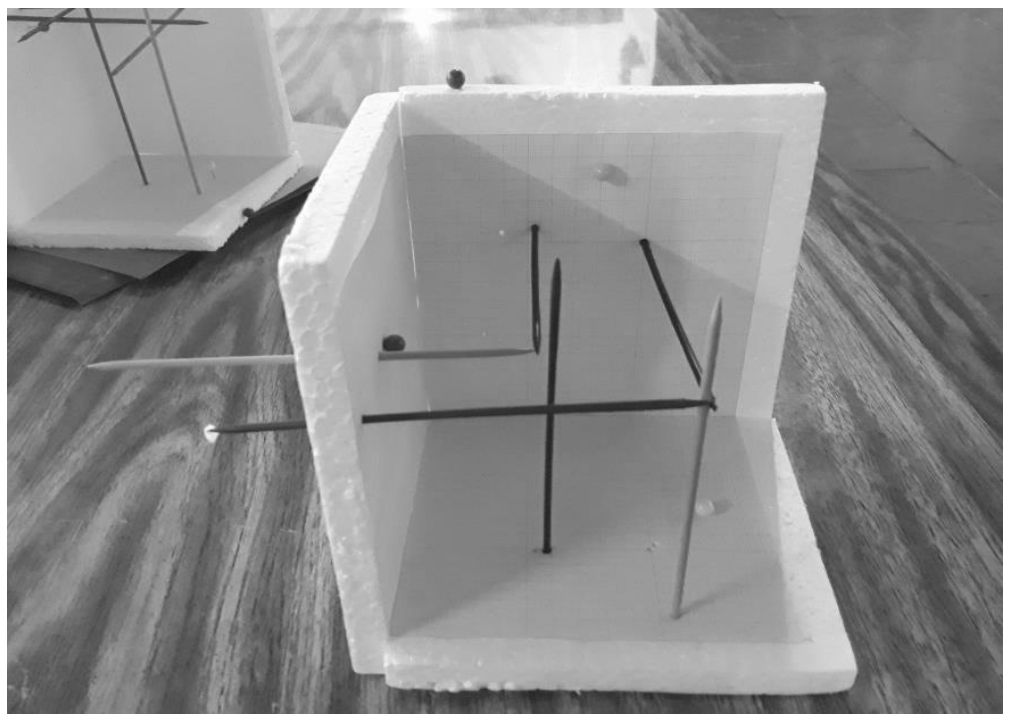

Fonte: Acervo pessoal

Ao final da atividade, propomos que cada grupo expresse verbalmente seu entendimento sobre os conceitos de referencial, espaço e distância. Esse momento é muito importante, pois o professor poderá dar suas contribuições a respeito do tema.

Como atividade complementar cada grupo deverá responder a atividade que se encontra ao final do texto de apoio desta aula. 


\section{Texto para a aula 2}

\section{Localização no Espaço: Coordenadas}

\section{LOCALIZACÃO NO ESPACO: COORDENADAS}

No espaço com o qual estamos acostumados a conviver, três são as dimensões: altura, largura e profundidade. É fácil visualizar um espaço assim! Uma das formas é pensar em uma sala: onde as duas paredes encontram o chão, temos bem claras as três dimensões.

O espaço em que vivemos é tridimensional, ou seja, podemos especificar a posição de qualquer local no espaço com três dimensões. Por exemplo, essas dimensões poderiam ser norte-sul, leste-oeste e de cima para baixo.

Pense no caso de estarmos naquele canto da sala em que as duas paredes se unem e encontram o chão. Nesta situação, se desejamos especificar a posição de um ponto qualquer da sala, podemos fazê-lo por meio de três números.

O primeiro seria o número de metros do ponto ao longo da linha onde a parede do lado e os pisos se encontram; o segundo seria o número

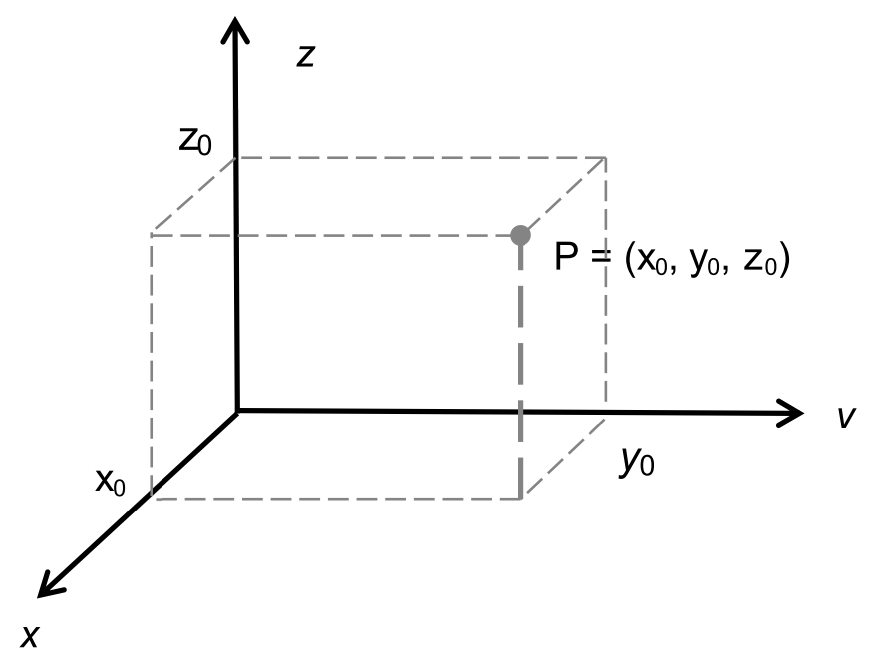
de metros do ponto ao longo de uma linha onde a parede de trás e o piso se encontram; e o terceiro seria o número de metros do ponto acima do piso ou ao longo da linha vertical onde as paredes se encontram no canto da sala. Os físicos chamam essas três linhas de eixos das coordenadas de um sistema de referência. Três números - as distâncias ao longo do eixo $x$, do eixo y e do eixo $z$ - especificarão a posição do ponto no espaço.

Responda:

Quantas dimensões existem no espaço em que vivemos e como podemos localizar a posição de um objeto no espaço? 


\subsection{AULA 3 - TEMPO}

Nesta aula deve-se discutir sobre o significado de tempo e as diferenças entre tempo emocional e tempo físico.

Como recurso didático para esta aula é proposto que os alunos assistam a um trecho do vídeo "Além do Cosmos - Episódio: O Tempo", disponível em: https://www.youtube.com/watch?v=6munxHulhgs. O trecho apresentado tem duração de aproximadamente 8 minutos (os primeiros 8 minutos do episódio), 'e aborda como o tempo tem sido medido ao longo da história. Após a exibição do vídeo será interessante e construtivo fazer alguns comentários sobre os conceitos abordados no vídeo.

Dando continuidade ao tema, para discutir sobre o significado de tempo e as diferenças entre tempo emocional e tempo físico, será feita uma análise da música "Semana que vem - Pitty".

Após ouvir e analisar a letra da música, os alunos deverão responder perguntas sobre o tema.

\section{MÚSICA SEMANA QUE VEM - PITTY}

Amanhã eu vou revelar

Depois eu penso em aprender

Daqui a uns dias eu vou dizer

$O$ que me faz querer gritar

No mês que vem tudo vai melhorar Só mais alguns anos e o mundo vai mudar

Ainda temos tempo até tudo explodir

Quem sabe quanto vai durar

Não deixe nada pra depois

Não deixe o tempo passar

Não deixe nada pra semana que vem

Porque semana que vem pode nem chegar

A partir de amanhã eu vou discutir

Da próxima vez eu vou questionar

$\mathrm{Na}$ segunda eu começo a agir

Só mais duas horas pra eu decidir

Não deixe nada pra depois
Não deixe o tempo passar

Não deixe nada pra semana que vem Porque semana que vem pode nem chegar

Esse pode ser o último dia de nossas vidas

Última chance de fazer tudo ter valido a pena

Diga sempre tudo o que precisa dizer Arrisque mais pra não se arrepender Nós não temos todo o tempo do mundo

E esse mundo já faz muito tempo

O futuro é o presente, e o presente já passou

Nada pra depois, não deixe o tempo passar

Não deixe nada pra semana que vem

Porque semana que vem pode nem chega 
Após análise e discussão sobre o conceito de tempo, responda:

1. Como você classificaria o tempo descrito na música Semana que vem? Quais as palavras usadas na música que conduzem a esse entendimento?

2. Leia o trecho: “... o futuro é o presente e o presente já passou..." Descreva o que você pensa a respeito dessa frase.

3. Descreva qual é a importância dessa entidade chamada tempo? Existem "tipos" de tempos diferentes? Justifique.

\subsection{Aula 4 - Postulados da Teoria da Relatividade Restrita}

Nesta $4^{\mathrm{a}}$ aula deve-se abordar os Postulados da Teoria da Relatividade Restrita (TRR). A aula é iniciada com um vídeo de aproximadamente 15 minutos, disponivel em https://www.youtube.com/watch?v=nf32ejhzTNQ.

Apresentando uma linguagem de fácil entendimento, inicialmente no vídeo é abordado o conceito físico de repouso e movimento, em seguida o conceito de referencial é definido. Após, é feita uma descrição da composição de velocidades para objetos, e descreve características importantes da luz, como o valor finito de sua velocidade e o fato de que essa velocidade independe do referencial da fonte que a emite. A seguir, são discutidos os fenômeno da Dilatação do Tempo e da Contração do Espaço, sendo também descrito o comportamento da partícula múon. Por fim, a equivalência massa-energia é abordada, e o vídeo termina com uma revisão dos tópicos vistos.

Buscando promover uma melhor assimilação dos conteúdos, é proposto inicialmente aos alunos assistiram ao vídeo completo, e na sequência, o professor deverá retomar parte por parte do vídeo. Esse momento poderá ser feito de forma dialogada e com o auxilio do quadro para anotações e explanação dos conceitos e conteúdos, tais como:

- Repouso e movimento dependem do referencial;

- Referencial inercial;

- Composição de velocidades;

- Constância da velocidade da luz; 
- Os postulados da Teoria da Relatividade;

- Espaço e tempo (absolutos de Newton x relativos de Einstein);

- Efeitos relativísticos observados somente com velocidades próximas da luz. No decorrer da aula foi possível retomar algumas perguntas feitas no questionário investigativo e discutir as respostas com base nos conteúdos da aula.

\subsection{Aula 5 - Dilatação do Tempo e Contração do Espaço}

Esta aula deverá ser iniciada retomando os conceitos vistos na aula anterior sobre a Teoria da Relatividade. Os postulados da TRR devem ser novamente enunciados e os efeitos da contração do espaço e da dilatação do tempo, e suas respectivas equações, devem ser analisados a partir de situações relativísticas, com o auxilio do quadro de giz para anotações.

Visando uma interdisciplinaridade, a dilatação temporal será exemplificada por uma abordagem ao funcionamento do GPS (Sistema de Posicionamento Global). Para isso, os alunos receberão um texto de divulgação científica e um infográfico (anexos) para analisar a correção relativística, necessária para o bom funcionamento do GPS.

O professor poderá realizar a leitura do texto em voz alta para que sejam feitas considerações e reflexões a respeito do tema.

\section{Texto para a aula 5}

\section{Seu celular mastiga fórmulas de Einstein para o Waze funcionar}

\section{Sem uma mão da Teoria da Relatividade, nenhum aplicativo que usa GPS funcionaria direito. Entenda como o legado do físico alemão garante sua volta para casa}

Você põe a roupinha de astronauta, sobe em uma nave espacial, afunda o pé no acelerador e esquece ele lá. Esse é um mundo imaginário, então o motor é bom o suficiente para te levar a quase 1,08 bilhão de quilômetros por hora - a velocidade da luz.

É aí que algo bizarro acontece. O tempo começa a passar mais devagar para você, que está em movimento, do que para quem ficou sentado no sofá de casa, lá na Terra. Quando você volta, ainda jovem e saudável, seus pais já morreram, seu cônjuge está no asilo e seus filhos terminaram a pós-graduação.

Você já viu a cena acima em várias matérias da SUPER - e também no filme Interestelar, de Christopher Nolan. Ela é um jeito clichê e muito eficiente de explicar uma das consequências da Teoria da Relatividade de Albert Einstein: o tempo passa diferente para quem está em movimento. Se a nave atingisse, por exemplo, $92 \%$ da velocidade da luz, cada 1 minuto passado em seu interior corresponderia a 2 minutos e 39 segundos terráqueos (quem quiser fazer essa conta curiosa pode usar uma calculadora relativística). 
"Legal", você dirá, "ainda bem que o motorista do meu ônibus alcança só $10 \%$ da velocidade da luz. É o suficiente para eu achar que vou morrer quando alguém dá o sinal em cima da hora, mas não vai me impedir de ver meus filhos crescerem, certo?" Errado.

Às vezes a relatividade afeta sua vida na prática. $E$ você só não percebe porque a engenharia já deu um jeito no problema. É o caso do Waze, do Uber e dos demais aplicativos que dependem do GPS para funcionar.

É o seguinte: a Terra tem 12,7 mil quilômetros de diâmetro, e dá uma volta em torno de si mesma a cada 24 horas. Se você fizer as contas, descobrirá que alguém que está de pé na linha do Equador gira a 1,6 mil km/h (os físicos da UFRGS explicam melhor aqui).

Mantenha isso em mente, e vamos partir para um exercício mental: imagine que há uma pessoa vivendo em um buraco muito, muito fundo - tão fundo que ela esteja consideravelmente mais perto do núcleo do planeta que uma pessoa normal, do tipo que vive na superfície. Esse homem das cavernas também está girando, mas mais devagar, porque está mais perto do centro da esfera. Pelo mesmo motivo que um carro de Fórmula 1 ultrapassa o outro quando faz as curvas por dentro, mais fechadas - mesmo que ele não esteja de fato mais rápido que o oponente. Se nosso homem da caverna profunda está se movendo mais devagar, dizem as equações de Einstein, isso significa que o tempo está passando um bocado (um bocadinho bem pequeno mesmo) mais rápido para ele do que para você. Um mastodontilhão de frações de milésimos de segundo. Uma diferença imperceptível, mas ainda é uma diferença.

Agora vamos fazer o exercício oposto: é o caso de um satélite geoestacionário que está na órbita da Terra, a 36 mil quilômetros de altitude, mas gira em torno de nós sempre usando um ponto fixo na superfície do planeta como referência. Ele é como um Fórmula 1 azarado, que está fazendo a curva muito, mas muito por fora. Por causa disso, ele precisa girar bem mais rápido para acompanhar o nosso ritmo aqui embaixo. Se ele está mais rápido, o tempo, para ele, passa mais devagar. Em relação a nós, ele é o oposto do Fred Flintstone lá embaixo.

Os satélites que fazem o GPS funcionar flutuam mais baixo - "só" 20 mil km - mas completam duas órbitas diárias em torno da Terra. Ou seja: estão bem mais rápidos que nossos $1,6 \mathrm{mil} \mathrm{km} / \mathrm{h}$ - cerca de $14 \mathrm{mil} \mathrm{km} / \mathrm{h}$. Por causa disso, o tempo passa mais devagar para eles do que para nós. Para ser mais preciso, 7 microssegundos de atraso diário (essa conta, ainda bem, um físico chamado Neil Ashby já fez para nós).

Além dessa, há outra variável: ele está mais distante da área de influência do campo gravitacional da Terra. Como a gravidade distorce o espaço e o tempo, também é preciso levar em consideração a diferença da atuação dessa força aqui na superfície e lá no alto. Faça mais essa conta e você descobrirá que o tempo, para o satélite, está passando 45 microssegundos mais rápido todos os dias. Subtraia esses dois números (45 e -7) e você terá um delay de 38 microssegundos a cada 24 horas entre o GPS e a Terra.

Os receptores de GPS, como seu celular, calculam a própria posição na Terra cruzando informações fornecidas por no mínimo três dos 24 satélites da rede. $O$ resultado é uma precisão de até $10 \mathrm{~m}$. Mas se o tempo estiver passando em velocidades diferentes aqui na superfície e a 20 mil km de altitude, essa diferença de frações de segundo, antes discreta, vai se acumular o suficiente para se tornar perceptível na escala temporal humana. E a sua posição, com o passar dos dias, será calculada com distorções cada vez mais graves.

A solução para isso é colocar os relógios atômicos que comandam os satélites para rodar mais devagar, compensando a distorção. E ensinar o celular a fazer contas usando a Teoria da Relatividade para evitar erros. Agora você já sabe porque a bateria acaba tão rápido quando o localizador está ativado: haja caloria para seguir o raciocínio do maior gênio da história da Física.

Fonte: Revista Super Interessante - Blog Super Novas. Disponível em: https://super.abril.com.br/blog/supernovas/seu-celular-mastiga-formulas-de-einstein-para- 


\section{INFOGRÁFICO FUNCIONAMENTO DO GPS}

\section{Como funciona}

O Sistema de Posicionamento Global

(GPS) permite conhecer a posição de um objeto em qualquer parte do mundo.

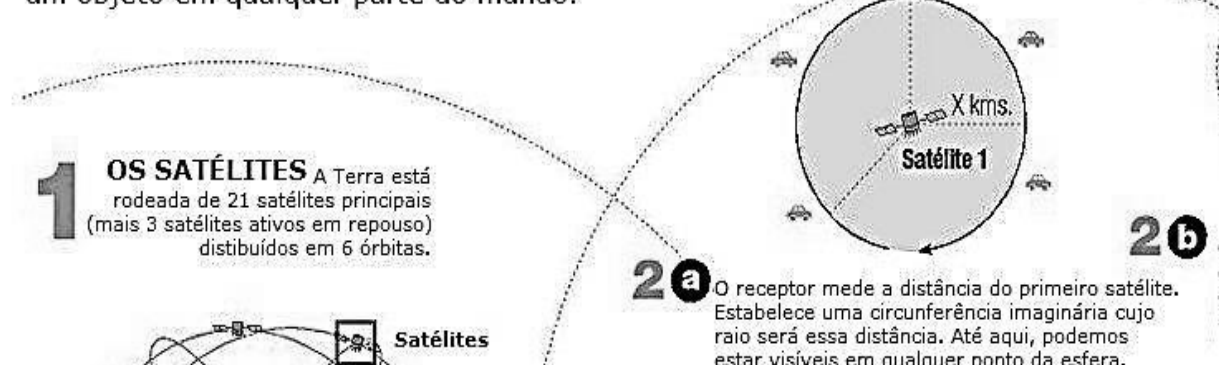

A TRIANGULAÇÃO o sistema GPS

se baseia na medição da distância existente
entre o receptor e ao menos 3 satélites

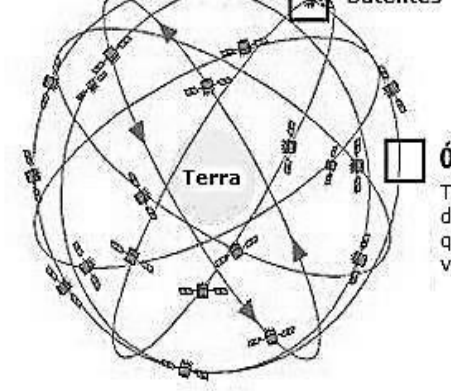
podemos
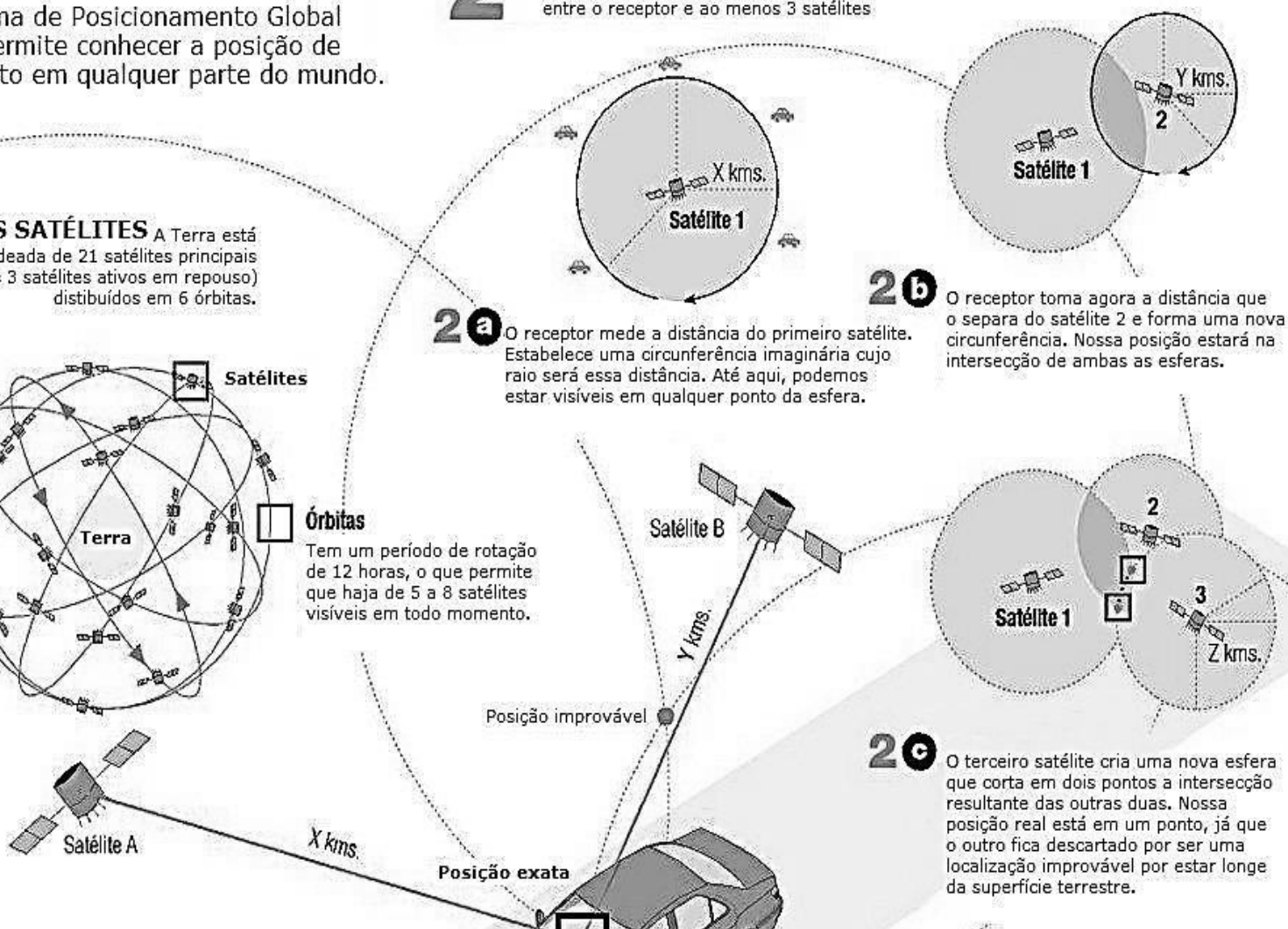

O PROCESSAMENTO O receptor recebe seguinte informação: 0 que três satélites seguinte informação: 0 que três satélites
captame as características de suas órbitas. captam e as características de suas órbitas.
Processa todos esses dados e obtém a Processa todos esses dados e obtém a
posição exata do carro. A margem de erro oscila entre 30 e 100 metros.

Tem um período de rotação de 12 horas, o que permite visíveis em todo momento.
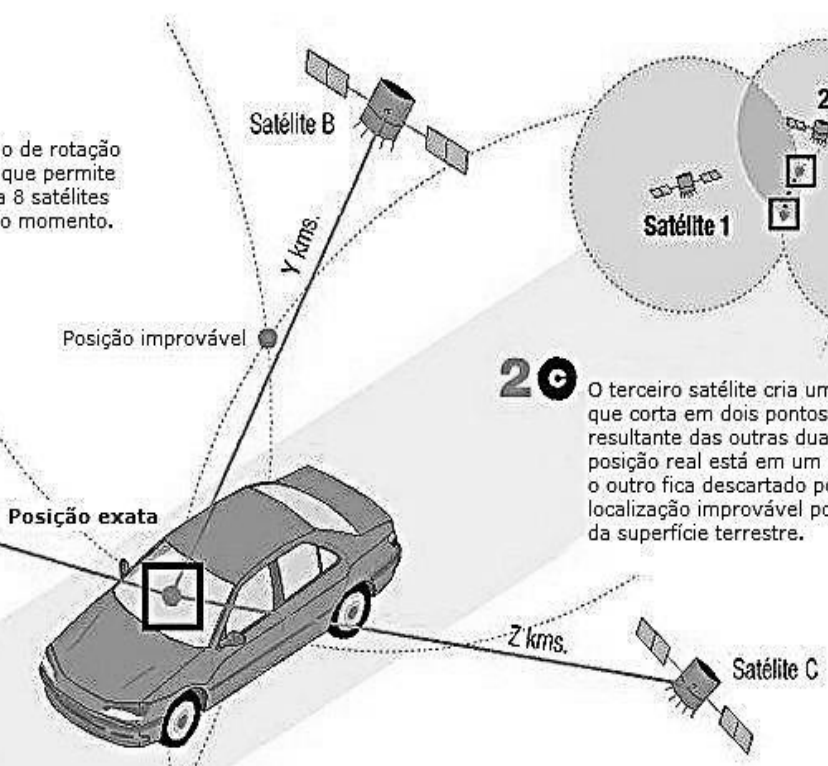

NOTA: O receptor está projetado para receber sinais de 3 satélites. Quanto Mais sinais captar, mais preciso será o cálculo

Infografía: Amaya Verde Fonte : Leandro de Haro y Ariet, ingeniero de telecomunicaciones y prolesor de la UPM. Tradução: Bidu Corretora

Fonte: https://br.pinterest.com/pin/810225789182157083/ 


\subsection{Aula 6 - Relação de equivalência massa-energia}

Nesta aula será abordada a relação de Equivalência Massa-Energia utilizando-se a equação $E=m . c^{2}$.

Para a realização da aula será utilizado um material de apoio impresso, dois textos. O professor deve fazer a leitura dos textos fazendo as considerações pertinentes ao tema. O professor também poderá resolver alguns exercícios sobre o tema no quadro de giz.

\section{TEXTO 1}

\section{Massa e Energia}

Muita gente gosta de tomar aquele copão de chocolate em frente da televisão. Quente no friozinho e geladão no calor uma caneca sempre vai bem.

Uma caneca típica de chocolate tem mais ou menos $200 \mathrm{ml}$, como possui densidade próxima da água, o chocolate na caneca tem massa de mais ou menos $200 \mathrm{~g}$. O chocolate possui muita energia química facilmente aproveitada pelo corpo e é por isso que é considerado um energético eficiente quando estamos estudando ou praticando esportes.

Contudo, o chocolate não possui somente energia em suas ligações químicas. Pela relatividade, a sua própria massa pode ser transformada em energia! ( $\mathrm{Na}$ verdade a massa de qualquer coisa!).

Segundo a relatividade, esses $200 \mathrm{~g}$ de chocolate podem ser convertidos em energia, pois $E=m c^{2}$, ou seja, a massa de alguma coisa pode se transformar em energia, mas quanto? É simples, vamos lá:

$$
\begin{aligned}
& \mathrm{m}=200 \mathrm{~g}=0,2 \mathrm{~kg}=2 \cdot 10^{-1} \mathrm{~kg} \\
& \mathrm{c}^{2}=\left(3 \cdot 10^{8} \mathrm{~m} / \mathrm{s}\right)^{2}=9 \cdot 10^{16} \mathrm{~m}^{2} / \mathrm{s}^{2}
\end{aligned}
$$

Então:

$$
\begin{aligned}
& E=m \cdot c^{2}=2 \cdot 10^{-1} \mathrm{~kg} \times 9 \cdot 10^{16} \mathrm{~m}^{2} / \mathrm{s}^{2} \\
& E=1,8 \cdot 10^{16} \mathrm{~J} \\
& E=18000000000000000 \mathrm{~J}
\end{aligned}
$$

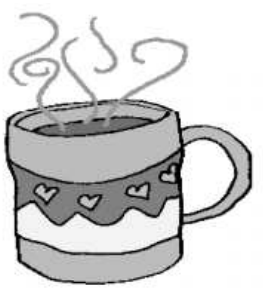

É uma quantidade muito grande de energia não acha?

Vamos supor que utilizássemos essa energia para manter ligado um aparelho de TV de aproximadamente $100 \mathrm{~W}$. Por quanto tempo a TV funcionaria?

Fazendo as contas:

$$
P=\frac{\Delta E}{\Delta t} \longrightarrow \Delta t=\frac{\Delta E}{P} \longrightarrow \begin{aligned}
\Delta t & =\frac{1,8 \cdot 1016 \mathrm{~J}}{10^{2} \mathrm{~J} \cdot \mathrm{s}^{-1}} \\
\Delta t & =1,8 \cdot 10^{14} \text { segundos }
\end{aligned}
$$

Só para termos uma ideia de quanto tempo é isso, um ano tem 365 dias, cada dia tem 24 horas e cada hora tem 3600 segundos. Então: 
Usando uma regra simples de proporcionalidade, teremos:

$\begin{array}{ll}1 \text { ano } & 3,2 \cdot 10^{7} \mathrm{~s} \\ \Delta \mathrm{t} \text { anos } & 1,8 \cdot 10^{14} \mathrm{~s}\end{array}$

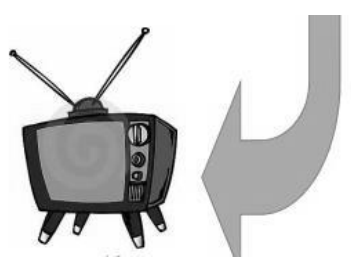

Portanto $\Delta t=5625000$ de anos, ou seja, quase 6 bilhões de anos!

Se a TV durasse tanto tempo, poderia ficar ligada por quase 6 bilhões de anos, com a energia de uma simples caneca de chocolate de $200 \mathrm{~g}$, mais ou menos a idade do planeta Terra!

Fonte: http://atp.usp.br:9080/rid=1LRSXM3P6-29LTCH8-XX/REA.4.4.1.pdf

\section{Texto 2}

\section{A Energia Nuclear e a Bomba Atômica}

Durante a Segunda Guerra Mundial, em agosto de 1945, os americanos bombardearam Hiroshima e Nagasaki, duas cidades japonesas, estreando de forma cruel uma nova tecnologia: a explosão de bombas de fissão.

Por que uma bomba atômica tem um poder tão destruidor? De onde vem tanta energia? Tudo se explica pela equivalência massa-energia.

Se somarmos a massa dos núcleons separados, veremos que sempre se obtém um valor maior que a massa total do núcleo.

Essa diferença na massa $\Delta m=m$ núcleons $-m_{\text {núcleo }}$ é conhecida como "defeito de massa".

Mas onde foi parar a massa que está faltando? A soma das partes não deveria ser igual ao todo?

$\mathrm{Na}$ verdade, não está faltando nada. A diferença de massa fica armazenada, na forma de uma energia potencial $\Delta E=\Delta m \cdot c^{2}$, nas ligações entre os núcleons e, por isso mesmo, chamada de "energia de ligação". Isso está plenamente de acordo com a equivalência massa-energia.

Quando ocorre fissão (ou quebra) de um núcleo atômico, essa energia pode ser liberada. Se, por exemplo, bombardeamos um núcleo de urânio com nêutrons, ele se quebra em duas partes mais leves e libera energia. A equação que mostra o fenômeno é:

$$
{ }_{92}^{235} \mathrm{U} \rightarrow{ }_{54}^{140} \mathrm{Xe}+{ }_{38}^{94} \mathrm{Sr}+{ }_{0}^{1} \mathrm{n}+{ }_{0}^{1} \mathrm{n}+\Delta \mathrm{E}
$$

Note que teremos dois novos nêutrons liberados e eles podem colidir com outros átomos de urânio, ainda íntegros, provocando nova fissão e assim por diante. Essa reação em cascata desencadeia um processo violento de liberação de energia. Na equação anterior, para cada átomo de urânio fissurado temos a 
liberação de $\Delta \mathrm{E}=\Delta \mathrm{m} \cdot \mathrm{c}^{2}=200 \mathrm{Mev}\left(1 \mathrm{Mev}=1,6 \cdot 10^{-13} \mathrm{~J}\right)$. Imagine todos os átomos liberando essa energia ao mesmo tempo, o montante final será enorme.

A Bomba de Hiroshima, Little Boy, possuía $64 \mathrm{~kg}$ de Urânio, dos quais apenas $700 \mathrm{~g}$ sofreu fissão nuclear. Desses $700 \mathrm{~g}$, apenas $0,7 \mathrm{~g}$ virou energia!

Fonte: http://atp.usp.br:9080/rid=1LRSXM3P6-29LTCH8-XX/REA.4.4.1.pdf

\section{Atividade}

Como exercício, calcule aproximadamente quantos joules de energia foram liberados pela Little Boy sobre Hiroshima. Quantos átomos de Urânio sofreram fissão aproximadamente? Você acha muito? Quantos átomos possui uma caneca de chocolate quente? (dica: use o número de Avogadro e considere o chocolate como água, $\mathrm{H}_{2} \mathrm{O}$, para facilitar. Não tenha dúvida, pesquise!)

\subsection{Aula 7 - Avaliação}

Na última aula da sequência didática é aplicado um questionário avaliativo para verificação da aprendizagem dos conteúdos apresentados e estudados.

É importante destacar que, na avaliação que será aplicada aos alunos, o professor deve procurar elementos que evidenciem a aprendizagem significativa. Os alunos deverão expressar o conhecimento adquirido e absorvido durante as aulas de TRR por meio de questões discursivas com análise de conceitos e aplicações que envolvem resoluções matemáticas.

\section{Questionário avaliativo}

1. Identifique a proposição correta

A) A Terra é um corpo em repouso.

B) Uma pessoa sentada num banco de jardim está em repouso.

C) Se um corpo estiver em repouso em relação a um dado referencial, então estará em movimento em relação a qualquer outro referencial.

D) Para afirmar que um corpo está em repouso ou em movimento não dependemos do referencial adotado.

E) Um corpo pode estar em repouso em relação a um referencial e em movimento em relação a outro.

2. De acordo com os conceitos estudados em nossas aulas sobre a Teoria da Relatividade Restrita, descreva duas características sobre a velocidade da luz.

3. Durante nossas aulas estudamos sobre os fenômenos relativísticos da dilatação temporal e da contração do comprimento. Desta forma, responda:

a) O que é necessário para que este fenômeno aconteça? 
b) Por que tais fenômenos não são observados em nosso cotidiano?

4. (UFRN) Bastante envolvida com seus estudos para a prova do vestibular, Silvia selecionou o seguinte texto sobre Teoria da Relatividade para mostrar a sua colega Tereza:

À luz da Teoria da Relatividade Especial, as medidas de comprimento, massa e tempo não são absolutas quando realizadas por observadores em referenciais inerciais diferentes. Conceitos inovadores como massa relativística, contração de Lorentz e dilatação temporal desafiam o senso comum. Um resultado dessa teoria e que as dimensões de um objeto são máximas quando medidas em repouso em relação ao observador.

Quando o objeto se move com velocidade $V$, em relação ao observador, o resultado da medida de sua dimensão paralela à direção do movimento e menor do que o valor obtido quando em repouso. As suas dimensões perpendiculares à direção do movimento, no entanto, não são afetadas.

Depois de ler esse texto para Tereza, Silvia pegou um cubo de lado $L_{o}$ que estava sobre a mesa e fez a seguinte questão para ela:

Como seria a forma desse cubo se ele estivesse se movendo, com velocidade relativística constante, conforme direção indicada na figura abaixo?

A resposta correta de Tereza a essa pergunta foi:

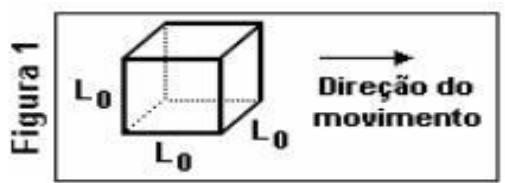

a)

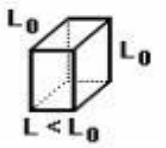

b)

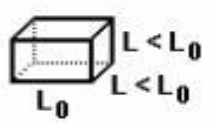

c)

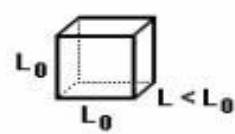

d)

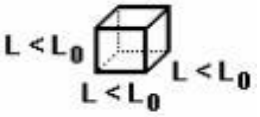

5. Um exemplo conhecido da aplicação do fenômeno relativístico da dilatação temporal e dos Postulados da Teoria da Relatividade Restrita de Einstein é o "paradoxo dos gêmeos".

Imagine que gêmeos idênticos são separados ainda crianças, um deles permanece na Terra enquanto o outro é colocado em uma nave espacial para viajar a uma velocidade de $80 \%$ da velocidade da luz no vácuo $(0,8 \mathrm{c})$. Depois de passados 70 anos para o gêmeo que ficou na Terra o gêmeo astronauta volta e algo curioso é observado, o gêmeo que ficou aqui na Terra teria a aparência de estar mais velho que seu irmão.

De acordo com as informações acima, qual seria a idade do irmão gêmeo astronauta?
A) 35 anos
B) 42 anos
C) 60 anos
D) 70 anos
E) 85 anos

6. Considere, hipoteticamente, que uma batata de $100 \mathrm{~g}$ de massa, em repouso, fosse integralmente transformada em energia. Sabendo que $1 \mathrm{kWh}=3,6.10^{6} \mathrm{~J}$, qual seria a quantidade de energia em kWh produzida na conversão massa- energia acima citada?

Dado: $\mathrm{c}=3.10^{8} \mathrm{~m} / \mathrm{s}$

7. Escreva um pequeno comentário ou sugestão sobre as aulas de Teoria da Relatividade Restrita. 


\section{APÊNDICE B - Questionário de sondagem}

1. Constantemente ouvimos os termos 'tempo' e 'espaço', e também os utilizamos. Sendo assim, responda:

a) o que é espaço para você?

b) o que é tempo para você?

2. Faça abaixo uma representação do seu entendimento sobre o que é espaço. Essa representação pode ser uma música, um desenho, um texto, etc.

3. Faça abaixo uma representação do seu entendimento sobre o que é tempo. Essa representação pode ser uma música, um desenho, um texto, etc.

4. Uma criança constrói um carrinho usando massa de modelar (massinha). Assim que ela termina sua construção podemos afirmar que o carrinho passou a existir no espaço, isto é, o mesmo ocupa certo lugar. Podemos dizer também que ele começou a existir no tempo? Justifique sua resposta.

5. Suponha que você esteja viajando em um ônibus que não possua janelas, numa estrada perfeitamente plana, e que este ônibus seja extremamente silencioso (não é 
possível ouvir nenhum barulho que seja externo ao ônibus). Como você saberia se o ônibus está em movimento?

6. Suponha que você esteja viajando em um ônibus onde não há relógios ou outros meios de se medir o tempo. Esse ônibus não possui janelas e não há como ver se é dia ou noite. Ainda assim, haveria o tempo? Qual a sua opinião sobre isso?

7. Em uma tempestade, antes de ouvirmos o barulho do trovão, vemos o clarão do relâmpago. Por que vemos primeiro a luz e somente depois ouvimos o som?

8. De qual dos cientistas citados abaixo você já ouviu falar? Assinale na lacuna ao lado do nome usando a seguinte escala:

0 - Nunca ouvi falar

1 - Ouvi falar, mas nada sei sobre sua área de trabalho e estudo.

2 - Ouvi falar e conheço o trabalho dele, porque alguém já me falou ou já li em livros ou internet.

Newton

Stephen Hawking

Galileu

Darwin

Einstein

James Clerk Maxwell

9. O cientista Albert Einstein, em 1905, ficou famoso por sua abordagem da Teoria da Relatividade. Você conhece ou já ouviu falar da Teoria da Relatividade? Descreva o que você sabe ou pensa a respeito dessa teoria.

10. Qual ou quais das expressões abaixo você já viu em locais que não fossem em livros de Física ou de Matemática?
a) $E=m c^{2}$
b) $v=\frac{\Delta s}{\Delta t}$
c) $F_{R}=m \cdot a$
d) $a^{2}=b^{2}+c^{2}$
e) nenhuma 


\section{APÊNDICE C - Localização no Espaço: Coordenadas}

\section{LOCALIZACÃOO NO ESPAÇO: COORDENADAS}

No espaço com o qual estamos acostumados a conviver, três são as dimensões: altura, largura e profundidade. É fácil visualizar um espaço assim! Uma das formas é pensar em uma sala: onde as duas paredes encontram o chão, temos bem claras as três dimensões.

O espaço em que vivemos é tridimensional, ou seja, podemos especificar a posição de qualquer local no espaço com três dimensões. Por exemplo, essas dimensões poderiam ser norte-sul, leste-oeste e de cima para baixo.

Pense no caso de estarmos naquele canto da sala em que as duas paredes se unem e encontram o chão. Nesta situação, se desejamos especificar a posição de um ponto qualquer da sala, podemos fazê-lo por meio de três números.

O primeiro seria o número de metros do ponto ao longo da linha onde a parede do lado e os pisos se encontram; o segundo seria o número de metros do ponto ao longo de uma linha onde a parede de trás e o piso se encontram; e o terceiro seria o número de metros do ponto acima do piso ou ao longo da linha vertical onde as paredes se encontram no

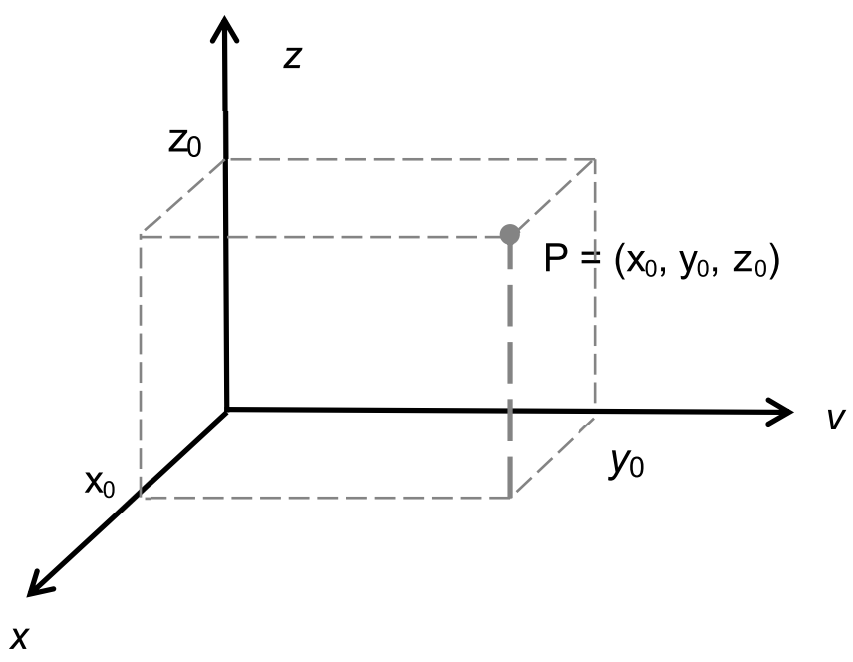
canto da sala. Os físicos chamam essas três linhas de eixos das coordenadas de um sistema de referência. Três números - as distâncias ao longo do eixo $\mathrm{x}$, do eixo y e do eixo $z$ - especificarão a posição do ponto no espaço.

Responda:

Quantas dimensões existem no espaço em que vivemos e como podemos localizar a posição de um objeto no espaço? 


\section{APÊNDICE D - Questionário: Música Semana que vem}

Após análise e discussão sobre o conceito de tempo, responda:

1. Como você classificaria o tempo descrito na música Semana que vem? Quais as palavras usadas na música que conduzem a esse entendimento?

2. Leia o trecho: “... o futuro é o presente e o presente já passou...” Descreva o que você pensa a respeito dessa frase.

3. Descreva qual é a importância dessa entidade chamada tempo? Existem "tipos" de tempos diferentes? Justifique. 


\section{APÊNDICE E - Questionário Avaliativo}

1. Identifique a proposição correta

A) A Terra é um corpo em repouso.

B) Uma pessoa sentada num banco de jardim está em repouso.

C) Se um corpo estiver em repouso em relação a um dado referencial, então estará em movimento em relação a qualquer outro referencial.

D) Para afirmar que um corpo está em repouso ou em movimento não dependemos do referencial adotado.

E) Um corpo pode estar em repouso em relação a um referencial e em movimento em relação a outro.

2. De acordo com os conceitos estudados em nossas aulas sobre a Teoria da Relatividade Restrita, descreva duas características da velocidade da luz.

3. Durante nossas aulas estudamos sobre os fenômenos relativísticos da dilatação temporal e da contração do comprimento. Em relação a isso, responda:

a) O que é necessário para que esses fenômenos aconteçam?

b) Por que tais fenômenos não são observados em nosso cotidiano?

4. (UFRN) Bastante envolvida com seus estudos para a prova do vestibular, Silvia selecionou o seguinte texto sobre Teoria da Relatividade para mostrar a sua colega Tereza:

À luz da Teoria da Relatividade Especial, as medidas de comprimento, massa e tempo não são absolutas quando realizadas por observadores em referenciais inerciais diferentes. Conceitos inovadores como massa relativística, contração de Lorentz e dilatação temporal desafiam o senso comum. Um resultado dessa teoria e que as dimensões de um objeto são máximas quando medidas em repouso em relação ao observador.

Quando o objeto se move com velocidade $V$, em relação ao observador, o resultado da medida de sua dimensão paralela à direção do movimento e menor do que o valor obtido quando em repouso. As suas dimensões perpendiculares à direção do movimento, no entanto, não são afetadas.

Depois de ler esse texto para Tereza, Silvia pegou um cubo de lado $L_{0}$ que estava sobre a mesa e fez a seguinte questão para ela:

Como seria a forma desse cubo se ele estivesse se movendo, com velocidade relativística constante, conforme direção indicada na figura abaixo?

A resposta correta de Tereza a essa pergunta foi:

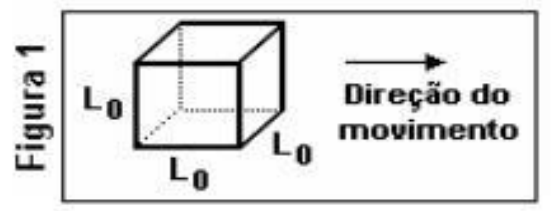

a)

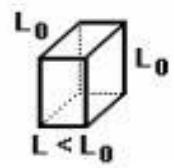

b)

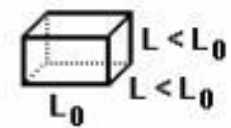

c)

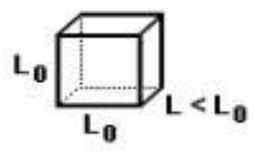

d)

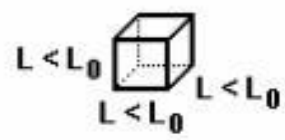


5. Um exemplo conhecido da aplicação do fenômeno relativístico da dilatação temporal e dos Postulados da Teoria da Relatividade Restrita de Einstein é o "paradoxo dos gêmeos".

Imagine que gêmeos idênticos são separados ainda crianças, um deles permanece na Terra enquanto o outro é colocado em uma nave espacial para viajar a uma velocidade de $80 \%$ da velocidade da luz no vácuo $(0,8 \mathrm{c})$. Depois de passados 70 anos para o gêmeo que ficou na Terra o gêmeo astronauta volta e algo curioso é observado, o gêmeo que ficou aqui na Terra teria a aparência de estar mais velho que seu irmão.

De acordo com as informações acima, qual seria a idade do irmão gêmeo astronauta?
A) 35 anos
B) 42 anos
C) 60 anos
D) 70 anos
E) 85 anos

6. Considere, hipoteticamente, que uma batata de $100 \mathrm{~g}$ de massa, em repouso, fosse integralmente transformada em energia. Sabendo que $1 \mathrm{kWh}=3,6.10^{6} \mathrm{~J}$, qual seria a quantidade de energia em kWh produzida na conversão massa-energia acima citada?

Dado: $\mathrm{c}=3.10^{8} \mathrm{~m} / \mathrm{s}$

7. Escreva um pequeno comentário ou sugestão sobre as aulas de Teoria da Relatividade Restrita. 


\section{ANEXO A - Música Semana Que Vem - Pitty}

Amanhã eu vou revelar

Depois eu penso em aprender

Daqui a uns dias eu vou dizer

$\mathrm{O}$ que me faz querer gritar

No mês que vem tudo vai melhorar

Só mais alguns anos e o mundo vai mudar

Ainda temos tempo até tudo explodir

Quem sabe quanto vai durar

Não deixe nada pra depois

Não deixe o tempo passar

Não deixe nada pra semana que vem

Porque semana que vem pode nem chegar

A partir de amanhã eu vou discutir

Da próxima vez eu vou questionar

$\mathrm{Na}$ segunda eu começo a agir

Só mais duas horas pra eu decidir

Não deixe nada pra depois

Não deixe o tempo passar

Não deixe nada pra semana que vem

Porque semana que vem pode nem chegar

Esse pode ser o último dia de nossas vidas

Última chance de fazer tudo ter valido a pena

Diga sempre tudo o que precisa dizer

Arrisque mais pra não se arrepender

Nós não temos todo o tempo do mundo

E esse mundo já faz muito tempo

O futuro é o presente, e o presente já passou

Nada pra depois, não deixe o tempo passar

Não deixe nada pra semana que vem

Porque semana que vem pode nem chegar 


\title{
ANEXO B - Seu celular mastiga fórmulas de Einstein para o Waze funcionar
}

\author{
Seu celular mastiga fórmulas de Einstein para o Waze funcionar
}

\author{
Sem uma mão da Teoria da Relatividade, nenhum aplicativo que usa GPS \\ funcionaria direito. Entenda como o legado do físico alemão garante sua volta \\ para casa
}

Você põe a roupinha de astronauta, sobe em uma nave espacial, afunda o pé no acelerador e esquece ele lá. Esse é um mundo imaginário, então o motor é bom o suficiente para te levar a quase 1,08 bilhão de quilômetros por hora - a velocidade da luz.

É aí que algo bizarro acontece. O tempo começa a passar mais devagar para você, que está em movimento, do que para quem ficou sentado no sofá de casa, lá na Terra. Quando você volta, ainda jovem e saudável, seus pais já morreram, seu cônjuge está no asilo e seus filhos terminaram a pós-graduação.

Você já viu a cena acima em várias matérias da SUPER - e também no filme Interestelar, de Christopher Nolan. Ela é um jeito clichê e muito eficiente de explicar uma das consequências da Teoria da Relatividade de Albert Einstein: o tempo passa diferente para quem está em movimento. Se a nave atingisse, por exemplo, $92 \%$ da velocidade da luz, cada 1 minuto passado em seu interior corresponderia a 2 minutos e 39 segundos terráqueos (quem quiser fazer essa conta curiosa pode usar uma calculadora relativística).

"Legal", você dirá, "ainda bem que o motorista do meu ônibus alcança só $10 \%$ da velocidade da luz. É o suficiente para eu achar que vou morrer quando alguém dá o sinal em cima da hora, mas não vai me impedir de ver meus filhos crescerem, certo?" Errado.

Às vezes a relatividade afeta sua vida na prática. E você só não percebe porque a engenharia já deu um jeito no problema. É o caso do Waze, do Uber e dos demais aplicativos que dependem do GPS para funcionar.

É o seguinte: a Terra tem 12,7 mil quilômetros de diâmetro, e dá uma volta em torno de si mesma a cada 24 horas. Se você fizer as contas, descobrirá que alguém que está de pé na linha do Equador gira a 1,6 mil km/h (os físicos da UFRGS explicam melhor aqui).

Mantenha isso em mente, e vamos partir para um exercício mental: imagine que há uma pessoa vivendo em um buraco muito, muito fundo - tão fundo que ela esteja consideravelmente mais perto do núcleo do planeta que uma pessoa normal, do tipo que vive na superfície. Esse homem das cavernas também está girando, mas mais devagar, porque está mais perto do centro da esfera. Pelo mesmo motivo que um carro de Fórmula 1 ultrapassa o outro quando faz as curvas por dentro, mais fechadas - mesmo que ele não esteja de fato mais rápido que o oponente. Se nosso homem da caverna profunda está se movendo mais devagar, dizem as equações de Einstein, isso significa que o tempo está passando um bocado (um bocadinho bem pequeno mesmo) mais rápido para ele do que para você. Um mastodontilhão de frações de milésimos de segundo. Uma diferença imperceptível, mas ainda é uma diferença.

Agora vamos fazer o exercício oposto: é o caso de um satélite geoestacionário que está na órbita da Terra, a 36 mil quilômetros de altitude, mas gira em torno de nós sempre usando um ponto fixo na superfície do planeta como referência. Ele é como um Fórmula 1 azarado, que está fazendo a curva muito, mas muito por fora. Por causa disso, ele precisa girar bem mais rápido para acompanhar o nosso ritmo aqui embaixo. Se ele está mais rápido, o tempo, para ele, passa mais devagar. Em relação a nós, ele é o oposto do Fred Flintstone lá embaixo.

Os satélites que fazem o GPS funcionar flutuam mais baixo - "só" 20 mil km - mas completam duas órbitas diárias em torno da Terra. Ou seja: estão bem mais rápidos que 
nossos $1,6 \mathrm{mil} \mathrm{km} / \mathrm{h}$ - cerca de $14 \mathrm{mil} \mathrm{km} / \mathrm{h}$. Por causa disso, o tempo passa mais devagar para eles do que para nós. Para ser mais preciso, 7 microssegundos de atraso diário (essa conta, ainda bem, um físico chamado Neil Ashby já fez para nós).

Além dessa, há outra variável: ele está mais distante da área de influência do campo gravitacional da Terra. Como a gravidade distorce o espaço e o tempo, também é preciso levar em consideração a diferença da atuação dessa força aqui na superfície e lá no alto. Faça mais essa conta e você descobrirá que o tempo, para o satélite, está passando 45 microssegundos mais rápido todos os dias. Subtraia esses dois números (45 e -7) e você terá um delay de 38 microssegundos a cada 24 horas entre o GPS e a Terra.

Os receptores de GPS, como seu celular, calculam a própria posição na Terra cruzando informações fornecidas por no mínimo três dos 24 satélites da rede. $O$ resultado é uma precisão de até $10 \mathrm{~m}$. Mas se o tempo estiver passando em velocidades diferentes aqui na superfície e a 20 mil km de altitude, essa diferença de frações de segundo, antes discreta, vai se acumular o suficiente para se tornar perceptível na escala temporal humana. E a sua posição, com o passar dos dias, será calculada com distorções cada vez mais graves.

A solução para isso é colocar os relógios atômicos que comandam os satélites para rodar mais devagar, compensando a distorção. $E$ ensinar o celular a fazer contas usando a Teoria da Relatividade para evitar erros. Agora você já sabe porque a bateria acaba tão rápido quando o localizador está ativado: haja caloria para seguir o raciocínio do maior gênio da história da Física.

Fonte: Revista Super Interessante - Blog Super Novas. Disponível em: https://super. abril.com.br/blog/supernovas/seu-celular-mastiga-formulas-de-einstein-para-o-wazefuncionarl 


\section{ANEXO C - Infográfico Funcionamento do GPS}

\section{Como funciona}

O Sistema de Posicionamento Global (GPS) permite conhecer a posição de um objeto em qualquer parte do mundo.

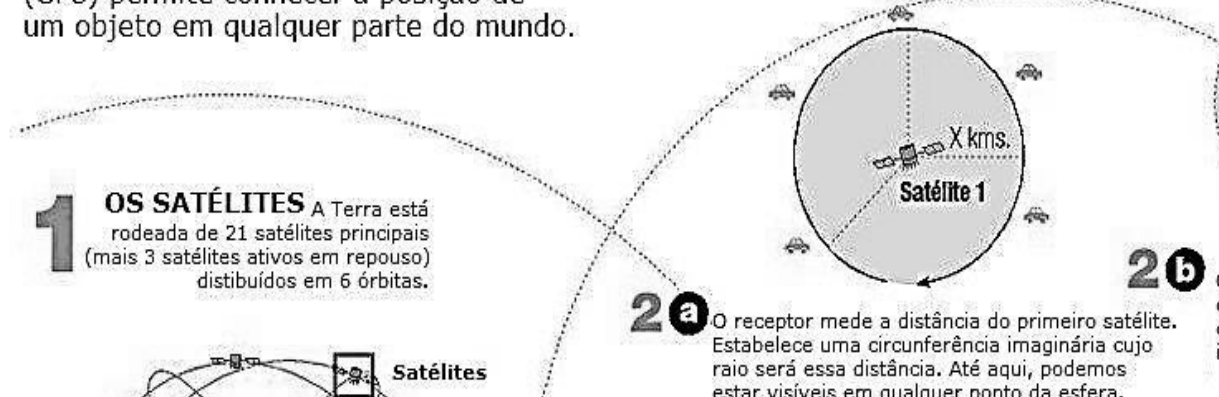

A TRIANGULAÇÃO o sistema GPS se baseia na medição da distância existente
entre o receptor e ao menos 3 satélites

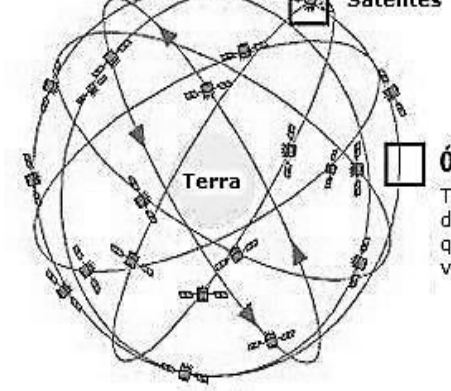

estar visiveis em qualquer ponto da esfera.

O receptor toma agora a distância que separa do satélite 2 e forma uma nova circunferência. Nossa posição estará na intersecção de ambas as esferas.

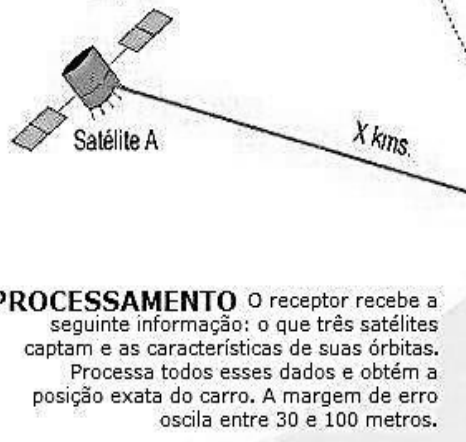

um período de rotação de 12 horas, o que permite que haja de 5 a 8 satélites

O PROCESSAMENTO o receptor recebe a seguinte in Processa todos esses dados e obtém a oscila entre 30 e 100 metros.

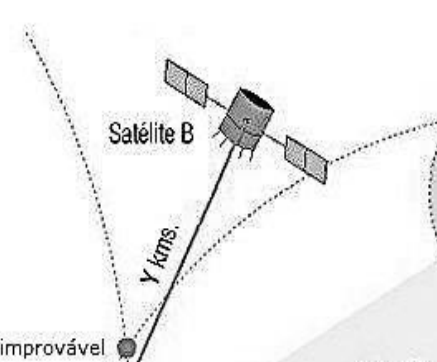$$
\text { ing }
$$

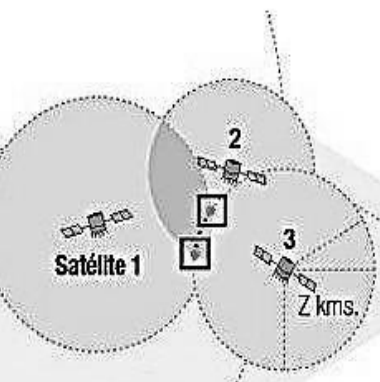

20 O terceiro satélite cria uma nova esfera que corta em dois pontos a intersecção resultante das outras duas. Nossa posição real está em um ponto, já que o outro fica descartado por ser uma localização improvável por estar longe da superfície terrestre.

NOTA: O receptor está projetado para receber sinais de 3 satélites. Quanto Mais sinais captar, mais preciso será o cálculo 


\section{ANEXO D - Massa e Energia}

\section{Massa e Energia}

Muita gente gosta de tomar aquele copão de chocolate em frente da televisão. Quente no friozinho e geladão no calor uma caneca sempre vai bem.

Uma caneca típica de chocolate tem mais ou menos $200 \mathrm{ml}$, como possui densidade próxima da água, o chocolate na caneca tem massa de mais ou menos 200g. O chocolate possui muita energia química facilmente aproveitada pelo corpo e é por isso que é considerado um energético eficiente quando estamos estudando ou praticando esportes.

Contudo, o chocolate não possui somente energia em suas ligações químicas. Pela relatividade, a sua própria massa pode ser transformada em energia! (Na verdade a massa de qualquer coisa!).

Segundo a relatividade, esses $200 \mathrm{~g}$ de chocolate podem ser convertidos em energia, pois $E=m c^{2}$, ou seja, a massa de alguma coisa pode se transformar em energia, mas quanto? É simples, vamos lá:

$$
\begin{aligned}
& \mathrm{m}=200 \mathrm{~g}=0,2 \mathrm{~kg}=2 \cdot 10^{-1} \mathrm{~kg} \\
& \mathrm{c}^{2}=\left(3 \cdot 10^{8} \mathrm{~m} / \mathrm{s}\right)^{2}=9 \cdot 10^{16} \mathrm{~m}^{2} / \mathrm{s}^{2}
\end{aligned}
$$

Então:

$$
\begin{aligned}
& E=m \cdot c^{2}=2 \cdot 10^{-1} \mathrm{~kg} \times 9 \cdot 10^{16} \mathrm{~m}^{2} / \mathrm{s}^{2} \\
& E=1,8 \cdot 10^{16} \mathrm{~J} \\
& E=18000000000000000 \mathrm{~J}
\end{aligned}
$$

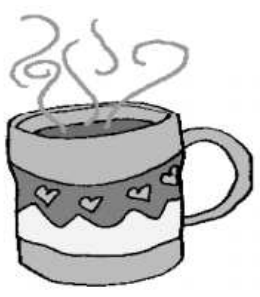

É uma quantidade muito grande de energia não acha?

Vamos supor que utilizássemos essa energia para manter ligado um aparelho de TV de aproximadamente $100 \mathrm{~W}$. Por quanto tempo a TV funcionaria?

Fazendo as contas:

$\begin{aligned} P=\frac{\Delta E}{\Delta t} \longrightarrow \Delta t=\frac{\Delta E}{P} \longrightarrow \quad \longrightarrow \quad \Delta t & =\frac{1,8 \cdot 1016 \mathrm{~J}}{10^{2} J s^{-1}} \\ \Delta t & =1,8 \cdot 10^{14} \text { segundos }\end{aligned}$

Só para termos uma ideia de quanto tempo é isso, um ano tem 365 dias, cada dia tem 24 horas e cada hora tem 3600 segundos. Então:

1 ano $=365 \times 24 \times 3600=31536000$ segundos $\longrightarrow 1$ ano $=3,2 \cdot 10^{7} \mathrm{~s}$

Usando uma regra simples de proporcionalidade, teremos:

$\begin{array}{cc}1 \text { ano } & 3,2 \cdot 10^{7} \mathrm{~s} \\ \Delta \mathrm{t} \text { anos } & 1,8 \cdot 10^{14} \mathrm{~s}\end{array}$

Portanto $\Delta t=5625000$ de anos, ou seja, quase 6 bilhões de anos!

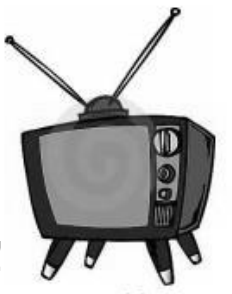

Se a TV durasse tanto tempo, poderia ficar ligada por quase 6 bilhões de anos com a energia de uma simples caneca de chocolate de $200 \mathrm{~g}$, mais ou menos a idade do planeta Terra! 


\section{ANEXO E -A Energia Nuclear e a Bomba Atômica}

\section{A Energia Nuclear e a Bomba Atômica}

Durante a Segunda Guerra Mundial, em agosto de 1945, os americanos bombardearam Hiroshima e Nagasaki, duas cidades japonesas, estreando de forma cruel uma nova tecnologia: a explosão de bombas de fissão.

Por que uma bomba atômica tem um poder tão destruidor? De onde vem tanta energia? Tudo se explica pela equivalência massa-energia.

Se somarmos a massa dos núcleons separados, veremos que sempre se obtém um valor maior que a massa total do núcleo.

Essa diferença na massa $\Delta m=m$ núcleons $-m_{\text {núcleo }}$ é conhecida como "defeito de massa".

Mas onde foi parar a massa que está faltando? A soma das partes não deveria ser igual ao todo?

$\mathrm{Na}$ verdade, não está faltando nada. A diferença de massa fica armazenada, na forma de uma energia potencial $\Delta E=\Delta m . c^{2}$, nas ligações entre os núcleons e, por isso mesmo, chamada de "energia de ligação". Isso está plenamente de acordo com a equivalência massa-energia.

Quando ocorre fissão (ou quebra) de um núcleo atômico, essa energia pode ser liberada. Se, por exemplo, bombardeamos um núcleo de urânio com nêutrons, ele se quebra em duas partes mais leves e libera energia. A equação que mostra o fenômeno é:

$$
{ }_{92}^{235} \mathrm{U} \rightarrow{ }_{54}^{140} \mathrm{Xe}+{ }_{38}^{94} \mathrm{Sr}+{ }_{0}^{1} \mathrm{n}+{ }_{0}^{1} \mathrm{n}+\Delta \mathrm{E}
$$

Note que teremos dois novos nêutrons liberados e eles podem colidir com outros átomos de urânio, ainda íntegros, provocando nova fissão e assim por diante. Essa reação em cascata desencadeia um processo violento de liberação de energia. Na equação anterior, para cada átomo de urânio fissurado temos a liberação de $\Delta \mathrm{E}=\Delta \mathrm{m} \cdot \mathrm{c}^{2}=200 \mathrm{Mev}\left(1 \mathrm{Mev}=1,6 \cdot 10^{-13} \mathrm{~J}\right)$. Imagine todos os átomos liberando essa energia ao mesmo tempo, o montante final será enorme.

A Bomba de Hiroshima, Little Boy, possuía $64 \mathrm{~kg}$ de Urânio, dos quais apenas $700 \mathrm{~g}$ sofreu fissão nuclear. Desses $700 \mathrm{~g}$, apenas $0,7 \mathrm{~g}$ virou energia!

Fonte: http://atp.usp.br:9080/rid=1LRSXM3P6-29LTCH8-XX/REA.4.4.1.pdf

\section{Atividade}

Como exercício, calcule aproximadamente quantos joules de energia foram liberados pela Little Boy sobre Hiroshima. Quantos átomos de Urânio sofreram fissão aproximadamente? Você acha muito? Quantos átomos possui uma caneca de chocolate quente? (dica: use o número de Avogadro e considere o chocolate como água, $\mathrm{H}_{2} \mathrm{O}$, para facilitar. Não tenha dúvida, pesquise!) 